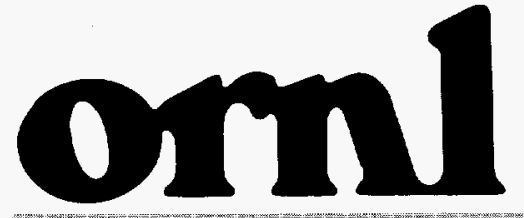

OAK RIDGE NATIONAL LABORATORY

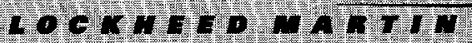

AECEIVED JUN 211996

OSTI
C. W. Forsberg

R. B. Pope

R. C. Ashline

M. D. DeHart

K. W. Childs

J. S. Tang 
This report has been reproduced directly from the best available copy.

Available to DOE and DOE contractors from the Office of Scientific and Technical Information, P.O. Box 62, Oak Ridge, TN 37831; prices available from (615) 576-8401, FTS 626-8401.

Available to the public from the National Technical Information Service, U.S. Department of Commerce, 5285 Port Royal Rd., Springfield, VA 22161.

This report was prepared as an account of work sponsored by an agency of the United States Government. Neither the United States Government nor any agency thereof, nor any of their employees, makes any warranty, express or implied, or assumes any legal liability or responsibility for the accuracy, completeness, or usefulness of any information, apparatus, product, or process disclosed, or represents that its use would not infringe privately owned rights. Reference herein to any specific commercial product, process, or service by trade name, trademark, manufacturer, or otherwise, does not necessarily constitute or imply its endorsement, recommendation, or favoring by the United States Government or any agency thereof. The views and opinions of authors expressed herein do not necessarily state or reflect those of the United States Government or any agency thereof. 


\section{DISCLAIMER}

Portions of this document may be illegible in electronic image products. Images are produced from the best available original document. 


\title{
DUSCOBS-A DEPLETED-URANIUM SILICATE BACKFILL FOR TRANSPORT, STORAGE, AND DISPOSAL OF SPENT NUCLEAR FUEL
}

\author{
C. W. Forsberg \\ R. B. Pope \\ R. C. Ashline \\ Chemical Technology Division \\ Oak Ridge National Laboratory" \\ Oak Ridge, Tennessee 37831 \\ Tel: (423) 574-6783 \\ Fax: (423) 574-3431 \\ E-mail: forsbergcw@ornl.gov \\ M. D. DeHart \\ K. W. Childs \\ J. S. Tang \\ Computational Physics and Engineering Division \\ Oak Ridge National Laboratory \\ Oak Ridge, Tennessee 37831
}

November 30, 1995

Work sponsored by:

Office of Technology Development (DOE/EM-50)

U.S. Department of Energy

*Managed by Lockheed Martin Energy Systems, Inc., under contract DE-AC05-84OR21400 for the U.S. Department of Energy. 



\section{CONTENTS}

LIST OF FIGURES $\ldots \ldots \ldots \ldots \ldots \ldots \ldots \ldots \ldots \ldots \ldots \ldots \ldots \ldots \ldots \ldots \ldots \ldots \ldots \ldots \ldots$

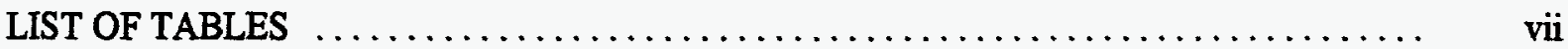

ACRONYMS AND ABBREVIATIONS $\ldots \ldots \ldots \ldots \ldots \ldots \ldots \ldots \ldots \ldots \ldots \ldots \ldots \ldots \ldots \ldots$

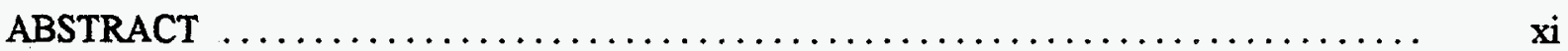

EXECUTIVE SUMMARY $\ldots \ldots \ldots \ldots \ldots \ldots \ldots \ldots \ldots \ldots \ldots \ldots \ldots \ldots \ldots \ldots \ldots \ldots \ldots \ldots \ldots$

1. INTRODUCTION $\ldots \ldots \ldots \ldots \ldots \ldots \ldots \ldots \ldots \ldots \ldots \ldots \ldots \ldots \ldots \ldots \ldots \ldots \ldots \ldots$

2. MECHANICAL DESCRIPTION OF THE DUSCOBS CONCEPT $\ldots \ldots \ldots \ldots \ldots \ldots$

3. URANIUM SILICATE GLASSES $\ldots \ldots \ldots \ldots \ldots \ldots \ldots \ldots \ldots \ldots \ldots \ldots \ldots \ldots$

4. TRANSPORTATION AND STORAGE $\ldots \ldots \ldots \ldots \ldots \ldots \ldots \ldots \ldots \ldots \ldots \ldots \ldots$

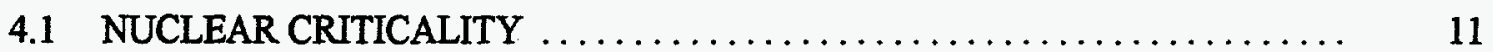

4.2 RADIATION SHIELDING AND TRANSPORT CASK DESIGN $\ldots \ldots \ldots \ldots \ldots .12$

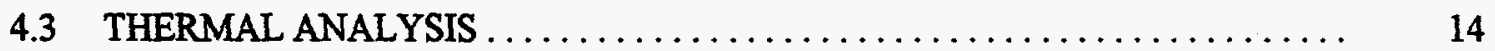

4.4 STRUCTURAL INTEGRITY $\ldots \ldots \ldots \ldots \ldots \ldots \ldots \ldots \ldots \ldots \ldots \ldots \ldots \ldots \ldots \ldots \ldots \ldots \ldots$

5. REPOSITORY BENEFITS AND CONSIDERATIONS $\ldots \ldots \ldots \ldots \ldots \ldots \ldots \ldots \ldots$

5.1 REDUCED RADIONUCLIDE RELEASE RATE FROM WASTE PACKAGE .. 19

5.1.1 Mechanisms of Degradation of SNF in a Geological Repository ......... 19

5.1.1.1 Oxidizing Groundwater Impacts on SNF .............. 19

5.1.1.2 Reducing Groundwater Impacts on SNF ............ 20

5.1.2 DUSCOBS Chemical Effects on Repository Performance ........... 20

5.1 .3 DUSCOBS Physical Effects on Repository Performance $\ldots \ldots \ldots \ldots \ldots .21$

5.2 AVOIDANCE OF NUCLEAR CRITICALITY $\ldots \ldots \ldots \ldots \ldots \ldots \ldots \ldots \ldots$

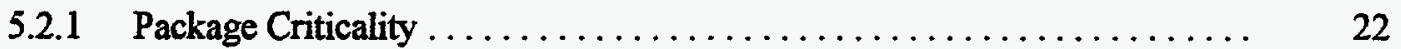

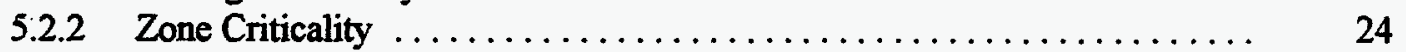

5.2.2.1 Mechanisms of Zone Criticality .................. 24

5.2.2.2 Fissile Content of SNF ...................... 28

5.2.2.3 Occurrence of Nuclear Criticality Based on Geological History . $\quad 30$

5.2.2.4 Impacts of Plutonium . ................... 31 


\section{CONTENTS (continued)}

5.3 REDUCED RADIATION INTERACTION WTTH WASTE PACKAGE, WASTE PACKAGE CONTENT, AND NEAR-FIELD GEOLOGY ............ 33

5.4 CONTROLLED INTERNAL PACKAGE TEMPERATURE $\ldots \ldots \ldots \ldots \ldots \ldots . . \ldots$

5.5 REPOSITORY DESIGN TRADEOFF CONSIDERATIONS $\ldots \ldots \ldots \ldots \ldots \ldots . . \ldots$

6. MANAGEMENT OF DU $\ldots \ldots \ldots \ldots \ldots \ldots \ldots \ldots \ldots \ldots \ldots \ldots \ldots \ldots \ldots \ldots \ldots \ldots \ldots$

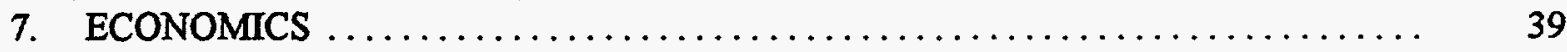

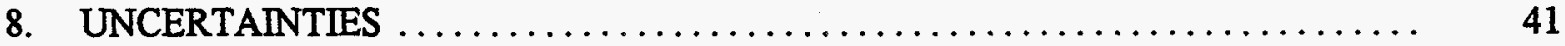

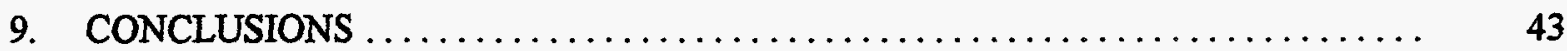

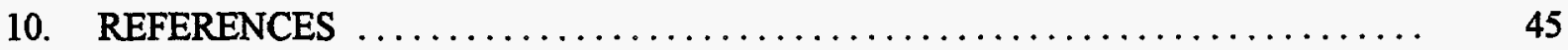

Appendix A: $\quad$ CHARACTERISTICS OF MPC AND LWR SNF $\ldots \ldots \ldots \ldots \ldots \ldots$ A-1

Appendix B: $\quad$ CRITICALITY AND SHIELDING ANALYSIS OF DUSCOBS $\ldots \ldots \ldots$ B-1

Appendix C: $\quad$ THERMAL ANALYSES OF DUSCOBS $\ldots \ldots \ldots \ldots \ldots \ldots \ldots \ldots$ C-1

Appendix D: $\quad$ FINAL ENRICHMENT DISTRIBUTION OF LWR SNF $\ldots \ldots \ldots \ldots$ D-1

Appendix E: $\quad$ FUTURE WORK $\ldots \ldots \ldots \ldots \ldots \ldots \ldots \ldots \ldots \ldots \ldots \ldots \ldots \ldots \ldots \ldots \ldots \ldots \ldots$ 


\section{LIST OF FIGURES}

Fig. $1 \quad$ Large MPC for 21 PWR SNF assemblies ....................... 2

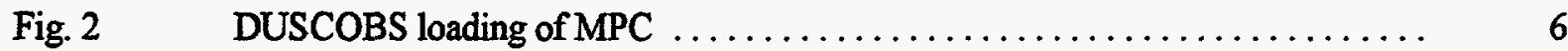

Fig. 3 Major heat transfer paths in the MPC and other SNF packages ............ 17

Fig. $4 \quad$ Alternative repository criticality scenarios $\ldots \ldots \ldots \ldots \ldots \ldots \ldots \ldots \ldots, 23$

Fig. 5 Natural and man-made formation of uranium ore deposits .............. 26

Fig. 6 Minimum spherical critical volumes as functions of ${ }^{235} \mathrm{U}$ enrichment in homogeneous and heterogeneous hydrogen-moderated systems $\ldots \ldots \ldots \ldots . \quad 27$

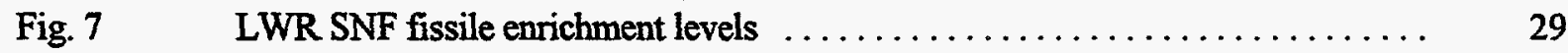

Fig. 8 Quantity of DU $\left(0.2 \%{ }^{235} \mathrm{U}\right)$ required per metric ton of SNF heavy metal for different final repository enrichment levels . . . . . . . . . . . . . . 32

Fig. B.1 Model for shielding calculations $\ldots \ldots \ldots \ldots \ldots \ldots \ldots \ldots \ldots \ldots \ldots$, B-10

Fig. C.1 $\quad$ MPC interior-basket and glass bead filler $\ldots \ldots \ldots \ldots \ldots \ldots \ldots \ldots, C-6$

Fig. C.2a Temperature distribution in MPC (fuel rods not included in model) $\ldots \ldots \ldots$. C-7

Fig. C.2b Temperature distribution in MPC (fuel rods not included in model), 20 rod

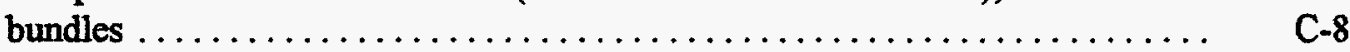

Fig. C.2c Temperature distribution in MPC (fuel rods not included in model), 16 rod bundles $\ldots \ldots \ldots \ldots \ldots \ldots \ldots \ldots \ldots \ldots \ldots \ldots \ldots \ldots \ldots \ldots \ldots \ldots \ldots \ldots, \quad \mathrm{C}-9$

Fig. C.3 Fuel rod and surrounding glass beads $\ldots \ldots \ldots \ldots \ldots \ldots \ldots \ldots \ldots, \mathrm{C}-10$

Fig. C.4a Temperature distribution in MPC (glass-bead conductivity modified to account for fuel rods), 21 rod bundles $\ldots \ldots \ldots \ldots \ldots \ldots \ldots \ldots \ldots \ldots, \mathrm{C}-12$

Fig. C.4b Temperature distribution in MPC (glass-bead conductivity modified to account

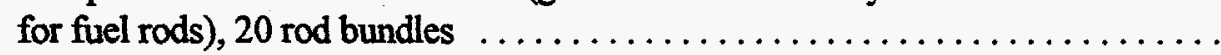




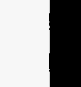




\section{LIST OF TABLES}

Table 1 Component volumes $\left(\mathrm{m}^{3}\right)$ within an $\mathrm{MPC} \ldots \ldots \ldots \ldots \ldots \ldots \ldots \ldots \ldots \ldots \ldots$

Table 2 Example glass compositions . . . . . . . . . $9 \ldots \ldots \ldots \ldots \ldots \ldots \ldots \ldots$

Table 3 Multiplication constant $k_{\text {eff }}$ (measure of criticality safety) for the large MPC loaded with fresh PWR nuclear fuel $\ldots \ldots \ldots \ldots \ldots \ldots \ldots \ldots \ldots \ldots \ldots, \quad 12$

Table 4 Predicted dose rates for 21-element MPCs in spent fuel shipping casks . . . . ... 13

Table 5 Estimated mass of key components of current large MPC/cask system ........ 15

Table 6 Estimated mass of key components of large MPC/cask system modified to

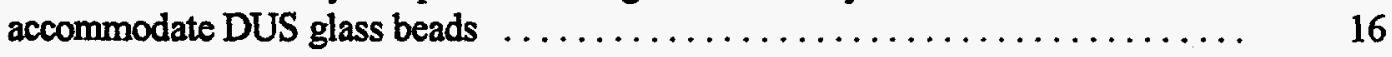

Table 7 Neutron multiplication factor $\left(k_{e f f}\right)$ for fully loaded MPCs in which all boron has

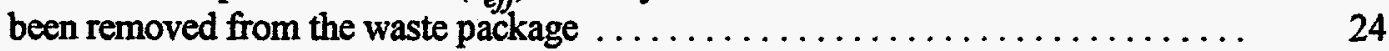

Table 8 Average MPC enrichments (wt \%) for different PWR SNF enrichment levels and different uranium density backfill materials with $0.2 \%{ }^{235} \mathrm{U} \ldots \ldots \ldots \ldots \ldots \ldots . . \ldots 1$

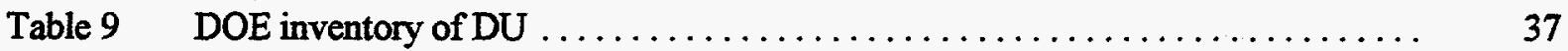

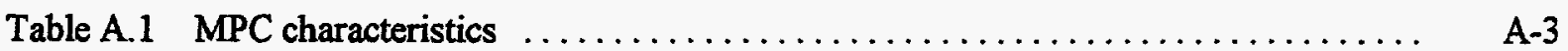

Table A.2 Reference PWR nuclear fuel assembly . . . . . . . . . . . . .

Table B.1 Westinghouse $17 \times 17$ fuel assembly design specifications $\ldots \ldots \ldots \ldots \ldots \ldots \ldots$ B-5

Table B.2 Assumed reactor conditions for depletion calculations $\ldots \ldots \ldots \ldots \ldots \ldots \ldots$ B-6

Table B.3 Composition of DU silicate glass $\ldots \ldots \ldots \ldots \ldots \ldots \ldots \ldots \ldots \ldots \ldots \ldots \ldots \ldots$

Table B.4 Results of criticality calculations for $3.75 \mathrm{wt} \%$ fresh fuel $\ldots \ldots \ldots \ldots \ldots \ldots \ldots$

Table B.5 Results of criticality calculations for $5.00 \mathrm{wt} \%$ fresh fuel $\ldots \ldots \ldots \ldots \ldots \ldots \ldots$ B-8

Table B.6 Results of cask shielding calculations of neutron dose $\ldots \ldots \ldots \ldots \ldots \ldots \ldots$ B-11

Table B.7 Results of cask shielding calculations of primary gamma-ray dose . . . . . . . B-11

Table B.8 Results of cask shielding calculations of secondary gamma-ray dose . . . . . . B-12

Table B.9 Total dose estimated for various casks configurations . . . . . . . . . . . B-13

Table B.10 Nominal MPC shield component masses $\ldots \ldots \ldots \ldots \ldots \ldots \ldots \ldots \ldots \ldots$ B-15

Table B.11 Modified MPC shield component masses . . . . . . . . . . . . . . . . . B-16

Table C.1 Axial variation in power along a fuel rod $\ldots \ldots \ldots \ldots \ldots \ldots \ldots \ldots \ldots \ldots \ldots$

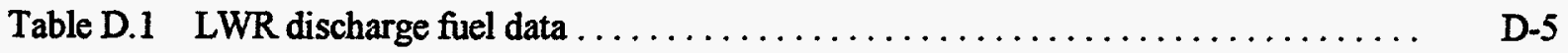

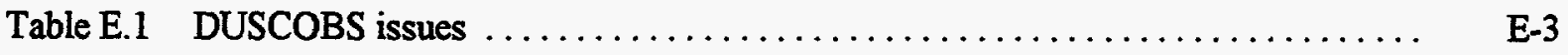




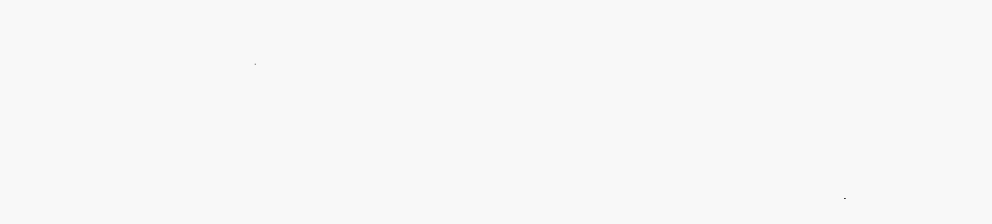




\section{ACRONYMS AND ABBREVIATIONS}

1-D One-dimensional

3-D Three-dimensional

AEF Average energy at which fission occurs

AFR Away from reactor

ANS American Nuclear Society

ANSI American Nuclear Standards Institute

BWR Boiling-water reactor

DOE U.S. Department of Energy

DU Depleted uranium

DUS Depleted uranium silicate

DUSCOBS Depleted Uranium Silicate COntainer Backfill System

HLW High-level waste

IAEA International Atomic Energy Agency

LWR Light-water reactor

MPC Multipurpose canister

MTIHM Metric tons of initial heavy metal

MTU Metric tons uranium

MWd Megawatt-days

NRC U.S. Nuclear Regulatory Commission

ORGENTRE Oak Ridge Waste GENeration and TREatment

PWR Pressurized-water reactor

SNF Spent nuclear fuel

U.S. United States 



\title{
DUSCOBS-A DEPLETED-URANIUM SILICATE BACKFILL FOR TRANSPORT, STORAGE, AND DISPOSAL OF SPENT NUCLEAR FUEL
}

\author{
C. W. Forsberg, R. B. Pope, R. C. Ashline, M. D. DeHart \\ K. W. Childs, and J. S. Tang
}

\begin{abstract}
A Depleted Uranium Silicate COntainer Backfill System (DUSCOBS) is proposed that would use small, isotopically-depleted uranium silicate glass beads as a backfill material inside storage, transport, and repository waste packages containing spent nuclear fuel (SNF). The uranium silicate glass beads would fill all void space inside the package including the coolant channels inside SNF assemblies.

Based on preliminary analysis, the following benefits have been identified. DUSCOBS improves repository waste package performance by three mechanisms. First, it reduces the radionuclide releases from SNF when water enters the waste package by creating a local uranium silicate saturated groundwater environment that suppresses (a) the dissolution and/or transformation of uranium dioxide fuel pellets and, hence, (b) the release of radionuclides incorporated into the SNF pellets. Second, the potential for long-term nuclear criticality is reduced by isotopic exchange of enriched uranium in SNF with the depleted uranium (DU) in the glass. Third, the backfill reduces radiation interactions between SNF and the local environment (package and local geology) and thus reduces generation of hydrogen, acids, and other chemicals that degrade the waste package system. In addition, the DUSCOBS improves the integrity of the package by acting as a packing material and ensures criticality control for the package during SNF storage and transport. Finally, DUSCOBS provides a potential method to dispose of significant quantities of excess DU from uranium enrichment plants at potential economic savings. DUSCOBS is a new concept. Consequently, the concept has not been optimized or demonstrated in laboratory experiments.
\end{abstract}





\section{EXECUTIVE SUMMARY}

\section{INTRODUCTION}

It is proposed that small, depleted uranium silicate (DUS) glass beads be used as a backfill material inside storage, transport, and repository waste packages containing light-water reactor (LWR) spent nuclear fuel (SNF). The use of DUS glass beads has the potential to improve repository performance, improve SNF transport and storage, dispose of excess depleted uranium (DU), and reduce system costs. A mechanical description of the Depleted Uranium Silicate COntainer Backfill System (DUSCOBS) is provided followed by descriptions of how DUSCOBS performs its functions. DUSCOBS is a new concept. This report is a first description of DUSCOBS, its potential advantages, and the associated uncertainties.

For the study herein, DUSCOBS was applied to the proposed U.S. Department of Energy (DOE) multipurpose canister (MPC) system. The MPC is an inner container for SNF storage containers, transport casks, and geological disposal packages. DUSCOBS is applicable to (1) alternative MPC designs and (2) other SNF transport, storage, and repository systems.

\section{MECHANICAL DESCRIPTION}

The multipurpose canister (MPC) or waste package would first be loaded with SNF. Then, the package would be backfilled with DUS glass beads. The beads would be sufficiently small-similar to fine sand in size-to fill the coolant channels between fuel rods. After the package has been completely filled, the package would be sealed. The sealed MPC then could be held in a storage cask, loaded into a compatible transport cask for shipment, and finally loaded and sealed into a disposal cask at the repository. Several uranium compounds could be used as a backfill material including uranium silicate glass, other uranium silicates, and uranium dioxide $\left(\mathrm{UO}_{2}\right)$. Based on preliminary engineering and geochemical considerations, DUS glass was chosen.

\section{REPOSITORY BENEFITS}

The first potential benefit for repository design, licensing, and operation would be lower radionuclide release rates from the waste package over geological time. LWR SNF consists of bundled sets of Zircaloy tubes. Each tube contains $\mathrm{UO}_{2}$ fuel pellets. Fission products and actinides are primarily incorporated within the $\mathrm{UO}_{2}$ fuel pellets. The release of fission products and actinides from the SNF is limited by (1) the alteration of the $\mathrm{UO}_{2}$ fuel matrix to more thermodynamically stable and less soluble compounds such as 
uranium silicates and (2) the dissolution of the matrix. The alteration process allows dissolution of soluble fission products and formation of actinide colloids. Uranium dioxide alteration and dissolution are limited by the solubility and leachability of the uranium. Backfilling the waste package with appropriate DUS glass creates a packaging environment saturated in uranium. This environment slows the alteration and dissolution of the $\mathrm{UO}_{2}$ in the fuel elements and, hence, slows the release of the radionuclides incorporated within the $\mathrm{UO}_{2}$. This is analogous to the observation that saturated salt water does not dissolve salt. These effects are enhanced further by the backfill that lowers the hydraulic conductivity within the package compared to packages with no backfill material. This ensures low water-flow rates inside the waste package with lower dissolved radionuclide transport and reduced colloid transport.

The second potential benefit would be the avoidance of nuclear criticality over geological time. LWR SNF contains several fissile materials: ${ }^{235} \mathrm{U},{ }^{239} \mathrm{Pu}$, and other isotopes. In time, fissile materials such as ${ }^{239} \mathrm{Pu}$ decay to ${ }^{235} \mathrm{U}$; thus, most plutonium in the SNF ultimately is converted to ${ }^{235} \mathrm{U}$. As a result, long-term avoidance of nuclear criticality is based on the avoidance of criticality from ${ }^{235} \mathrm{U}$. In a geological environment, chemical neutron poisons (except ${ }^{238} \mathrm{U}$ ) will separate from the uranium, and the uranium may migrate, over time, and redeposit. If the uranium enrichment is sufficiently high, nuclear criticality may. occur. In the ancient Oklo natural reactors in Africa, the uranium enrichment when the reactors shut down was as low as $1.3 \%{ }^{235} \mathrm{U}$. The average fissile enrichment of the LWR SNF inventory in the United States is at $1.47 \%$. The average fissile content of the SNF is expected to increase with time. Long-term nuclear criticality is a possibility based on the geological record. If waste canisters are backfilled with DUS glass ${ }^{235} \mathrm{U}$ content $0.2 \%$ ), uranium in the fuel assemblies will undergo ion exchange with uranium in the glass over time. This ensures that when dissolution occurs, isotopic dilution of the SNF uranium will occur, thus creating a very low-enriched uranium $\left(<1 \%{ }^{235} U\right)$ geological environment in which nuclear criticality is impossible.

The third potential benefit would be lower radiation levels internal and external to the waste package that would, in turn, simplify handling and reduce radiation interactions between waste package and the local environment. The uranium glass has a density between 4.5 and $7 \mathrm{~g} / \mathrm{cm}^{3}$. This density and the uranium in the glass provides good gamma-shielding capabilities. The SNF can be directly exposed to air and water when the package degrades. Radiation interactions with air and water create acids and hydrogen that accelerate package and SNF degradation The glass reduces these interactions by reducing the radiation levels and the void spaces available for air or water in the package. 
In addition to the three primary advantages, two other potential repository benefits are dependent upon the existence of a backfill material-although that material need not be DUS glass.

Assured heat transfer. Heat-transfer analysis indicates that there is no significant difference in peak SNF temperatures with DUSCOBS vs a gas-filled canister; however, there is a higher assurance that excessive SNF temperatures will not occur. The glass beads are expected to have a higher thermal conductivity than does the backfill gas, but the glass beads reduce heat transfer by radiation and gas convection. Preliminary analysis shows that these different factors counterbalance each other. However, radiation heat transfer and convective heat transfer are strongly dependent upon MPC geometry. Over the long term, the MPC will fail. With a gas-filled MPC, the collapsing grid structure and fuel assemblies alter the geometry of the package and its heat transfer. With DUSCOBS, there would be no empty space, general structural collapse could not occur, and the conduction heat-transfer system would not change.

Reduced radionuclide release rate. The backfill (by preventing collapse) maintains the basic geometry of the package. This geometry restrains movement of SNF and crushing of SNF or mechanical dispersion and minimizes potential leaching of radionuclides.

\section{STORAGE AND TRANSPORTATION BENEFITS}

There are benefits to be derived from implementation of this concept for both storage and transportation of the SNF. If it is assumed that the MPCs containing SNF are backfilled with DUS glass beads prior to being sealed, several benefits are derived:

- The need for the metallic DU in the lid of the MPC may be eliminated.

- The amount of gamma-shielding material in the walls of the storage casks and transportation casks can be reduced.

- The neutron shielding materials in the walls of the storage casks and transportation casks may be reduced.

- The need to include burnup credit for criticality safety limits in the MPC/cask is eliminated.

\section{BENEFITS TO DU PROGRAM}

The United States currently has an inventory of more than $400,000 \mathrm{t}$ of DU-most of it stored in the form of uranium hexafluroide $\left(\mathrm{UF}_{6}\right)$ at Oak Ridge, Tennessee; Paducah, Kentucky; and Portsmouth, Ohio. Ultimately, this material must be converted from $\mathrm{UF}_{6}$ to a less hazardous, long-term storage form, and either a use for it must be found, or it must be disposed of. The proposal presented in this report may result in the beneficial, multiprogram use of at least $25 \%$, and potentially much more, of this inventory. 


\section{ECONOMICS}

No economic analysis has been conducted. There are added costs and savings. The costs include manufacture and emplacement of DUS glass beads. Potential savings include: (1) simplified repository licensing with demonstration of improved performance, (2) simplified licensing of the MPC/cask design, and (3) avoidance of costs for disposal of DU.

\section{ENABLING TECHNOLOGIES}

New uranium glasses have been developed with high uranium loadings and low solubilities. The leachability of these glasses is two to three orders of magnitude lower than the requirements for high-level waste glasses. New understanding of LWR SNF degradation with time provides a mechanism to estimate potential reductions in radionuclide release rates from packages with such backfills. It is specifically noted that recent experimental work has begun to demonstrate the evolution of SNF, over geological time, to uranium silicates. This understanding enables the design of optimum DUS glass-bead backfill systems.

\section{UNRESOLVED ISSUES}

A systems approach to address technical tradeoffs and cost is required. There are potential benefits for a DU glass waste package backfill, but these have not been fully quantified nor experimentally verified. There are also other considerations such as impact on repository plans as well as practical approaches to conducting fill operations that have not been evaluated. Detailed analysis of shielding, criticality, heat transfer, and structural behavior of the MPC loaded with DUS glass must be performed. The ability to produce DUS glass, the best formulation of DUS glass, and the desired leach rates of DUS glass to optimize repository performance need to be established. Significant uncertainties remain.

The United States is currently considering packaging SNF into MPCs at reactor sites. MPCs at the reactor site would use transport overpacks for transport to storage and the repository. At the repository site, a repository waste package overpack would be added. The use of the MPC raises other issues with DUSCOBS. For example, glass beads could be added at either the reactor sites or the repository. Operational issues may determine if the DUS glass beads are added at the reactor for transport and storage benefits or at the repository for repository only benefits.

\section{CONCLUSIONS}

The use of DUS glass beads offers potential benefits as a SNF MPC or waste package backfill material. Because the backfill material is contained within the waste package, uncertainties in performance assessment are minimized because the environment is defined. There are potential benefits in terms of repository performance, repository licensing, fuel transport, and fuel storage. There are also uncertainties. 


\section{INTRODUCTION}

A new approach to improve the performance and potentially lower the costs of spent fuel storage, transport, and disposal has been identified. It is called the Depleted Uranium Silicate COntainer Backfill System (DUSCOBS). This report is an initial description of this technology, its potential advantages, the uncertainties, and required work to evaluate its performance.

The United States [U.S. Department of Energy (DOE), 1994] is considering use of a multipurpose canister (MPC) for the storage, transport, and disposal of light-water reactor (LWR) spent nuclear fuel (SNF). DUSCOBS is analyzed in terms of this specific system. DUSCOBS is applicable to (1) alternative MPC designs and (2) other storage, transport, and repository systems.

The MPC (Fig. 1, Appendix A) is a thin-walled, stainless steel container that could be produced in different sizes. As currently envisioned, the MPC would include a DU-metal shield plug in its lid to provide worker radiation protection during handling. A representative MPC would contain 21 pressurized-water reactor (PWR) SNF assemblies. The MPC could be loaded with SNF at the reactor, at an away from reactor (AFR) storage facility, or at the repository. Once loaded, it is intended that the SNF would never be handled again as individual fuel assemblies. The MPC would become an inner container for all future SNF operations.

For SNF storage at the reactor site or an AFR storage facility, the MPC would be placed inside a shielded storage module. A transportation cask would be used to transport the MPC from a reactor or an AFR storage facility to the repository. The MPC would then be placed within a disposal overpack. The MPC and the disposal overpack, which is known as the waste package, would then be placed in a geological repository. The use of the MPC (1) minimizes SNF handling, (2) reduces the potential for radiation contamination, and (3) avoids the need to build multiple baskets to hold SNF during transport, storage and disposal.

Multiple issues are associated with the use of the MPC including short- and long-term nuclear criticality control, radiation shielding, heat loading, and repository performance. It is proposed that the performance of the MPC during storage, transport, and disposal may be improved by addition of depleted-uranium silicate (DUS) glass, in the form of small beads, to the MPC after the MPC is loaded with SNF. The DUS glass beads would fill all empty space in the MPC, including the cooling channels within the SNF assemblies. The chemical, nuclear and physical properties of the glass would be engineered to maximize MPC performance in multiple environments. 


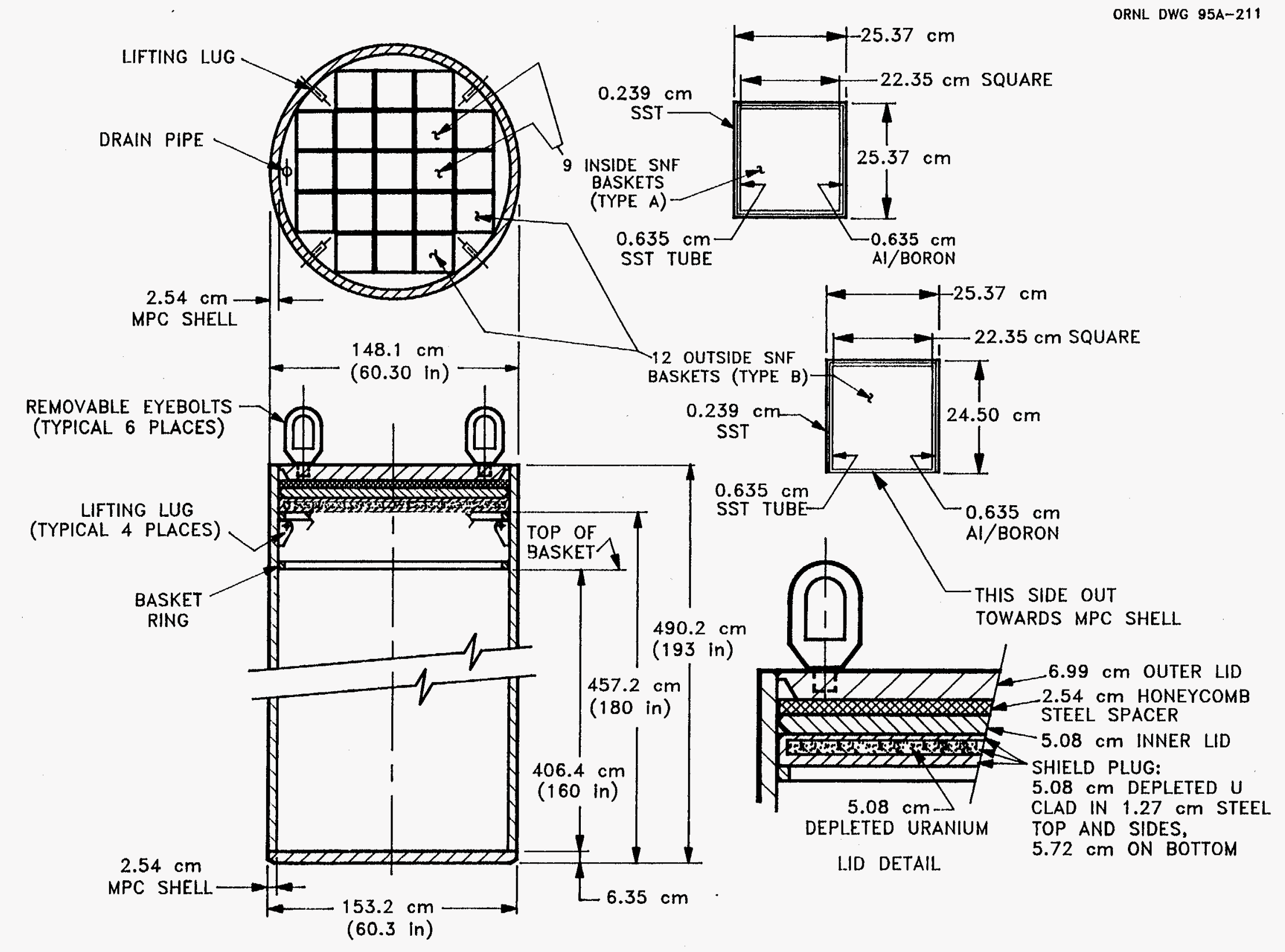

Fig. 1. Large MPC for 21 PWR SNF assemblies. 
A mechanical description of the DUSCOBS as it applies to the MPC system is provided herein. The projected DUS glass characteristics are briefly summarized. Three classes of potential benefits are described: benefits to the design and operation of the MPC storage modules and shipping cask; benefits to the design, performance, assessment, and operation of the SNF repository; and benefits to the disposition of excess DU. Finally, potential economic factors and uncertainties (i.e., unresolved issues) are discussed and recommendations for future action are provided. 



\section{MECHANICAL DESCRIPTION OF THE DUSCOBS CONCEPT}

In the implementation of DUSCOBS, the MPC would first be loaded with SNF (Fig. 2). After SNF is loaded, the MPC would be backfilled with DUS glass beads. Depending upon the loading location, the glass beads may either be loaded while the canister is open or added latter through a small fill hole in the MPC lid. ${ }^{1}$ The beads would be sufficiently small-similar in size to fine sand-to fill the coolant channels between fuel rods. After the package is filled, the MPC would be sealed. One method of filling the MPC is illustrated in Fig. 2.

For a large MPC designed for 21 PWR SNF assemblies, most of the space in the MPC is void space that can be filed with glass beads. The MPC has an internal volume (Appendix A) of $7.9 \mathrm{~m}^{3}$ with the fuel assembly baskets having a solid volume of $1.1 \mathrm{~m}^{3}$. The 21 PWR SNF assemblies have a solid volume (Appendix A) of only $1.6 \mathrm{~m}^{3}$. The fuel assemblies are mostly empty coolant channels (Appendix A). Thus, $5.2 \mathrm{~m}^{3}$ of the $7.9 \mathrm{~m}^{3}$ of internal volume in the 21 PWR assembly loaded MPCs can be filled with beads (Table 1). The fraction of the canister that is void space depends upon the MPC size and fuel type, but in all LWR SNF waste package designs, most of the canister volume is void space (Sadeghi, Pigford, Chambre and Lee, 1990).

Table 1. Component volumes $\left(\mathrm{m}^{3}\right)$ within an MPC

\begin{tabular}{ll}
\hline MPC internal volume & 7.876 \\
MPC fuel baskets & 1.123 \\
MPC free volume & 6.753 \\
PWR SNF solid volume & 1.598 \\
Available volume for glass & 5.155 \\
\hline
\end{tabular}

${ }^{1}$ The method for filling the MPC (loaded with SNF) with DUS glass beads has not been explored; however, it is the view of the authors that a number of alternatives are possible. Trade-off studies and demonstration testing will be required to define the best method for filling the MPC with DUS glass beads. 

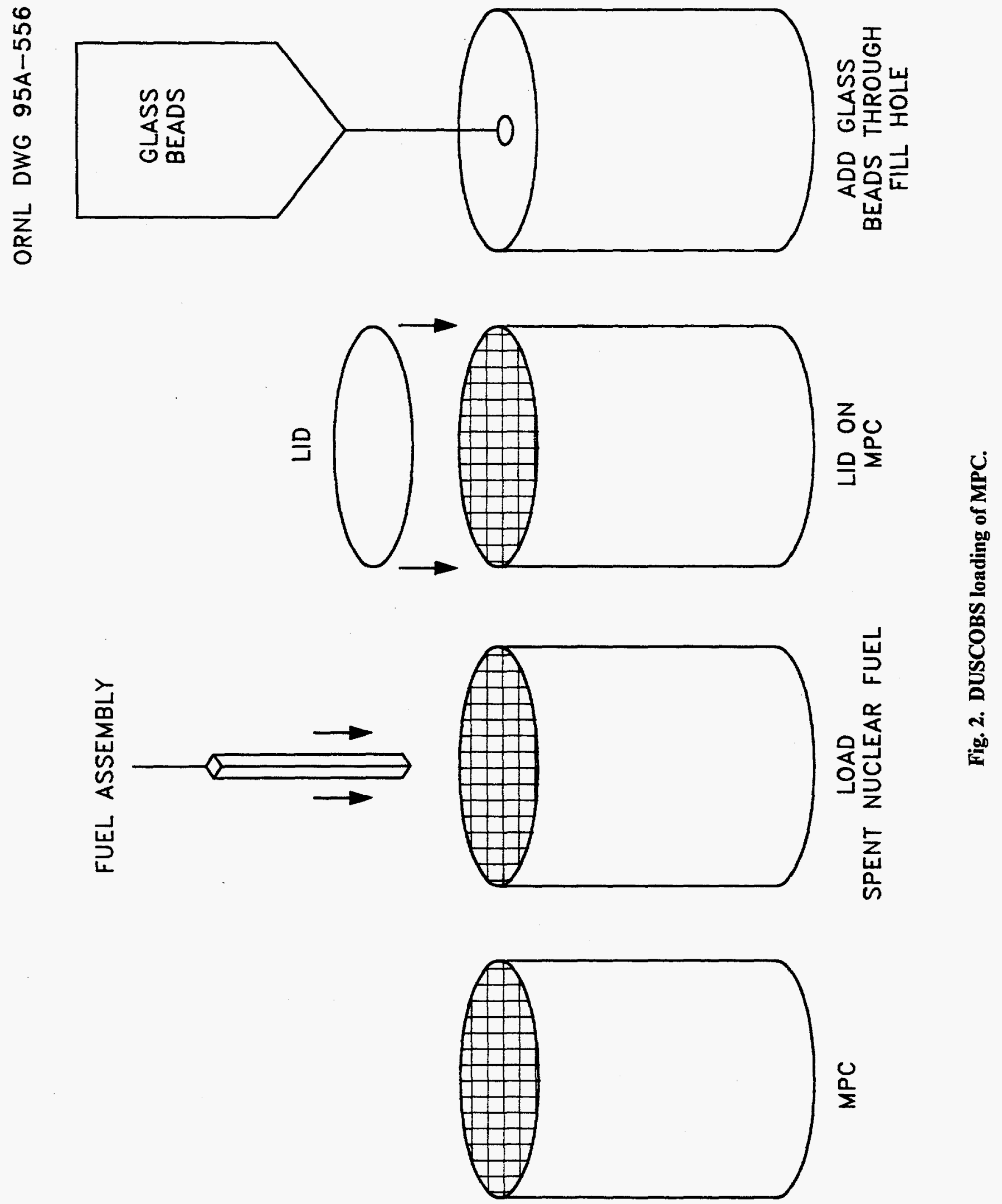
The option exists to place monolithic glass blocks in empty spaces between the square baskets and the outer, round MPC shell (Fig. 1). Glass beads would be typically $65 \%$ glass and $35 \%$ void space, whereas monolithic glass is $100 \%$ glass. This DUS-loading option would provide added shielding within the MPC and reduce external shielding requirements (see Sect. 4.2) while maintaining sufficient DUS within the MPC (see below). In this case, after placement of the monolithic glass blocks in the MPC, the MPC would be loaded with SNF, and the remaining empty void space would be backfilled with DUS glass beads. 



\section{URANIUM SILICATE GLASSES}

There are several choices of uranium silicate backfill materials ranging from uranium borosilicate glasses, to uranium soda lime glasses, to pure uranium silicate. The preferred choice will depend upon complex trade-offs on different performance characteristics and economics. ${ }^{2}$ Table 2 provides the chemical composition of three uranium glasses that have been manufactured (Ramsey 1994; Chakrabarty 1969). It is noteworthy that there is a significant literature on uranium glasses including development of highly loaded uranium glasses for nuclear reactor fuels.

Table 2. Example glass compositions

\begin{tabular}{|c|c|c|c|c|c|c|}
\hline \multirow[b]{3}{*}{ Compound } & \multicolumn{6}{|c|}{ Glass type (density) } \\
\hline & \multicolumn{2}{|c|}{$\begin{array}{c}\text { Loffler } \\
\left(5.0 \mathrm{~g} / \mathrm{cm}^{3}\right)\end{array}$} & \multicolumn{2}{|c|}{$\begin{array}{l}\text { Soda lime } \\
\left(4.1 \mathrm{~g} / \mathrm{cm}^{3}\right)\end{array}$} & \multicolumn{2}{|c|}{ Sodium silicate } \\
\hline & $\mathrm{mol} \%$ & wt $\%$ & $\mathrm{~mol} \%$ & wt $\%$ & $\mathrm{~mol} \%$ & wt $\%$ \\
\hline $\mathrm{Al}_{2} \mathrm{O}_{3}$ & 18.0 & 14.5 & 0.0 & 0.0 & 0.0 & 0.0 \\
\hline $\mathrm{B}_{2} \mathrm{O}_{3}$ & 5.4 & 2.97 & 0.0 & 0.0 & 0.0 & 0.0 \\
\hline $\mathrm{BaO}$ & 2.8 & 3.39 & 0.0 & 0.0 & 0.0 & 0.0 \\
\hline $\mathrm{CaO}$ & 0.0 & 0.0 & 16.1 & 9.6 & 0.0 & 0.0 \\
\hline $\mathrm{Na}_{2} \mathrm{O}$ & 0.0 & 0.0 & 9.6 & 6.3 & 18.3 & 11.2 \\
\hline $\mathrm{PbO}$ & 5.8 & 11.0 & 0.0 & 0.0 & 0.0 & 0.0 \\
\hline $\mathrm{SiO}_{2}$ & 49.4 & 23.45 & 69.8 & 44.2 & 62.1 & 36.8 \\
\hline $\mathrm{UO}_{2}$ & 9.0 & 19.2 & 0.0 & 0.0 & 19.6 & 52.0 \\
\hline $\mathrm{U}_{3} \mathrm{O}_{8}$ & 0.0 & 0.0 & 4.5 & 40.0 & 0.0 & 0.0 \\
\hline $\begin{array}{l}\text { Rare earths } \\
\left.\text { (e.g., } \mathrm{Nd}_{2} \mathrm{O}_{3}\right)\end{array}$ & 9.6 & 25.5 & 0.0 & 0.0 & 0.0 & 0.0 \\
\hline
\end{tabular}

${ }^{2}$ These tradeoff studies have not been undertaken. 
Loffler glass is a borosilicate glass and a relative of conventional high-level waste (HLW) glasses. Loffler glasses, which were developed for optical lenses in the earlier part of this century, are currently being redesigned to incorporate americium and curium within their structures for transport and storage of these materials. The glass is engineered to allow essentially complete recovery of the americium and curium using appropriate chemical processing. The glass has a water leachability about three orders of magnitude lower than that of conventional HLW borosilicate glass. This is noteworthy in terms of long-term durability of the backfill material and the ability to choose glasses with high uranium loadings and any desired solubility over a broad range of properties (see below). Loffler glasses have been loaded up to $30 \mathrm{wt} \%$ uranium dioxide $\left(\mathrm{UO}_{2}\right)$ equivalent.

The soda lime glass is used as bottle glass and for other purposes. Soda lime glasses with uranium loadings up to $50 \mathrm{wt} \% \mathrm{U}_{3} \mathrm{O}_{8}$ equivalent have been made. If desired, various neutron absorbers could be added to this glass.

Simple, three-component uranium glasses (Chakrabarty 1969) have also been made. These were investigated as potential reactor fuels.

One other backfill material deserves special note. This material is $\mathrm{UO}_{2}$ with a theoretical density of $10.96 \mathrm{~g} / \mathrm{cm}^{3}$ (Dean 1973). Uranium dioxide can be fabricated into microspheres by a variety of processes developed for fuel fabrication. Uranium dioxide has several advantages as a backfill material including its high density and well-known characteristics. It has two potential disadvantages. First, its chemical properties can not be modified to optimize SNF leach resistance or other desired characteristics. With glasses, there are a range of chemical and physical characteristics that can be optimized. Second, current fabrication techniques for uranium oxide beads are expensive. High cost may or may not be a barrier for its use as a backfill material. It may be possible to develop low-cost fabrication techniques because there would be no requirement to meet fuel fabrication standards. There are other DUS compounds that are also potential backfill materials. A better understanding of the system is required before definitive decisions are made. 


\section{TRANSPORTATION AND STORAGE}

DUSCOBS offers several potential advantages for transport and storage of SNF. Four areas were investigated: package heat transfer, nuclear criticality, radiation shielding, and structural integrity.

\subsection{NUCLEAR CRITICALITY}

Storage and transport cask design must ensure that nuclear criticality can not occur. Existing regulations require that a set of highly conservative assumptions are used in such determinations. In particular, the current practices require that SNF criticality analysis for SNF assume that the SNF is fresh nuclear fuel with its high nuclear reactivity (i.e., no burnup credit). Efforts are currently underway to obtain licensing approval for burnup credit, but the amount of credit and the requirements that must be met for approval under transport, storage, or repository conditions are not clear. For the largest MPC, criticality considerations do not currently allow full canister loading of higher enrichment SNF to be shipped. This is an economic penalty.

With the use of DUSCOBS, burnup credit does not appear to be needed. A nuclear criticality analysis (as shown in Table 3) was performed for the largest MPC (assuming DUSCOBS, no burnup credit, and enrichment levels of $3.75 \%$ wt \% and $5 \mathrm{wt} \%$ ). The analysis indicates (Appendix B) that under all circumstances considered, the neutron multiplication factor $\left(k_{e f f}\right)$, the measure of the potential for nuclear criticality combined with established biases and uncertainties, is less than the regulatory limit of 0.95 [U.S. Nuclear Regulatory Commission (NRC)a]. In contrast, Table 3 shows that without the use of DUSCOBS, the large MPC can not be fully loaded with higher enriched PWR nuclear fuel without exceeding the regulatory limits for $k_{\text {eff }}$ For the analysis in Table 3, uranium soda lime glass was used which contains no boron and no major neutron poisons except ${ }^{238} \mathrm{U}$. It is noted that, if the MPC in the transport cask does not prevent water in-leakage in an accident environment, it may be necessary to assume that DUS glass beads escape in the accident or arguments will need to be developed to conclude otherwise.

For high-enriched, low-burnup SNF, glass rods or other neutron absorbers can be placed in fuel assembly control rod and instrument tube channels before loading of the MPC. This mechanism provides criticality control during SNF loading operations and before adding DUS glass beads to the MPC. It is also one mechanism to address accident scenarios where there are concerns about beads flowing from the cask. 
Table 3. Multiplication constant $k_{\text {eff }}$ (measure of criticality safety) ${ }^{\mathrm{a}}$ for the large MPC loaded with fresh PWR nuclear fuel

\begin{tabular}{|c|c|c|}
\hline \multirow[b]{2}{*}{ Filler material } & \multicolumn{2}{|c|}{ Fresh $\mathrm{UO}_{2}$ fuel enrichment levels } \\
\hline & $3.75 w t \%{ }^{235} U$ & 5.00 wt $\%{ }^{235} U$ \\
\hline Air & 0.3782 & 0.4383 \\
\hline Water ${ }^{b}$ & 1.0819 & 1.1428 \\
\hline Glass + aire & 0.3920 & 0.4577 \\
\hline Glass + water ${ }^{b, c}$ & 0.7226 & 0.7797 \\
\hline
\end{tabular}

${ }^{a}$ Regulatory requirement is that $k_{e f f}+$ uncertainty + bias $<0.95$.

${ }^{b}$ Safety analysis of a transport cask requires analysis of the cask with and without water.

${ }^{c}$ Glass beads have $35 \mathrm{vol} \%$ void spaces between beads that can be filled with air or water.

The assumed glass density is $4.1 \mathrm{~g} / \mathrm{cm}^{3}$. The glass is $25 \mathrm{wt} \%$ DU with the uranium assay of $0.2 \%{ }^{235} \mathrm{U}$.

\subsection{RADIATION SHIELDING AND TRANSPORT CASK DESIGN}

The addition of DUS glass beads to an MPC offers the potential of having some of the gamma shielding located within and immediately around the SNF assemblies rather than having it located external of the assemblies. It is a commonly-known fact that if the gamma shielding can be moved inward in a design, the overall weight of the design can be decreased. In addition, if boron is included in the DUS glass beads, the neutron shielding in the walls of both the storage and transport casks might be reduced or even completely eliminated.

Shielding analyses were performed for the MPC concept. These analyses, which are shown in Appendix B, were performed using a three-dimensional (3-D) calculational methodology, and considered full cask loading of SNF with and without DUS glass backfill. Fully loaded conditions used (a) $100 \%$ void in interstitial regions of the assembly and (b) $65 \%$ DUS glass bead and $35 \%$ void for DUS glass bead backfilled conditions. The SNF was assumed to be $3.75 \mathrm{wt} \%$ enriched fuel, with a burnup of $40 \mathrm{GWd} /$ metric tons uranium (MTU), and a 10-year cooling time.

Radiation dose rates were determined at a radial distance of $2 \mathrm{~m}$ from the cask wall, at the axial centerline of the fuel length for two azimuthal angles $0^{\circ}$ and $30.96^{\circ}$. The $0^{\circ}$ rotation angle represents the location which sees the largest source area, while the $30.96^{\circ}$ rotation angle represents the location of closest approach to the source region. 
The details of these calculations, and the breakdown of predicted dose rates for neutrons, primary gamma-rays, and secondary gamma-rays are provided in Tables B.6, B.7, and B.8 of Appendix B, while Table B.9 provides the total dose rates for each condition considered.

It was found from the preliminary calculations that neutron doses could be reduced by $\sim 50 \%$ (see Table B.6), primary gamma-ray doses could be reduced by $\sim 20 \%$ to $25 \%$ (see Table B.7), and secondary gamma-ray doses could be reduced by $\sim 50 \%$ (see Table B.8).

The results of the preliminary shielding calculations are summarized in Table 4.

Table 4. Predicted dose rates for 21-element MPCs in spent fuel shipping casks

\begin{tabular}{lcc}
\hline \multicolumn{1}{c}{ MPC/SNF Shipping Cask Configuration } & $\begin{array}{c}\text { Dose at } 0^{\circ} \\
(\mathrm{mrem} / \mathrm{h})\end{array}$ & $\begin{array}{c}\text { Dose at } 30.96^{\circ} \\
(\mathrm{mrem} / \mathrm{h})\end{array}$ \\
\hline $\begin{array}{l}\text { No Backfill, } \\
\text { Nominal Shield Design }\end{array}$ & 7.3 & 6.3 \\
$\begin{array}{l}\text { DUS Glass Bead Backfill, } \\
\text { Nominal Shield Design }\end{array}$ & 1.9 & 2.0 \\
$\begin{array}{l}\text { DUS Glass Bead Backfill, } \\
\text { No Radial Lead Shield }\end{array}$ & & 3.6 \\
$\begin{array}{l}\text { DUS Glass Bead Backfill, } \\
\text { No Radial Lead Shield and } \\
85 \% \text { of Nominal DU Shield }\end{array}$ & 3.3 & \\
$\begin{array}{l}\text { DUS Glass Bead Backfill, } \\
\text { No Radial Lead Shield and 75\% of Nominal } \\
\text { DU Shield }\end{array}$ & 5.6 & 6.5 \\
\hline
\end{tabular}

Most importantly, however, the results summarized in Table 4 indicate that, if a 21-element SNF MPC were backfilled with DUS glass beads, potentially the design of the cask body can be adjusted to remove:

(a) all of the radial lead shielding, and

(b) approximately $15 \%$ of the radial depleted uranium (DU) gamma shielding.

The results are preliminary at best, and much work is needed to fully understand what could be accomplished by filling the MPC with DUS glass beads. Longitudinal calculations of the dose rates out the ends of the cask are needed. For purposes of estimating changes in weights of designs, it has been assumed that the DUS glass beads added to an MPC would provide sufficient shielding that the need for a DU shield plug in the lid of the MPC could be eliminated. 
Based upon these findings, the weights of the components in the MPC/shipping cask system have been estimated. These are shown in Tables 5 and 6 . Table 5 lists the estimated masses of key components in the large MPC/cask system as presented in the Office of Civilian Radioactive Waste Management conceptual design [U.S. Department of Energy (DOE), 1994b], and Table 6 lists the estimated masses of key components in design adjusted to remove:

(a) all of the radial lead shielding,

(b) approximately $15 \%$ of the radial DU gamma shielding, and

(c) the DU shield plug in the lid of the MPC.

The variation in materials as a function of cask length has been accounted for in these calculations. These calculations show that even with the removal of the lead gamma shielding, part of the DU gamma shielding, and the DU shield plug, the MPC/cask system with DUS glass beads added could have a mass greater than the MPC/cask system without DUS glass beads. However, the growth in mass is not that great $(\sim 4.3 \mathrm{t}), \sim 4.6 \%$ growth based upon the initial conceptual designs for this system. Further, it is recalled that the conceptual design of the 125 -ton system in reality only weighed about 105 tons. Should the DUS glass bead backfill concept be pursued, one of the issues that will need to be addressed as the tradeoff studies are performed is to monitor the growth in the mass of the system, and ensure that it is kept within acceptable bounds.

It may also be possible to reduce total system weight by design optimization. Some examples of methods to improve shielding performance while reducing the weight include the following:

- Glass compositions can be modified to reduce the neutron dose from the MPC.

- Monolithic glass blocks with $\sim 50 \%$ greater density can be used to fill the void spaces between the square SNF baskets and the round MPC wall. The glass beads typically are $65 \mathrm{vol} \%$ glass and 35 vol \% void space. Monolithic glass eliminates the void space. Simultaneously, lower density glass beads can be used in the interior of the MPC. The net result of using monolithic glass would be to displace the glass toward the outer sections of the MPC with better shielding performance per unit weight of glass and consequent lower system weight.

\subsection{THERMAL ANALYSIS}

A major design constraint for the MPC is the maximum allowable SNF cladding temperature. A preliminary analysis was completed (Appendix C). Based on this analysis, the MPC with DUSCOBS meets the design limits. The analysis also indicated that DUSCOBS does not have a major impact on the peak SNF temperature in the MPC. This result is a consequence of several factors (Fig. 3): 
Table 5. Estimated mass of key components of current large MPC/cask system*.

\begin{tabular}{|c|c|c|c|c|c|c|}
\hline Component & Material & $\begin{array}{c}\text { Inner Radius } \\
\text { (in) }\end{array}$ & $\begin{array}{l}\text { Outer Radius } \\
\text { (in) }\end{array}$ & $\begin{array}{c}\text { Length } \\
\text { (in) }\end{array}$ & $\begin{array}{c}\text { Density } \\
(\mathrm{g} / \mathrm{cc})\end{array}$ & $\begin{array}{c}\text { Mass } \\
(\mathrm{kg})\end{array}$ \\
\hline Inner Shell & SS & 30.5 & 32.0 & 202.25 & 7.75 & 7,568 \\
\hline $\begin{array}{l}\text { Inner } \\
\text { Gamma } \\
\text { Shield }\end{array}$ & $\begin{array}{c}\text { SS/ } \\
\text { DU/ } \\
\text { SS }\end{array}$ & 32.0 & 33.5 & $\begin{array}{c}18 / \\
166 / \\
18.25\end{array}$ & $\begin{array}{c}7.75 / \\
19.05 / \\
7.75\end{array}$ & 17,423 \\
\hline $\begin{array}{l}\text { Outer } \\
\text { Gamma } \\
\text { Shield }\end{array}$ & $\begin{array}{l}\mathrm{SS} / \\
\mathrm{Pb} / \\
\mathrm{SS}\end{array}$ & 33.5 & 34.0 & $\begin{array}{c}12 / \\
180 / \\
10.25\end{array}$ & $\begin{array}{c}7.75 / \\
11.34 / \\
7.75\end{array}$ & 3,848 \\
\hline $\begin{array}{l}\text { Outer } \\
\text { Shell }\end{array}$ & SS & 34.0 & 36.5 & 208.25 & 7.75 & 14,650 \\
\hline N-Shield & N-Shield & 36.5 & 42.5 & 180 & 0.91 & 3,999 \\
\hline $\begin{array}{l}\text { N-Shield } \\
\text { Cover }\end{array}$ & SS & 42.5 & 42.25 & 180 & 7.92 & 1,564 \\
\hline Cask Lid & SS & 0.0 & 34.25 & 6 & 7.75 & 2,809 \\
\hline \multicolumn{6}{|c|}{ Subtotal for Cask } & 51,951 \\
\hline $\begin{array}{l}\text { MPC } \\
\text { Shield } \\
\text { Plug. }\end{array}$ & & & & & & 1,989 \\
\hline \multicolumn{6}{|c|}{ Total for Cask and MPC Shield Plug } & 53,940 \\
\hline
\end{tabular}

*Does not include all MPC/Cask Components; only includes that would be affected by change. 
Table 6. Estimated mass of key components of large MPC/cask system modified to accommodate DUS glass beads*.

\begin{tabular}{|c|c|c|c|c|c|c|}
\hline Component & Material & $\begin{array}{c}\text { Inner Radius } \\
\text { (in) }\end{array}$ & $\begin{array}{l}\text { Outer Radius } \\
\text { (in) }\end{array}$ & $\begin{array}{l}\text { Length } \\
\text { (in) }\end{array}$ & $\begin{array}{l}\text { Density } \\
(\mathrm{g} / \mathrm{cc})\end{array}$ & $\begin{array}{c}\text { Mass } \\
(\mathrm{kg})\end{array}$ \\
\hline Inner Shell & SS & 30.5 & 32.0 & 202.25 & 7.75 & 7,568 \\
\hline $\begin{array}{l}\text { Inner } \\
\text { Gamma } \\
\text { Shield }\end{array}$ & $\begin{array}{l}\text { SS/ } \\
\text { DU/ } \\
\text { SS }\end{array}$ & 32.0 & 33.275 & $\begin{array}{l}18 / \\
166 / \\
18.25\end{array}$ & $\begin{array}{c}7.75 \prime \\
19.05 \prime \\
7.75\end{array}$ & 14,758 \\
\hline $\begin{array}{l}\text { Outer } \\
\text { Gamma } \\
\text { Shield }\end{array}$ & $\begin{array}{l}\mathrm{SS} / \\
\mathrm{Pb} / \\
\mathrm{SS}\end{array}$ & None & None & N/A & N/A & 0 \\
\hline $\begin{array}{l}\text { Outer } \\
\text { Shell }\end{array}$ & SS & 33.275 & 35.775 & 208.25 & 7.75 & 14,348 \\
\hline N-Shield & N-Shield & 35.775 & 41.775 & 180 & 0.91 & 3,925 \\
\hline $\begin{array}{l}\text { N-Shield } \\
\text { Cover }\end{array}$ & SS & 41.775 & 42.025 & 180 & 7.92 & 1,538 \\
\hline Cask Lid & SS & 0.0 & 34.25 & 6 & 7.75 & 2,809 \\
\hline & & Subtotal f & Cask. & & & $.44,946$ \\
\hline $\begin{array}{l}\text { MPC } \\
\text { Shield } \\
\text { Plug }\end{array}$ & $\mathrm{DU}$ & None & None & N/A & N/A & 0 \\
\hline Shorten MPC 3 & ches & & & & & -106 \\
\hline Shorten Cask 3 & ches & & & & & -418 \\
\hline DU Glass Bead & & & & & & 13,858 \\
\hline \multicolumn{6}{|c|}{ Total for Cask and MPC Shield Plug } & 58,280 \\
\hline
\end{tabular}

*Does not include all MPC/Cask Components; only includes that would be affected by change. 
FUEL ASSEMBLY

FUEL PIN

FUEL ASSEMBLY HEAT TRANSPORT

- HIGH THERMAL CONDUCTIVITY METAL CLAD

- HEAT CONDUCTS ACROSS NARROW GAPS BETWEEN FUEL PINS

- BASKET WALL

BASKET HEAT TRANSPORT

- HIGH THERMAL CONDUCTIVITY BASKET

- HEAT CONDUCTION VIA BASKET

000

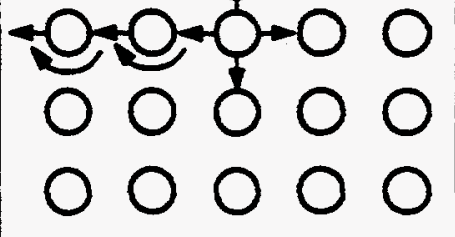

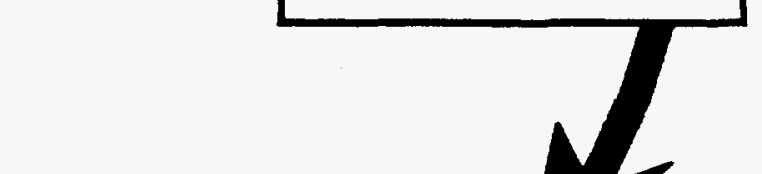
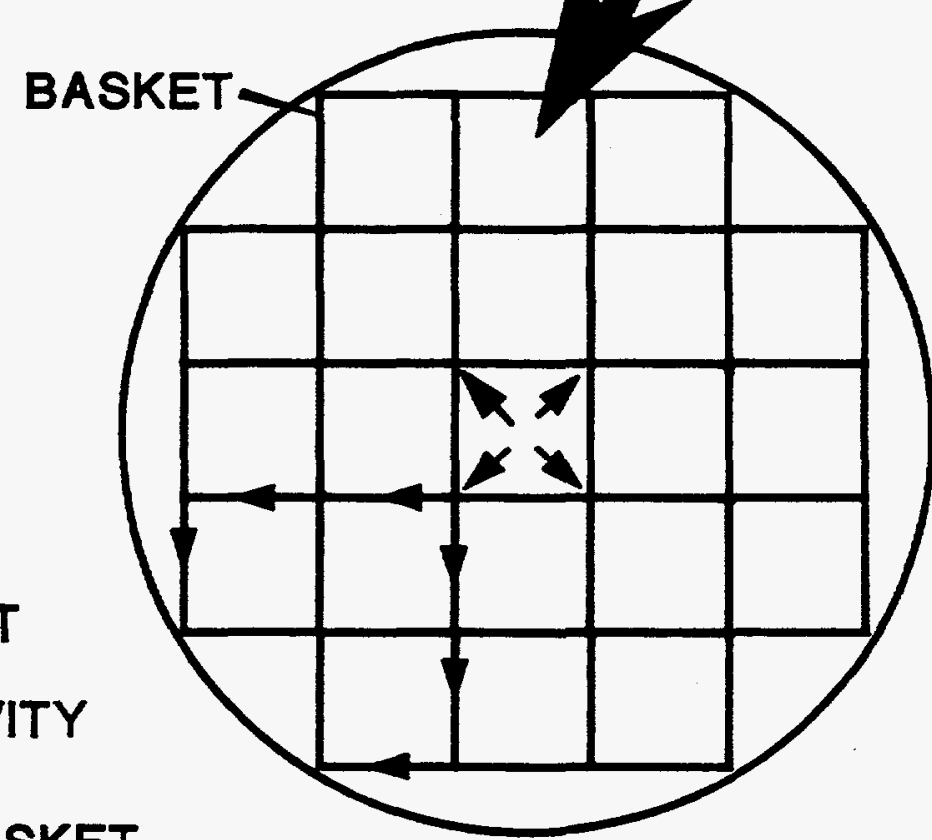

Fig. 3. Major heat transfer paths in the MPC and other SNF packages. 
- The heat generated by the SNF must be transported from the SNF to the outside metal wall of the MPC. Although the fill material (air, water, or glass beads) transfers heat from the fuel pins to the inner MPC structure, it is not a dominant mechanism for heat transfer to the outer MPC wall because of the higher thermal conductivity of the materials of which the basket is fabricated (boral and aluminum).

- Within a fuel assembly, much of the heat is transferred by the fuel-pin metal cladding because of its high thermal conductivity. Heat transfer is from the cladding of one pin to the cladding of the next pin, across the narrow gaps between pins to the basket walls. Within a range of thermal conductivities, the impact of the fill material on the fuel pin temperature is low. The temperature drop across the fuel pin gaps is small compared to all of the other temperature drops across different materials from the $\mathrm{UO}_{2}$ to the exterior of the cask.

- Heat is transported between pins within the fuel assembly by thermal convective air currents, thermal radiation, and thermal conduction. Adding glass beads reduces the heat transfer by the first two phenomena, but since the thermal conductivity of the glass is higher than the air, the net effect is predicted to result in about the same fuel pin temperature.

Based on the preliminary analysis, DUSCOBS reduces heat-transfer uncertainties. Heat transfer within the current design of MPC is partly by conduction, partly by radiation, and partly by gas convection. Radiation heat-transfer is strongly dependent upon SNF surface conditions. Gas convection heat transfer depends upon MPC orientation. In contrast, conduction heat transfer with glass beads is not impacted significantly by random factors such as SNF surface conditions or cask orientation.

\subsection{STRUCTURAL INTEGRITY}

The MPC is loaded within a transport cask overpack to move SNF. The MPC and outer cask must withstand severe transport accidents. The MPC must ensure that the SNF geometries are maintained under accident conditions and are not altered by rapid acceleration or deceleration. DUSCOBS acts as a packing material for the SNF that should help dampen vibrations during normal operations and maintain geometries under accident conditions. 


\section{REPOSITORY BENEFITS AND CONSIDERATIONS}

The goal of a repository is to prevent the release of radionuclides from the SNF to the open environment. Because radionuclides decay over time to nonradioactive isotopes, radionuclide release is prevented only if the radionuclides in SNF are isolated for a sufficient time for decay to nonradioactive materials. DUSCOBS may improve isolation in several ways.

\subsection{REDUCED RADIONUCLIDE RELEASE RATE FROM WASTE PACKAGE}

The dominant expected repository failure mode is radionuclide migration to the open environment by (1) water leaching SNF, (2) dissolution of radionuclides and generation of colloids, and (3) transport of those radionuclides in dissolved or colloid forms to the open environment. DUSCOBS offers the potential to reduce radionuclide releases by two mechanisms: (1) reduced water flow through the MPC inside the disposal overpack, and (2) reduced radionuclide release rates from the package.

\subsubsection{Mechanisms of Degradation of SNF in a Geological Repository}

LWR SNF consists of bundled sets of Zircaloy tubes each of which contains $\mathrm{UO}_{2}$ fuel pellets (Appendix A). The fission products and actinides are primarily located within the $\mathrm{UO}_{2}$ fuel pellets. The release of fission products and actinides from the SNF is limited by the rate of alteration and dissolution of the $\mathrm{UO}_{2}$ fuel matrix (Finn, Hoh, Bates, and Wolf, December 1994). Most of the radionuclides escape as the $\mathrm{UO}_{2}$ matrix is destroyed.

Over geological time, the waste package and the SNF cladding will fail, and the $\mathrm{UO}_{2}$ will be exposed to the repository environment. The initial chemical reactions with water in many cases form a protective layer that slows alteration of the $\mathrm{UO}_{2}$ (Nicol and Needes 1975; Nicol and Needs 1977; Shoesmith, Sunder, Bailey, and Wallace 1988). The detailed mechanisms of SNF degradation and radionuclide release are dependent upon the local groundwater chemistry-particularly the oxidation potential of the groundwater (Johnson and Shoesmith 1988).

\subsubsection{Oxidizing Groundwater Impacts on SNF}

In an oxidizing groundwater environment such as at the proposed Yucca Mountain repository site, the $\mathrm{UO}_{2}$ over time will be oxidized from the +4 valence state in $\mathrm{UO}_{2}$ to the +6 valence state. Uranium in the +6 valence state is generally more soluble in groundwater than is uranium in the +4 valence state. The actual solubility of the uranium in the +6 valence state is highly dependent upon other chemical species in the 
groundwater. If silicates are dissolved in the groundwater, the uranium will usually undergo a series of chemical transformations to more stable, less soluble uranyl silicates (Bruton and Shaw 1988; Finn, Hoh, Bates, and Wolf, December 1994). Silicates often control the solubility of uranium. It is found that silicates can lower the solubility of uranium in water by more than two orders of magnitude-presumably due to the lower solubility of uranium silicates compared to other uranium compounds.

The transformation process of $\mathrm{UO}_{2}$ to other uranium compounds that can allow the escape of water soluble fission products and the formation of americium and curium colloids that can be transported by groundwater to the environment has been studied extensively. The transformation processes observed in laboratory tests of SNF are similar to those transformations seen in uranium ore bodies over geological time (Wronkiewicz, et al. 1992). The transformation processes are initially rapid but slow with time and the formation of protective uranyl silicate surfaces on the $\mathrm{UO}_{2}$.

\subsubsection{Reducing Groundwater Impacts on SNF}

With chemically reducing groundwater, $\mathrm{UO}_{2}$ does not change its chemical form. The dissolution rate of $\mathrm{UO}_{2}$ is determined by total water flow and the difference between the uranium dissolved in the groundwater and the solubility of uranium in groundwater. The solubility of uranium in reducing groundwater is low.

\subsubsection{DUSCOBS Chemical Effects on Repository Performance}

Backfilling the waste package with a DUS silicate glass creates a groundwater environment within the waste package saturated in uranium species and silicates. The small glass beads with their high surface areas ensure that the groundwater is saturated with this DU without fission products rather than uranium with fission products from the SNF. This uranium silicate saturated environment slows the transformation and dissolution of the $\mathrm{UO}_{2}$ in the fuel elements via several mechanisms.

The DUS glass saturates the local groundwater with uranium. The rate of uranium dissolution and transport (when kinetics does not further reduce dissolution rates) is proportional to the difference between the uranium concentration in the water at the $\mathrm{SNF} \mathrm{UO}_{2}$ surface and the solubility of uranium in that groundwater. Uranium saturated groundwater does not dissolve uranium fuel pellets.

Silicates further reduces SNF transformation and dissolution by multiple mechanisms:

- Uranium silicate is much less soluble in most groundwaters than most other uranium compounds (Sadeghi, et al., 1990). This reduces the quantity of uranium that can dissolve in a unit of groundwater. It implies much longer times until the uranium in the waste package is dissolved and transported. This implies better radionuclide isolation. 
- The uranium silicate saturated solution also helps form insoluble layers of uranium silicates over the $\mathrm{UO}_{2}$ crystals in the SNF. This kinetically slows uranium alteration and dissolution. This mechanism would be expected to be particularly important in oxidizing groundwater environments. In such environments other soluble radionuclides may be released and colloids may be formed during chemical transformations. The transformations may not result in much uranium transport but can create the potential for release of other radionuclides.

These mechanisms are not unique to DUSCOBS. They are the mechanisms that prevent large uranium ore deposits from rapidly dissolving in groundwater and being transported to the oceans. The uranium in the outer parts of the ore deposit protects the uranium in the inner sections of the deposit. DUSCOBS is using the same uranium silicate geochemistry that is observed in nature to preserve uranium ore bodies. The detailed chemistry is complex.

\subsubsection{DUSCOBS Physical Effects on Repository Performance}

The backfill serves several other functions. It lowers the hydraulic conductivity within the package and thus ensures low water flow rates inside the waste package. Water flow is the primary mechanism for the transport of radionuclides to the open environment. The release of many radionuclides is controlled by solubility limits (Sadeghi, et al. 1990). The slower the flow of groundwater, the slower the transport of radionuclides.

The backfill may also reduce colloid transport. Experimental evidence indicates that much of the americium and curium are transported as colloids rather than as dissolved in the water (Finn, Gong, Bates, Emery, and Hoh 1994). Particle sizes typically exceed $1 \mathrm{~nm}$. The beads may act together as a "filter" for these colloids. For optimum filter capabilities, appropriate glass-bead sizes and distributions of sizes are required.

Last, the backfill helps maintain the form of package for long periods of time. The total radionuclide releases from a package by groundwater flow depends upon groundwater flow in and around the waste package. The cylindrical shape of a waste package has a relatively small surface-to-volume ratio which in turn minimizes the interactions of water with the package. If the package is not backfilled, it will ultimately collapse and further disturb the local geology and produce more flow of water by the radioactive materials.

\subsection{AVOIDANCE OF NUCLEAR CRITICALITY}

Nuclear criticality should be avoided in a geological repository to prevent the release of radionuclides to the environment. Naturally occurring nuclear reactors in the geological past [Cowan 1976, International Atomic Energy Agency (IAEA) 1975, IAEA 1977, and Smellie 1995] indicate that such events generate both 
added radioactivity and heat over time periods of hundreds of thousands of years. The heat generated creates higher repository temperatures that (1) drive chemical reactions, which in turn, degrade SNF packages and SNF, (2) cause water movement within a repository that may transport radioactivity to the environment (Buscheck and Nitao 1993), and (3) create major uncertainties in repository performance. Water movement can be accelerated in both unsaturated (Buscheck, Nitao, and Wilder 1993) and saturated geological environments by heat. In this context, it is important to emphasize that the concern is not that nuclear criticality occurs or that some radioactivity is added to the repository, but rather that it occurs sufficiently often for a time sufficient to generate significant amounts of heat. Heat is a driver for radionuclide transport.

After SNF is disposed of, there is significant radioactive decay heat. To minimize the potential impacts of heat on repository performance, the SNF is packaged in long-lived waste packages. The radioactive decay heat decreases to low levels before the waste packages degrade significantly. The package provides waste isolation during the periods of high heat release. Nuclear criticality, should it occur, would occur after loss of waste package integrity.

There are two types of repository criticality concerns (Fig. 4): nuclear criticality involving a single waste package with a single MPC and nuclear criticality involving fissile material from multiple MPCs.

\subsubsection{Package Criticality}

Over time, the waste package and the MPC will degrade. Water will selectively leach components from the MPC. In particular, it is known (Vernaz and Godon 1992) that boron and certain other neutron poisons will leach preferentially from a waste package (Fig. 4). If the MPC contains sufficient fissile material, it may become critical. Such criticality is primarily a problem associated with large MPCs loaded with PWR SNF which have the highest total fissile content within a single MPC.

DUSCOBS prevents this type of criticality because DU is a neutron poison. The uranium in the SNF and the DU in DUSCOBS transform to the same chemical compounds with the same chemical characteristics; hence, they do not separate from each other (Sect. 5.1). The use of DUSCOBS to prevent repository package nuclear criticality was investigated for the MPC (Appendix B) using a very conservative set of assumptions:

- Fresh PWR nuclear fuel with no burnup credit.

- Neutron poison (boron) in the MPC grid structure to be fully leached from the package.

- DUSCOBS glass to be uranium loaded soda lime glass in which the only major neutron absorber is DU. The alternative Loffler glass has a very high neutron absorption capability due to its boron and rare earth content. 
INITIAL CONDITIONS $\left(T=T_{0}\right)$

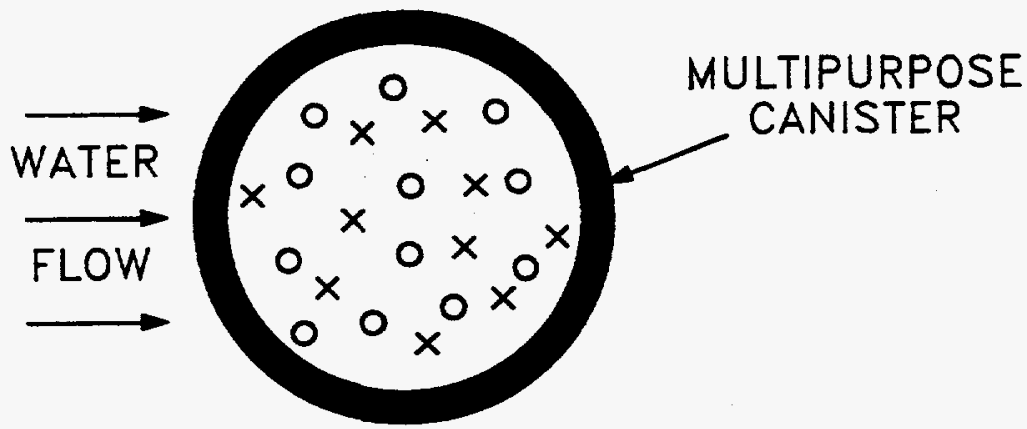

$\times$ NEUTRON POISON

- FISSILE MATERIAL

PACKAGE CRITICALITY $\left(T=T_{0}+T_{1}\right)$

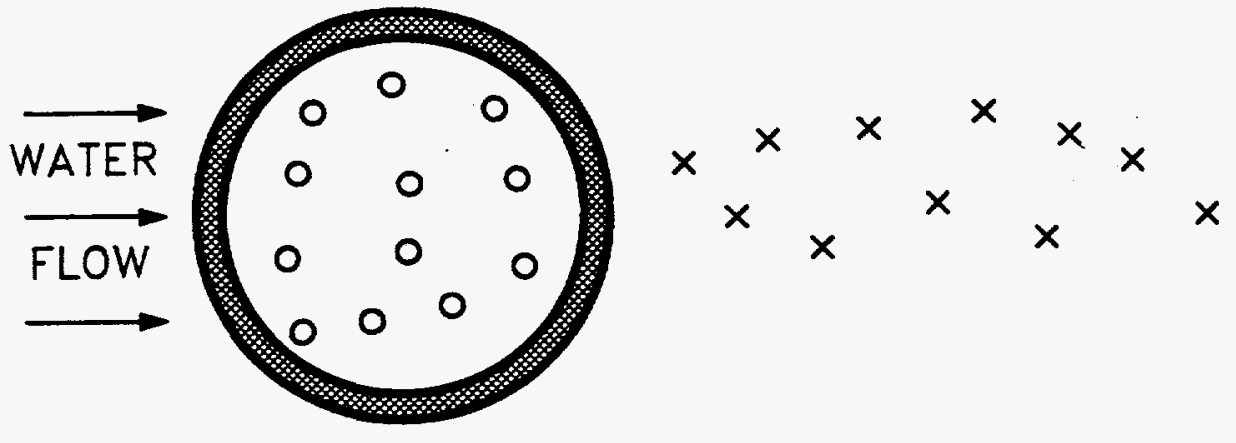

\section{ZONE CRITICALITY $\left(T=T_{0}+T_{1}+T_{2}\right)$}
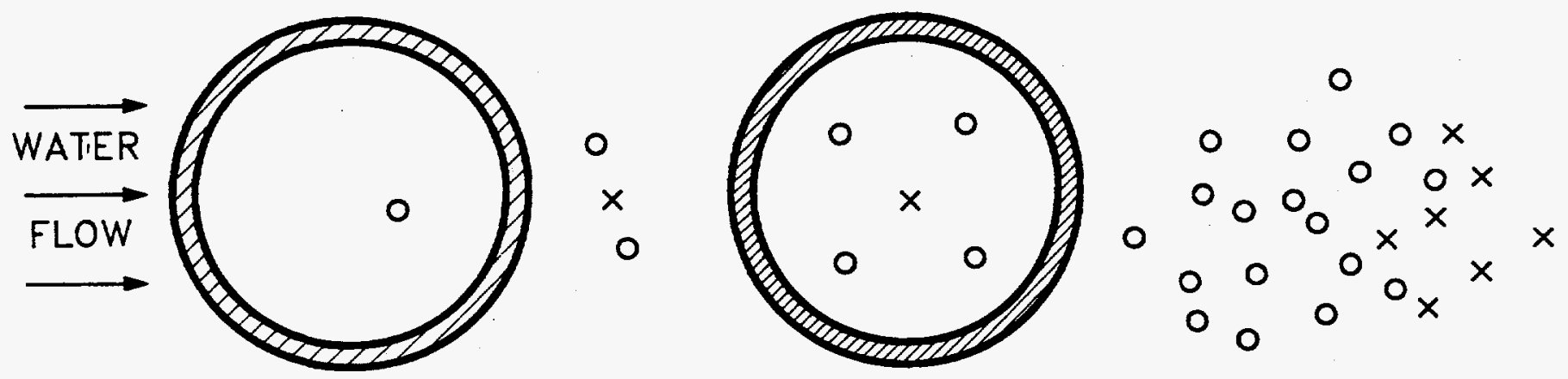

Fig. 4. Alternative repository criticality scenarios. 
The addition of DU eliminates package criticality concerns. The calculated neutron multiplication constant $\left(k_{\text {eff }}\right)$ is $<1$ (nuclear criticality occurs at $k_{\text {eff }}=1$ ) and below the regulatory requirements of $k_{\text {eff }}$ $<0.95$. Table 7 shows the neutron multiplier $\left(k_{\text {eff }}\right)$ for several examples. These could be considered worst case examples in that it is assumed all of the boron is selectively leached from the waste package system. The examples are:

- MPC with air backfill.

- MPC flooded with water.

- MPC with DUSCOBS and air in the void spaces.

- MPC with DUSCOBS and water in the void spaces.

Table 7. Neutron multiplication factor $\left(k_{e f f}\right)$ for fully loaded MPCs in which all boron has been removed from the waste package ${ }^{a}$

\begin{tabular}{|c|c|c|}
\hline \multirow[t]{2}{*}{ Filler material } & \multicolumn{2}{|c|}{ Fresh fuel enrichment levels } \\
\hline & $3.75 \%$ & $5.0 \%$ \\
\hline Air & 0.4059 & 0.4690 \\
\hline DUSCOBS with air ${ }^{b}$ & 0.4337 & 0.5057 \\
\hline Water & 1.1988 & 1.2643 \\
\hline DUSCOBS with water ${ }^{b}$ & 0.8756 & 0.9347 \\
\hline
\end{tabular}

${ }^{a}$ Regulatory requirement is $k_{\text {eff }}+$ uncertainty + bias $<0.95$.

${ }^{b}$ Assumes backfill material is $65 \mathrm{vol} \%$ glass and $35 \mathrm{vol} \%$ void space. The assumed glass density is $4.1 \mathrm{~g} / \mathrm{cm}^{3}$ with $25 \mathrm{wt} \%$ DU with $0.2 \%{ }^{235} \mathrm{U}$.

\subsubsection{Zone Criticality}

\subsubsection{Mechanisms of Zone Criticality}

In a geological environment, chemical neutron poisons (boron, rare earths, cadmium, etc.) will separate from the uranium, and the uranium will dissolve in groundwater, migrate and then redeposit. Uranium dissolves in oxidizing groundwater and then precipitates under chemically reducing conditions (Wronkiewicz et. al. 1992 and Smellie 1995). Uranium may also be precipitated by the formation of less 
soluble uranium species in the same uranium oxidation state. These are the mechanisms that created natural uranium ore bodies. In a repository, the same geological mechanisms will operate and may concentrate and purify uranium (Fig. 5). Some of these mechanisms may be accelerated within repositories with oxidizing conditions by the inclusion of chemical reducing agents in the repository (i.e. iron in waste packages) and tunnel support systems (i.e. rock bolts, etc.) that create local chemical reducing conditions. This is a much longer term phenomena (Fig. 4) than package criticality and occurs latter in time ( $\left.T=T_{0}+T_{1}+T_{2}\right)$.

If the uranium enrichment is sufficiently high and the quantities of uranium are sufficient, nuclear criticality will occur. The historical geological record (Brookins 1990, Cowan 1976, and Smellie 1995) shows that nuclear criticality has occurred in natural uranium ore bodies because of these mechanisms in the past. At the Oklo, Africa site, 15 fossil, natural, nuclear reactors have been identified which operated when the ${ }^{235} \mathrm{U}$ enrichment of natural uranium was $3.6 \%$. After operation with the generation of heat and fission products, ${ }^{235} \mathrm{U}$ enrichments of the uranium were as low as $1.3 \%$-equivalent to the fissile enrichment of fullburnup LWR SNF.

The French atomic energy commission has studied the conditions under which natural nuclear reactors form (Naudet, 1977). Their analysis indicates that nuclear criticality may occur at enrichments as low as $1.28 \%$; but, becomes reasonably probable in some geological environments as enrichments approach $1.64 \%$. Note that the quantities of fissile uranium in any geological repository far exceed the quantities of fissile uranium in any natural ore body or mining district.

Criticality calculations [American National Standards Institute (ANSI) 1983] and laboratory experiments (Paxton and Pruvost 1987) with the types of materials found in the natural environment indicate that nuclear criticality could in theory occur with fissile enrichment concentrations as low as $1 \%{ }^{235} \mathrm{U}$, but there is no experimental evidence of this having occurred in nature. This would require nearly incredible conditions. Figure 6 shows the volume of material needed to create a critical mass versus the enrichment of the uranium. The quantities of uranium in the appropriate geometry increase rapidly as the uranium enrichment levels decrease to $1 \%$. For homogeneous systems, nuclear criticality is impossible with enrichment levels near $1 \%$. With heterogeneous mixtures of uranium and water, nuclear criticality can occur with enrichment levels somewhat lower than $1 \%$ but this requires very special geometries with the uranium in lumped geometries of appropriate sizes, spacing between uranium lumps, and other neutron moderators (carbon, etc.).

Modeling studies for disposal of high-enriched SNF in repositories using waste packages not filled with DUS glass beads show nuclear criticality to be the major technical issue for disposition of such fuels (Rechard 1993 and Patric 1992). The models conclude that criticality may occur as has occurred in the natural environment. The uncertainties associated with geochemical evolution of a repository with time make predictions of the future highly uncertain. 

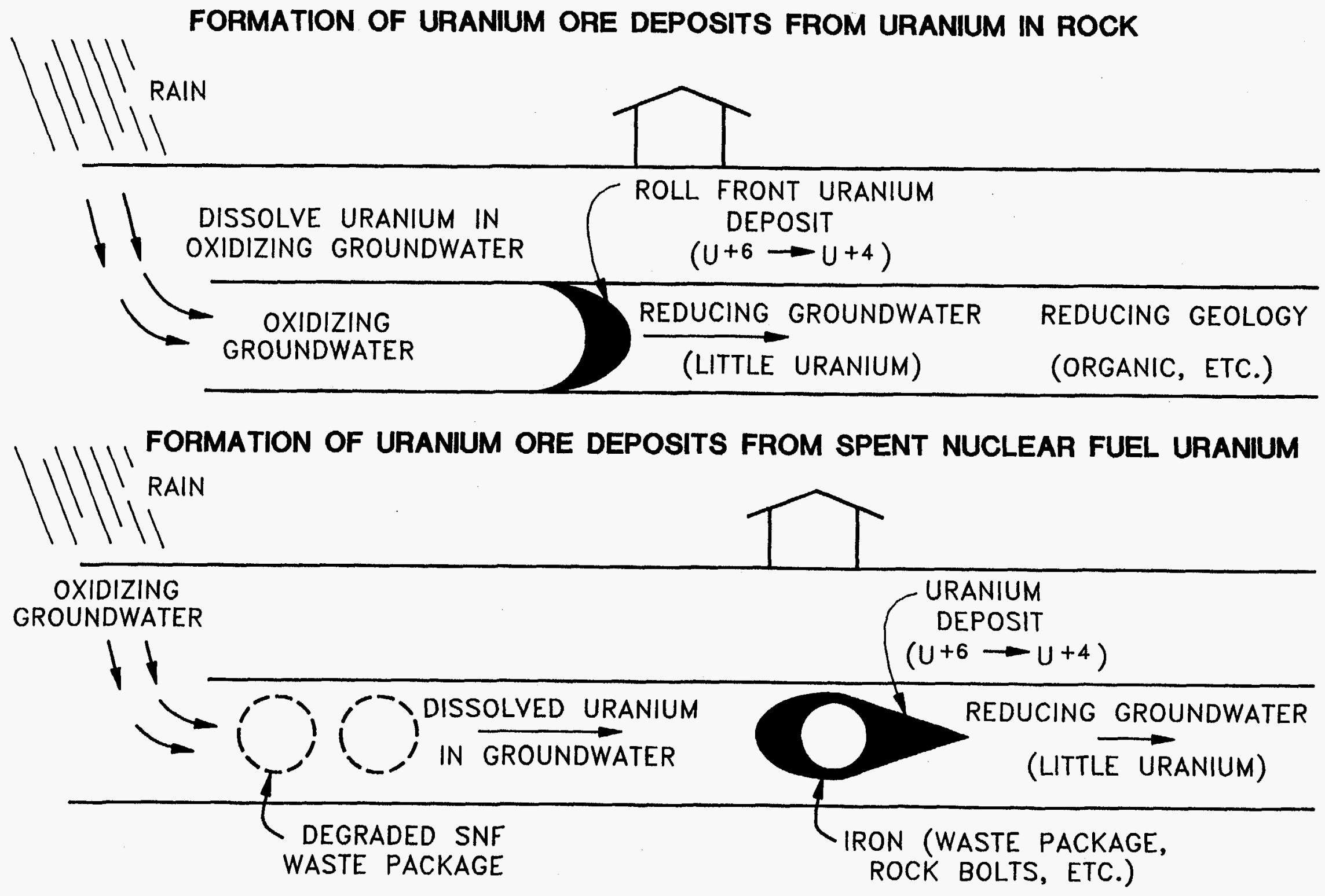

Fig. 5. Natural and man-made formation of uranium ore deposits. 
ORNL DWG 95A-582

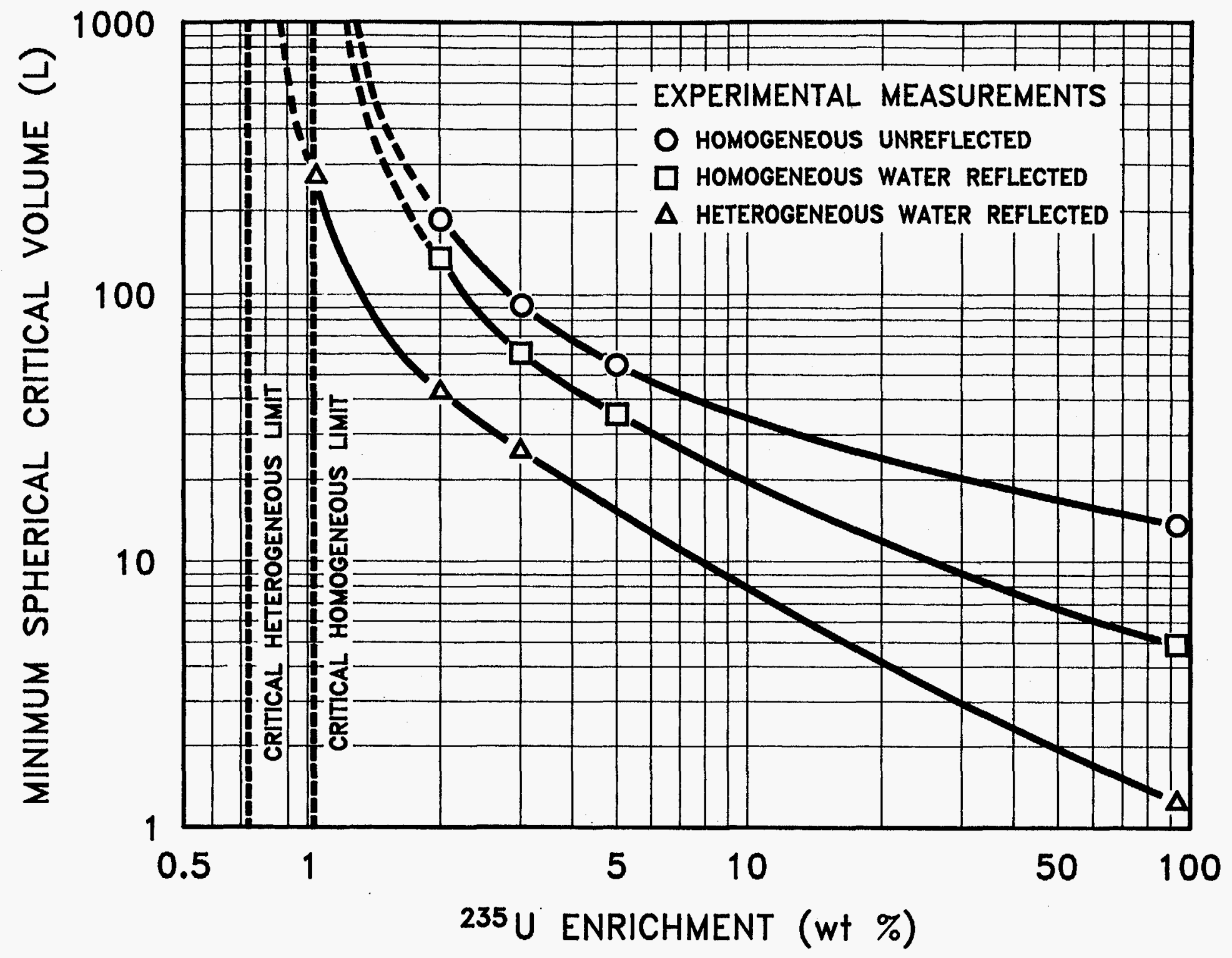

Fig. 6. Minimum spherical critical volumes as functions of ${ }^{235} \mathrm{U}$ enrichment in homogeneous and heterogeneous hydrogen-moderated systems. 


\subsubsection{Fissile Content of SNF}

An analysis was made of the fissile content of the total LWR SNF inventory in the United States (Appendix B). LWR SNF contains several fissile materials- ${ }^{235} \mathrm{U},{ }^{239} \mathrm{Pu}$ and other isotopes. In time, fissile materials such as ${ }^{239} \mathrm{Pu}$ decays to ${ }^{235} \mathrm{U}$ and ${ }^{241} \mathrm{Pu}$ decays to ${ }^{233} \mathrm{U}$; thus, fissile plutonium in the SNF ultimately is converted to ${ }^{233} \mathrm{U}$ or ${ }^{235} \mathrm{U}$. Long-term avoidance of nuclear criticality is avoidance of criticality from uranium enriched in ${ }^{233} \mathrm{U}$ and ${ }^{235} \mathrm{U}$. For this analysis, the fissile content was defined as the sum of the ${ }^{235} \mathrm{U},{ }^{239} \mathrm{Pu}$ and ${ }^{241} \mathrm{Pu}$ divided by the total uranium and plutonium content of the SNF. The results of the analysis are shown in Fig. 7. The average fissile content is $1.47 \%$. The average fissile content of the geological repository is expected to increase with time because of five factors:

- High burnup SNF. High-burnup LWR SNFs are being developed. These fuels reduce (a) natural uranium requirements per unit energy produced and (b) the quantities of SNF to the repository, but the average fissile content of the SNF is higher. For example, increasing SNF burnup (Ludwig and Renier 1989) from 33,000 megawatt-days (MWd)/t to 50,000 MWd/t increases the fissile content of the SNF by $0.1 \%$. This directly follows from the higher fission product and burnable neutron poison levels in the SNF that in turn necessitate a higher fissile content in the discharge SNF.

- Power reactor shutdown. Typically, when a power reactor is refueled, it replaces a fourth to a third of the reactor core. When the reactor is decommissioned, the full reactor core is discharged. Two thirds to three-fourths of the SNF will not be fully burned and will consequently have higher enrichments. The quantities of excess fissile material in this SNF depend upon how far in advance the shutdown is known. The ordering of nuclear fuel is typically 6 to 8 years before the SNF is discharged. If a decision to shutdown a reactor is made fewer than 8 years in advance, there will be significant excess fissile material in the SNF. Only a few reactors to date have been shut down, and these have been shutdown only after a few years or less notice.

- Low-cost nuclear fuel. Nuclear fuel is chéap, but nuclear power plants are expensive. Therefore, strong incentives exist to improve plant availability in a highly competitive environment. This implies that if a power plant is shut down to repair some failed equipment, it may be refueled at the same time to avoid a later refuelling outage. This is economically efficient, but it increases the fissile content of SNF.

- Disposition of plutonium. With the end of the cold war have come plans to dispose of excess plutonium from nuclear weapons. This material may go into a geological repository (1) after it is mixed with HLW and converted to glass or (2) after it is fabricated into mixed-oxide nuclear fuel and then used as power reactor fuel. Its fissile enrichment levels, particularly with plutonium in HLW glass, will be significantly higher than that of LWR SNF.

- Disposition of navy and research reactor SNF. There are significant quantities of these highenriched SNFs which if sent to the repository will raise the average fissile enrichment of the repository. 
ORNL DWO 85A-561R

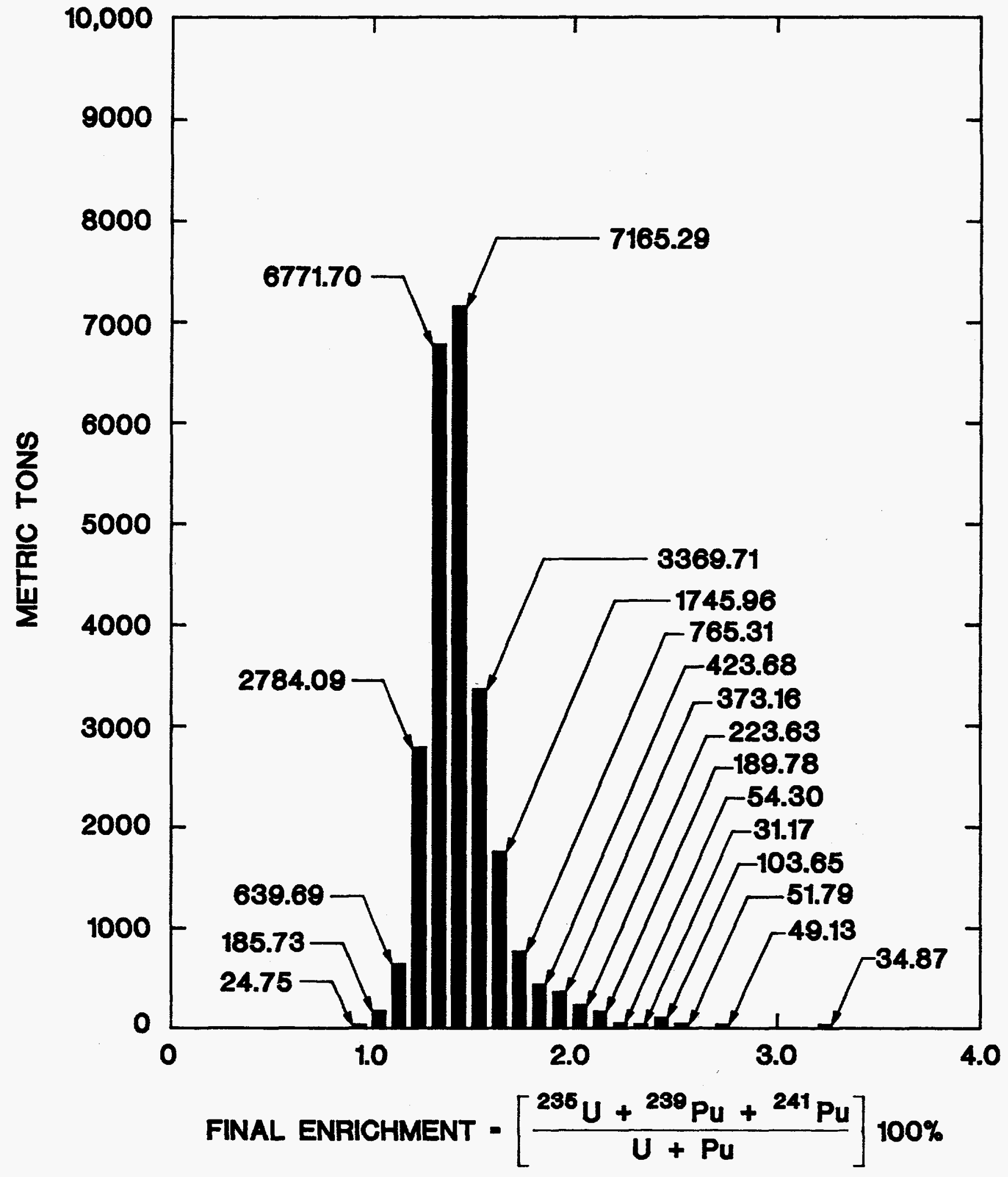

Fig. 7. LWR SNF fissile enrichment levels. 
The combination of these factors suggests that the average enrichment of the nuclear materials in the repository will likely exceed $1.6 \%$ and may be significantly higher.

\subsubsection{Occurrence of Nuclear Criticality Based on Geological History}

The fissile concentration of LWR SNF (1.47\%) exceeds the minimum fissile concentration that was necessary to obtain nuclear criticality in the Oklo mining district in Gabon, Africa. The fissile concentrations of SNF are expected to increase with time. The enrichment of some SNF is much higher; this implies part of the repository will have higher enrichments than the average enrichment. The total quantities of fissile material in projected repositories far exceeds the fissile content of any set of natural uranium ore bodies or uranium mining districts. The history of uranium ore deposits indicates a significant probability that nuclear criticality will occur in time in a geological repository for SNF. Geological history does not provide any information about when such events may happen and provides only limited information about the consequences.

Nuclear criticality concerns may be eliminated by backfilling the MPC with DUS glass. Uranium in the fuel assemblies will isotopically exchange (Benedict 1957) with uranium in the backfill, over geological time, as the uranium that has dissolved in water migrates within the waste package. Uranium ions in solution continuously exchange places with uranium ions in the various solids. There is no large energy barrier to isotopic exchange, and the large isotopic entropy of mixing effect encourages this reaction (Moore 1962). This mechanism allows isotopic dilution of the SNF uranium to levels below $1.3 \%$ creating a low enriched uranium $\left(<1 \%{ }^{235} \mathrm{U}\right)$ geological environment where nuclear criticality can not occur. The geological experience shows no examples of criticality with equivalent uranium enrichments below $1.3 \%$

Table 8 shows the average MPC enrichments for different backfill materials with different uranium densities-assuming that the DU has an enrichment of $0.2 \%$ and that the MPC is filled with PWR SNF. The same information in graphical format is shown in Fig. 8. For uranium densities of the backfill material of 1 to $2 \mathrm{~g}$ of uranium per cubic centimeters, average package enrichments will be near $1 \%$. It is noted that these package enrichments are for the MPC which was designed for minimum free volume; other designs with, greater free volume would result in even lower average package enrichments. The option exists to expand the size of the MPC or use an overpack with added DUS glass to lower package enrichments to much lower levels.

In recent years, speculation has arisen that other types of criticality events might occur in geological repositories (Bowman and Venneri 1994) in addition to those demonstrated to have occurred at Oklo. However, these postulated criticality events appear to require very special conditions that are unlikely or perhaps impossible. It is noted that use of DU backfill would also eliminate these theoretical criticality concerns because of the isotopic dilution of ${ }^{235} \mathrm{U}$ with large quantities of ${ }^{238} \mathrm{U}$. 
Table 8. Average MPC enrichments (wt \%) for different PWR SNF enrichment levels and different uranium density backfill materials with $0.2 \%{ }^{235} U^{a}$

\begin{tabular}{cccccc}
\hline $\begin{array}{c}\text { Uranium density in backfil } \\
\left(\mathrm{g} / \mathrm{cm}^{3}\right)\end{array}$ & \multicolumn{5}{c}{$\begin{array}{c}\text { Average SNF equivalent enrichment level } \\
(\text { wt } \%)\end{array}$} \\
\cline { 2 - 6 } & 1.4 & 1.6 & 1.8 & 2.0 & 2.2 \\
\hline 0.5 & 1.15 & 1.31 & 1.46 & 1.62 & 1.78 \\
0.75 & 1.06 & 1.20 & 1.34 & 1.49 & 1.63 \\
1.0 & 0.98 & 1.11 & 1.24 & 1.38 & 1.51 \\
1.25 & 0.92 & 1.04 & 1.16 & 1.28 & 1.40 \\
1.5 & 0.87 & 0.98 & 1.09 & 1.20 & 1.31 \\
1.75 & 0.82 & 0.92 & 1.03 & 1.13 & 1.24 \\
2.0 & 0.78 & 0.88 & 0.98 & 1.07 & 1.17 \\
2.25 & 0.75 & 0.84 & 0.93 & 1.02 & 1.11 \\
\hline
\end{tabular}

${ }^{a}$ Assuming $9.689 \mathrm{t}$ of uranium in 21 PWR SNF assemblies and $5.155 \mathrm{~m}^{3}$ void space in loaded MPC. For highly loaded uranium glasses, the glass densities are $4-5 \mathrm{~g} / \mathrm{cm}^{3}$. Voids will occur between glass beads; hence, effective packing density will be $3-4 \mathrm{~g} / \mathrm{cm}^{3}$. Uranium densities in glass vary from 20 to $50 \mathrm{wt} \%$. Packing density is dependent upon the number of glass-bead sizes used. With optimum sizing, higher densities are possible.

\subsubsection{Impacts of Plutonium}

The foregoing analysis is based on the assumption that plutonium remains with the uranium until the plutonium decays to uranium and can be isotopically diluted by the DU. This is assured if the rate of plutonium decay to uranium is faster than the rate of dissolution and transport of uranium within the natural environment. The primary plutonium isotope, ${ }^{239} \mathrm{Pu}$, has a half-life of 24,000 years (i.e., the decay rate is $3 \times$ $10^{-5} /$ year).

The regulatory requirement (NRC 1995c) for waste package system performance is that the maximum allowable radionuclide release rate from the engineered barrier system shall not exceed $10^{-5} /$ year ( 1 part in $100,000 /$ year) of the inventory of that radionuclide calculated to be present at 1000 years following permanent repository closure. For a waste package system to meet regulatory requirements, it would be expected that most of the plutonium would have had to decay to uranium and that the fissile decay-product uranium would be isotopically diluted by the DU before significant quantities of uranium or plutonium leave the package. 
ORNL DWG 95A-583

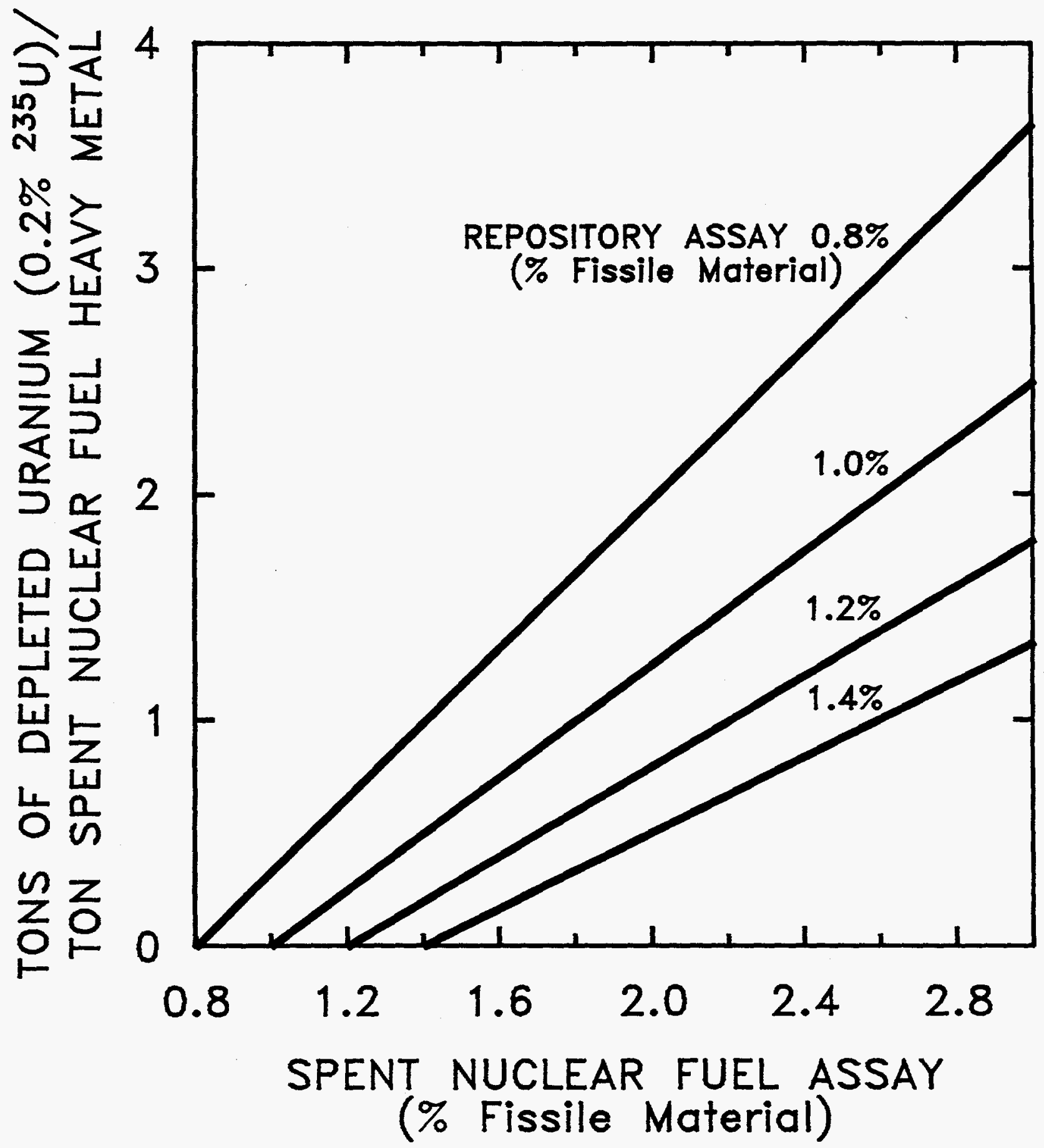

Fig. 8. Quantity of DU $\left(0.2 \%{ }^{235} U\right)$ required per metric ton of SNF heavy metal for different final repository enrichment levels. 
The experimental field data for naturally occurring reactors (Brookins 1984, McCombie and McKinley 1995, Brookins 1990, Von Maravic 1993, IAEA 1975, IAEA 1977) indicates that for most environments the plutonium will decay to uranium before the uranium or plutonium can be transported from the package. The uranium and plutonium within the package may however convert to more stable chemical forms within the package over the time frames of plutonium decay. Specific modelling studies of the proposed Yucca Mountain repository show very low release rates of plutonium and uranium in SNF (Sadeghi, Pigford, Chambre and Lee, October 1990). With such release rates, the plutonium will have converted to uranium long before significant releases of plutonium or uranium occur from the waste package system.

The premise that plutonium will not decay to uranium before uranium transport in the local geological environment must also be considered. In a geological repository using DUSCOBS, the local geological environment will become saturated with DU. This has longer term implications. If it is assumed that, in a particular waste package because of some special local conditions, the uranium partly separates from the plutonium before complete plutonium decay to uranium, then residual plutonium will decay to uranium and isotopically mix with the remaining uranium in the near-package environment. As this uranium is transported in the geological environment, it will most likely follow the flowpath of the uranium that was leached from the waste package earlier in time. This will bring it into contact with the uranium that was transported earlier. It will then be isotopically diluted by the DU in the local geological environment below enrichment levels at which nuclear criticality can occur.

This type of secondary mechanism does not provide absolute avoidance of nuclear criticality, but it decreases the probability of nuclear criticality in the repository. More importantly, it limits the maximum possible heat generation from nuclear criticality events. A local geological environment saturated with DU ensures that most of the enriched uranium is diluted below concentrations at which nuclear criticality can occur. This limits potential heat generation by limiting the potential quantities of higher fissile enrichment materials in the repository. These considerations suggest that it is beneficial to dispose of any excess DU (beyond what is needed within the waste package for DUSCOBS) within the same repository area where the SNF is being disposed of.

\subsection{REDUCED RADIATION INTERACTION WITH WASTE PACKAGE, WASTE PACKAGE CONTENT, AND NEAR-FIELD GEOLOGY}

Radiation degrades the performance of a repository because of multiple mechanisms. The most important mechanisms may be radiolysis of air and groundwater components (Finn, et al. 1994). Radiation interactions with air create nitrogen oxides that react with water to generate acids. Radiation interactions with 
water generate hydrogen that can embrittle and weaken SNF clad. These materials accelerate SNF and package corrosion. These mechanisms create incentives to minimize the potential air and groundwater content in the waste package as the package degrades and to provide internal shielding material to absorb the radiation within the waste package.

Backfilling the waste canister with DUS materials would provide an internal radiation shield. The DUS glass has a solid density between 4.5 and $7 \mathrm{~g} / \mathrm{cm}^{3}$ with an effective particulate density between 3 and $5 \mathrm{~g} / \mathrm{cm}^{3}$. This density would provide good gamma shielding capabilities. The backfill would also displace open space in the SNF assemblies, thus minimizing the volume available for air and groundwater available for interaction with radiation.

\subsection{CONTROLLED INTERNAL PACKAGE TEMPERATURE}

The use of DUSCOBS does not significantly change the temperature within a waste package. However, it provides higher assurance of what those temperatures are (Sect. 4.4) and that unexpected events will not alter those temperatures.

\subsection{REPOSITORY DESIGN TRADEOFF CONSIDERATIONS}

The optimum glass composition and particle size for DUSCOBS will depend upon specific design tradeoffs. For example, there is a trade-off in the size of the waste package. Large waste packages, such as the one consisting of an MPC with 21 PWR fuel assembles and an overpack, have the advantages of economics and of lower radionuclide release rates from the waste package over geological time. The lower release rates are possible because only so much water can flow by a single waste package. The dissolution of many fission products is solubility limited in groundwater. Furthermore, the dissolution and transport of uranium is limited by its solubility. The bigger waste package has less water flow by the package per metric ton of SNF.

However, large packages have two disadvantages: greater potential for nuclear criticality and potentially higher waste package temperatures due to higher SNF loadings. The advantages of a large package exist only if temperatures can be managed and nuclear criticality avoided. If large packages are chosen, then the optimum glass should have a high thermal conductivity to minimize package temperature, and the glass should be optimized to minimize the risk of nuclear criticality. The reverse is true for small packages. MPC backfills can address multiple repository concerns, but an emphasis on only one characteristic of the backfill will likely degrade capabilities in other areas. 
There are also tradeoffs in the choice of glass. A glass optimized for low radionuclide release rate from the waste package may have different properties than a glass optimized for avoidance of nuclear criticality. To optimize avoidance of nuclear criticality, the glass should have dissolution kinetics similar to SNF. To minimize radionuclide release rates, the DUS glass may be chosen to have faster dissolution kinetics than the SNF UO ${ }_{2}$. 


\section{MANAGEMENT OF DU}

At uranium enrichment plants in the United States, there are about $4 \times 10^{5} \mathrm{t}$ of DU, which is a by-product of nuclear fuel enrichment processes and weapons production. For LWR fuel production, natural uranium with a ${ }^{235} \mathrm{U}$ content of $0.71 \%$ is separated into a DU fraction and an enriched uranium fraction. The enriched uranium $\left(3-4 \%{ }^{235} U\right)$ is fabricated into fuel. Typically, 4 to 6 tons of DU are produced per ton of enriched uranium nuclear fuel. The current inventory of this material is shown in Table 9.

Table 9. DOE inventory of DU.

\begin{tabular}{cc}
$\begin{array}{c}{ }^{235} \mathbf{U} \text { assay } \\
(\mathbf{w t} \%)\end{array}$ & $\begin{array}{c}\text { Quantity of uranium } \\
(\mathbf{t})\end{array}$ \\
\hline$<0.21$ & 126,268 \\
$0.21-0.24$ & 5,271 \\
$0.24-0.26$ & 101,064 \\
$0.26-0.28$ & 3,482 \\
$0.28-0.31$ & 34,428 \\
$0.31-0.50$ & 94,886 \\
$0.50-0.60$ & 506 \\
$0.60-0.71$ & 3,601 \\
Total & 407,713 \\
\hline
\end{tabular}

Source: Hertzler, Nishimoto, and Otis, May 1994.

DOE has responsibility for management of this material and is examining options for its beneficial use. If this material is declared a waste, existing regulatory requirements indicate that some type of geological disposal will be required (NRC, January 1994), shallow land burial is unacceptable (NRC, September 22, 1992). The use of DU as a backfill material eliminates the cost of disposal of these materials. This provides a credit for use of DU package backfill material. Based on the analysis herein, a minimum of $25 \%$ of the inventory would be required to implement DUSCOBS-assuming the MPC is designed with minimum internal volume. 
If so desired, the MPC could be expanded to incorporate the total excess DU or the waste package could incorporate DUS glass. In the latter case, the DUS glass would replace conventional shielding within the waste package. It is noted that the use of DUS glass would further improve repository performance both in terms of reduced release of radionuclides from SNF and reduced potential for nuclear criticality. 


\section{ECONOMICS}

No economic assessment of this option has been conducted. There are multiple potential economic benefits but also potential costs. The potential areas for cost savings include: improved repository performance, simplified and more robust repository licensing case, simplified transport and storage cask design, elimination of the need to demonstrate SNF burnup credit for MPC operations, and avoidance of costs for disposal of DU. The costs are for those associated with implementation of DUSCOBS. Because (1) DUSCOBS uses empty space within the waste package that is now not used and (2) the disposal costs of DU may be high, there is a significant potential for systems cost savings. 


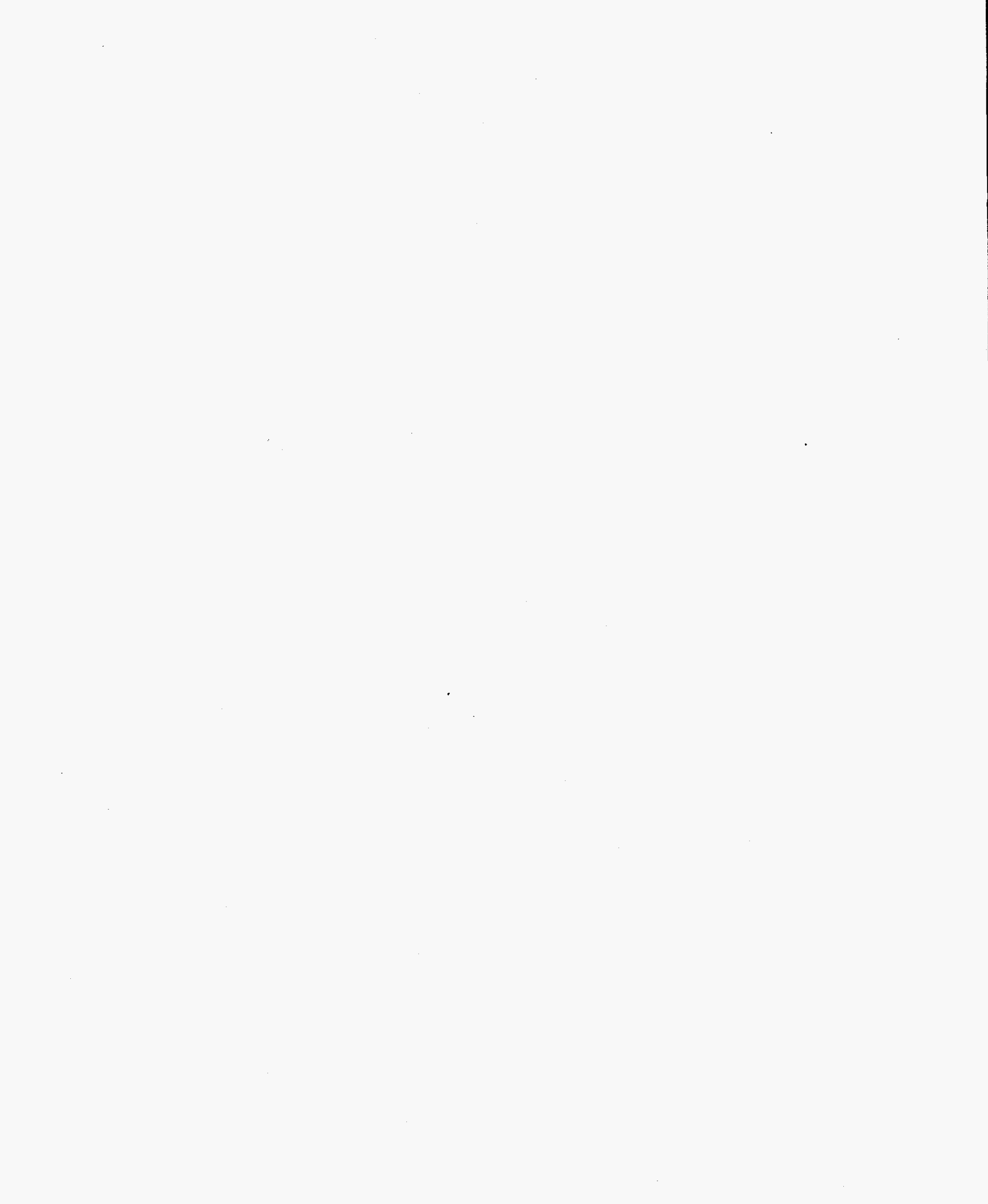

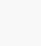
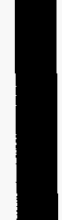


\section{UNCERTAINTIES}

The preliminary analysis herein is based on literature sources and limited calculations. No experiments have been conducted. Such information sources can provide a scientific basis for consideration of an advanced backfill material but by themselves can not quantify how much repository performance may improve or the impacts on transportation and storage. Benefits are strongly dependent on specific design details such as the glass composition, difficulty in demonstration of system performance improvements, costs to implement, time to implement, and other factors. Detailed analysis and experimental work are required to determine if the improvements in system performance are sufficient for the effort that must be expended to implement DUSCOBS.

The next step must include determination of the preferred composition or compositions of the DU backfill material. In this context, there may be trade-offs among the optimum glass to minimize radionuclide release rates, the optimum glass to minimize criticality concerns, and the optimum glass to minimize temperatures within the MPC. There will also be trade-offs among improved performance, cost, and ease of use. Appendix $\mathrm{E}$ lists issues that should be addressed.

There are also practical operational issues that must be understood. This includes preferred loading options for DUS glass beads, mechanisms to assure all void space is filled, and time required for various operations. Experiments with fuel assembly mock-ups will be required to validate any analysis. Practical operations issues may determine if DUS glass beads should be added at the reactor, a storage facility, or at the repository. There are trade-offs between transportation/storage benefits and complications in SNF loading at the reactor.

Beyond the scientific issues, a host of institutional issues such as licensing and economics exist. The benefits of DUSCOBS depends strongly upon reducing licensing uncertainty and obtaining the credits for disposal of DU wastes. 



\section{CONCLUSIONS}

The use of DUS glass as a backfill material for MPCs containing LWR SNF has multiple potential advantages:

- Improved repository performance with the potential for simplified repository licensing and higher assurance of system performance

- Reduced radionuclide release rates from the waste package

- Reduced potential for nuclear criticality

- Improved SNF transport and storage

- Elimination of the need for SNF burnup credit for maximum utilization of the large MPC.

- Improved performance of MPC during mechanical handling and in accident scenarios

- Disposition of excess DU.

Detailed analysis and experiments will be required to quantify these potential benefits, identify any liabilities, and estimate costs. 

 


\section{REFERENCES}

American National Standards Institute, October 7, 1983. American National Standard for Nuclear Criticality Safety in Operations with Fissionable Materials Outside Reactors, ANSUANS-8.1-1983, American Nuclear Society, La Grange Park, Illinois.

Benedict, M., and Pigford, T. H., 1957. Nuclear Chemical Engineering, McGraw-Hill Book Co., New York.

Brookins, D. G., 1990. "Radionuclide Behavior at the Oklo Nuclear Reactor, Gabon," Waste Management, 10:285.

Brookins, D. G., 1984. Geochemical Aspects of Radioactive Waste Disposal, Springer-Verlag, New York.

Bowman, C. D., and Venneri, F., 1994. Underground Autocatalytic Criticality from Plutonium and Other Fissile Materials, LA-UR 94-4022, Los Alamos National Laboratory, Los Alamos, New Mexico.

Bruton, C. J., and Shaw, H., 1988. "Geochemical Simulation of Reaction Between Spent Fuel Waste Form And J-13 Water at $25^{\circ} \mathrm{C}$ and $90^{\circ} \mathrm{C}$," p. 485 in Scientific Basis for Nuclear Waste Management XI, eds. M. J. Apted and R. E. Westerman, Materials Research Society, Pittsburgh, Pennsylvania.

Buscheck, T. A., and Nitao, J. J., December 1993. "Repository-Heat-Driven Hydrothermal Flow at Yucca Mountain, Part I,"Nucl. Tech., 104(3),418.

Buscheck, T. A., Nitao, J. J., and Wilder, D. G., December 1993. "Repository-Heat-Driven Hydrothermal Flow at Yucca Mountain, Part II,"Nucl. Tech., 104(3):449.

Chakrabarty, M. R, 1969. "Formation and Properties of Uranium Glasses," American Ceramic Society Bulletin, 48(11):1076.

Cowan, G. A., July 1976. “A Natural Fission Reactor," Scientific American, 235.36.

Dean, J. A., 1973. Lange's Handbook of Chemistry: Eleventh Edition, McGraw Hill Book Co., New York.

Finn, P. C., et al., 1994. "Elements Present in Leach Solutions from Unsaturated Spent Fuel Tests," p. 399 in Proc. Mat. Res. Soc. Symp., Vol. 333.

Finn, P. A., Gong. M., Bates, J. K., Emery, J. W., and Hoh, J. C., May 1994. "The Effect of Fuel Type in Unsaturated Spent Fuel Tests," p. 1080 in Proc. Fifth Ann. Int. Conf. High-Level Radioactive Waste Management, Las Vegas, Nevada, May 22-26, 1994, American Nuclear Society, La Grange Park, Illinois.

Finn, P. A., Hoh, J. C., Bates, J. K., and Wolf, S. F., December 1994. "Behavior of Spent Fuel Under Unsaturated Conditions," p. 421 in Proc. Topical Meeting. DOE Spent Nuclear Fuel-Challenges and Initiatives, Salt Lake City, Utah, December 13-16, 1994, American Nuclear Society, La Grange Park, Illinois. 
Hertzler, T., Nishimoto, D. D., and Otis, M. D., May 1994. Depleted Uranium Disposal Options Evaluation, EGG-MS-11297, Idaho National Engineering Laboratory, Idaho Falls, Idaho.

International Atomic Energy Agency, 1975. The Oklo Phenomenon, Proc. of a Symposium, Libreville, June 23-27, 1975, Vienna, Austria.

International Atomic Energy Agency, 1977. Natural Fission Reactors, Proc. of a Mtg. of the Technical Committee on Natrual Fission Reactors, Paris France, December 19-21, 1977, Vienna, Austria.

Johnson, L. H., and Shoesmith, D. W., 1988. "Spent Fuel," in Radioactive Waste Forms For The Future, edited by W. Lutze and R. C. Ewing, Elsevier. Amsterdam.

Ludwig, S. B., and Renier, J. P., December 1989. Standard-and Extended-Burnup PWR and BWR Reactor Models for the ORIGEN2 Computer Code, ORNL/TM-11018, Martin Marietta Energy Systems, Inc., Oak Ridge National Laboratory, Oak Ridge, Tennessee.

McCombie, C., and McKinley, I., May 1995. "Cigar Lake: A Natural Example of Long-Term Isolation of Uranium," Radwaste Magazine, 2(3):36.

Moore, W. J., 1962. Physical Chemistry, Prentice-Hall, Inc., Englewood Cliffs, New Jersey.

Nicol, M. J., and Needes, C. R. S., 1975. "The Anodic Dissolution of Uranium Dioxide-I. in Perchlorate Solutions," Electrochim. Acta, 20:585.

Nicol, M. J., and Needes, C. R. S., 1977. "The Anodic Dissolution of Uranium Dioxide-II. in Carbonate Solutions," Electrochim. Acta, 22:1381.

Naudet, S. R, 1977. "Etude Parametrique De La Criticite Des Reacteur Naturels," Natural Fission Reactors, Proc. of a Meeting of the Technical Committee on Natural Fission Reactors, Paris, France, December 19-21, 1977, International Atomic Energy Agency, Vienna, Austria.

Patric, L. W., and McDonell, W. R., March 6, 1992. Action Plan No. REP-7: NPR Spent Nuclear Fuel Disposal Studies and Program to Resolve Disposal Cost Questions, Westinghouse Savannah River Company, Aiken, South Carolina.

Paxton, H. C., and Pruvost, N. L., July 1987. Critical Dimensions of Systems Containing ${ }^{235} U$, ${ }^{239} P u$, and ${ }^{233} U$ : 1986 Revision, Los Alamos National Laboratory, Los Alamos, New Mexico.

Ramsey, W. G., 1994. "Composition and Durability of Glasses for Immobilization of Plutonium and Uranium," in Proc. Waste Management '95, February 28-March 2, 1995, Tucson, Arizona, American Nuclear Society, La Grange Park, Illinois.

Rechard, R. P., et al., 1993. Initial Performance Assessment of the Disposal of Spent Nuclear Fuel and High-Level Waste Stored at Idaho National Engineering Laboratory, SAND93-2330, Sandia National Laboratory, Albuquerque, New Mexico. 
Sadeghi, M. M., Pigford, T. H., Chambre, P. L., and Lee, W. W. L., October 1990. Prediction of Release Rates for a Potential Waste Repository at Yucca Mountain, LBL-27767, Lawrence Berkeley Laboratory, University of California, Berkeley, California.

Shoesmith, D. W., Sunder, S., Bailey, M. G., and Wallace, G. J., 1988. "Anodic Oxidation of $\mathrm{UO}_{2}$ : Electrochemical and X-ray Photoelectron Spectroscopic Studies of Film-Growth and Dissolution in Phosphate-Containing Solutions," Can. J. Chem, 66,259.

Smellie, J., March 1995. “The Fossil Nuclear Reactors of Oklo, Gabon,” Radwaste Mag., 2(2),18.

U.S. Department of Energy, Office of Civilian Radioactive Waste Management, September 1994. MultiPurpose Canister System Evaluation: A Systems Engineering Approach, Washington, D.C.

U.S. Nuclear Regulatory Commission, September 22, 1992. Letter from John W. N. Hickey, Chief Fuel Cycle Safety Branch, U.S. Nuclear Regulatory Commission To Louisiana Energy Services, L. P., Docket No. 70-3070, U.S. Nuclear Regulatory Commission, Washington, D.C. 20555.

U.S. Nuclear Regulatory Commission, January 1994. Safety Evaluation Report for the Claiborne Enrichment Center, Homer, Louisiana, Docket No. 70-3070, NUREG-1491, Washington, D.C.

U.S. Nuclear Regulatory Commission, 1995a. "General Requirements For All Fissile Materials Packages," Code of Federal Regulations 10 CFR 71.55., Washington D.C.

U.S. Nuclear Regulatory Commission, 1995b. Code of Federal Regulations, 10 CFR 60.131.

U.S. Nuclear Regulatory Commission, 1995c. Code of Federal Regulations, 10 CFR 60.113(a)(1)(ii)(B), Washington D.C.

Vernaz, E. Y., and Godon, N., 1992. "Leaching of Actinides From Nuclear Waste Glass: French Experience," Scientific Basis for Nuclear Waste Management XV, ed. C Sombret, 87, Materials Research Society, Pittsburgh, Pennsylvania.

Von Maravic, H., 1993. Oklo Working Group Meeting: Proceedings of the Second Joint CEC-CEA Progress Meeting Held in Brussels, April 6-7, 1992, EUR 14877, Commission of the European Communities, Brussels, Belgium.

Wronkiewicz, D. J., et al., 1992. "Uranium Release and Secondary Phase Formation During Unsaturated Testing of $\mathrm{UO}_{2}$ at $90^{\circ} \mathrm{C}$, " J. of Nuclear Materials, 190:107. 
Appendix A:

CHARACTERISTICS OF MPC AND LWR SNF 



\section{Canister}

Geometry

Capacity (PWR assemblies)

Outside diameter, $\mathrm{cm}$

Wall thickness, $\mathrm{cm}$

Inside diameter, $\mathrm{cm}$

Outside height, $\mathrm{cm}$

Lid thickness, $\mathrm{cm}$

Bottom thickness, $\mathrm{cm}$

Inside height, $\mathrm{cm}$

Internal volume, $\mathrm{m}^{3}$

Fuel Basket Type A

Assemblies/basket

Geometry

Number of baskets/canister

Outside width, cm

Inside, width, $\mathrm{cm}$

Height, cm

Metal volume/basket, $\mathrm{m}^{3}$

Fuel Basket Type B

Assemblies/basket

Number of baskets/canister

Outside geometry

Width, $\mathrm{cm}$

Depth, cm

Inside geometry

Width, $\mathrm{cm}$

Height, cm

Metal volume/basket, $\mathrm{m}^{3}$

Source: DOE 1994b.
Right cylinder

21

153.2

2.54

148.1

490.2

26.7

6.35

457.2

7.876

1

Square

9

406.4

0.0586

1

12

Rectangle

25.37

24.50

Square

22.35

406.4

0.0496 
Table A.2 Reference PWR nuclear fuel assembly

Height, cm

Cross section, $\mathrm{cm}$

Width, cm

Uranium/assembly, $\mathrm{kg}$

Fuel rods

Number

Rod diameter, $\mathrm{cm}$

Rod length, $m$

Volume/rod, $\mathrm{cm}^{3}$

Assembly Hardware

Zircaloy mass minus clad, $\mathrm{kg}$

Zircaloy density, $\mathrm{g} / \mathrm{cm}^{3}$

Zircaloy volume, $\mathrm{cm}^{3}$

Stainless steel mass, $\mathrm{kg}$

Stainless steel density, $\mathrm{g} / \mathrm{cm}^{3}$

Stainless steel volume, $\mathrm{cm}^{3}$

Fuel Assembly Solid Volume

Rods, $\mathrm{m}^{3}$

Zircaloy, $\mathrm{m}^{3}$

Stainless steel, $\mathrm{m}^{3}$

Total, $\mathrm{m}^{3}$

$$
4.059
$$

Square

21.4

461.4

264

0.95

3.851

273.0

4.1

6.4

640.0

26.1

7.8

$3,346.0$

0.00064

0.00335

0.0761

Sources: DOE 1994b, Roddy, 1986. 


\section{A.1 REFERENCES}

Roddy, J. W., et al., January 1986. Physical and Decay Characteristics of Commercial LWR Spent Fuel, ORNL/TM-9591/V1\&R1, Union Carbide Corporation-Nuclear Division, Oak Ridge National Laboratory, Oak Ridge, Tennessee.

U.S. Department of Energy, March 1994. Integrated Data Base for 1993: U.S. Spent Fuel and Radioactive Waste Inventories, Projections, and Characteristics, DOE/RW-0006, Rev. 9, Washington D.C.

U.S. Department of Energy, September 1994. Multi-Purpose Canister System Evaluation: A Systems Engineering Approach, DOE/RW-0445, Washington D.C. 

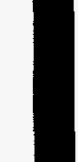
Appendix B:

CRITICALITY AND SHIELDING ANALYSIS OF DUSCOBS 


\section{APPENDIX B: CRITICALITY AND SHIELDING ANALYSIS OF DUSCOBS}

\section{B.1 INTRODUCTION}

The SCALE-4 code system (NRC, April 1995) was used for all criticality and shielding analyses performed in support of this work. SCALE is well-established and has been widely used in AFR applications for (a) criticality safety analysis via the CSAS25 sequence and (b) shielding via the SAS4 sequence. This appendix provides a technical description of the approaches used and assumptions made in the study of the effect of DUS backfill in an LWR SNF waste package.

The main body of this appendix is divided into five sections, each dedicated to a specific aspect of the physics analyses of a conceptual DUS application: (1) overview of the SCALE system, (2) cask model and composition assumptions, (3) criticality calculations, (4) shielding calculations, and (5) discussion of results.

\section{B.2 OVERVIEW OF THE SCALE-4 SYSTEM}

The SCALE-4 system provides a number of different calculational sequences; for this work the CSAS25 sequence (Landers and Petrie, April 1995) was used in criticality calculations, the SAS2H sequence (Hermann and Parks, 1995) was used for fuel depletion computations, and the SAS4 sequence (Tang 1995) was applied in shielding analyses. The CSAS25 analytical sequence provides a simplified method for performing multidimensional neutron multiplication factor $\left(k_{\text {eff }}\right)$ analyses using the KENO V.a Monte Carlo code (Petrie and Landers, 1995). The SAS4 sequence performs automated baising for the MORSE-SGC (West, Hoffman, and Emmett, 1995) Monte Carlo simulation of radiation transport in shielding designs. SAS2H automates the iterative procedure of cross-section processing, cell weighting, flux spectrum calculations, and point-depletion analysis to predict the isotopic concentration of SNF.

Each of the SCALE sequences invokes a standardized procedure to provide appropriate cross-sections to use in subsequent transport calculations. This procedure begins with the SCALE Material Information Processor (Landers, Petrie, and Bucholz, April 1995), which generates number densities and related information, prepares geometry data for resonance self-shielding and flux-weighting cell calculations, and creates data input for the cross-section processing codes. Cross-section processing is performed by sequentially activating the BONAMI (Greene, April 1995) and NITAWL-II (Greene, Petrie, and Westfall, April 1995) codes. BONAMI applies the Bondarenko method of resonance self-shielding for nuclides that have Bondarenko data included in their cross-section libraries. NITAWL-II performs Nordheim resonance self-shielding corrections for nuclides that have resonance parameters included in their cross-section data. Resonance-corrected microscopic cross sections are created in AMPX working library format (Greene, Ford, Petrie, and Arwood, October 1992). 


\section{B-4}

In CSAS25 calculations, the computed material mixtures and cross-section library are combined with user-specified geometry descriptions to complete a KENO V.a criticality model. KENO V.a is then invoked to compute the estimated value of $k_{\text {eff }}$ for the specified system.

The SAS2H sequence uses a three-step procedure to produce time-dependent isotopic concentrations. First, the one-dimensional (1-D) deterministic transport code XSDRNPM (Greene and Petrie, April 1995) is used to provide cell-weighted cross sections; these cross sections are then passed to an XSDRNPM assembly calculation (i.e., a 1-D radial approximation of an assembly design). The assembly calculation produces zone-dependent (i.e., fuel, clad, and moderator) neutron-flux spectra used to collapse multigroup cross sections into a single group representing assembly averaged conditions. Finally, these one-group cross sections are used in an ORIGEN-S (Hermann and Westfall, April 1995) point-depletion calculation to obtain time-dependent isotopic concentrations. Resonance processing is then performed based on the revised isotopic composition of the fuel, and the depletion process is repeated. This procedure is continued in userdefined time-steps until the desired depletion state has been reached. The isotopic concentrations resulting from this analysis may then be used in the input specifications of a subsequent spent fuel calculation. In addition to isotopic results, SAS2H provides (a) multigroup neutron and gamma source spectra to use in shielding analyses and (b) decay-heat source terms for use in thermal analyses.

In SAS4 calculations, the 1-D deterministic transport code XSDRNPM is used to provide cell-weighted cross sections during cross-section processing procedures. It is also used to perform an adjoint calculation to generate biasing parameters for the subsequent MORSE-SGC calculation; these parameters are essential to obtain accurate estimates of radiation dose rates in typical cask-shielding calculations. Finally, SAS4 invokes MORSE-SGC to provide an estimate of dose rates exterior to a spent-fuel cask based on a user-specified cask configuration; a built-in cask model within SAS4 simplifies the process of describing the cask geometry.

\section{B.3 LWR SPENT FUEL CASK CONFIGURATION}

For this study, numerical models were developed based on a 125-ton MPC design (DOE, 1994). This conceptual design accommodates up to 21 PWR spent fuel assemblies. DUS analyses were performed which assumed that all 21 positions were filled with identical fuel assemblies.

The fuel assembly design was assumed to be of the Westinghouse $17 \times 17$ design. Fuel design data are listed in Table B.1. For conservatism, all criticality calculations assumed fresh fuel (i.e., no credit was taken for the depletion of fissile isotopes and the collateral production of activation and fission-product poisons). Fuel enrichments of both 3.75 and $5.0 \mathrm{wt} \%{ }^{235} \mathrm{U}$ were used in criticality analyses. Shielding calculations were based on a design-basis enrichment of $3.75 \mathrm{wt} \%$ with a 40-GWd/MTU burnup (DOE, 1994); depletion and source-term calculations were performed using the SAS2H sequence of SCALE. Assumed depletion parameters are provided in Table B.2. 
B-5

Table B.1. Westinghouse $17 \times 17$ fuel assembly design specifications

\begin{tabular}{lc}
\multicolumn{1}{c}{ Parameter } & Data \\
\hline Fuel rod data & \\
Fuel diam, cm & 0.81918 \\
Clad inner diam, cm & 0.83566 \\
Rod outer diam, cm & 0.94996 \\
Fuel length, cm & 365.76 \\
Fuel material & UO 2 (95\% theoretical density) \\
Clad material & Zircaloy \\
Gas gap material & Void \\
Control rod guide tube data & \\
Inner diam, cm & 1.12268 \\
Outer diam, cm & 1.20396 \\
Tube material & Zircaloy \\
Instrumentation guide tube data & \\
Inner diam, cm & $1.25984 \mathrm{~cm}$ \\
Outer diam, cm & \\
Tube material & 1.12776 \\
Assembly data & 1.20904 \\
Lattice & Zircaloy \\
Number of fuel rods & \\
Number of $\mathrm{C} / \mathrm{R}$ guide tubes & \\
Number of instrumentation tubes & \\
\hline & \\
\hline & \\
Lattice pitch & \\
\hline
\end{tabular}


B-6

Table B.2. Assumed reactor conditions for depletion calculations

\begin{tabular}{lc}
\hline \multicolumn{1}{c}{ Parameter } & Data \\
\hline Fuel temperature & $894 \mathrm{~K}$ \\
Clad temperature & $628 \mathrm{~K}$ \\
Moderator temperature & $569 \mathrm{~K}$ \\
Moderator density & $0.735 \mathrm{~g} / \mathrm{cm}^{3}$ \\
Average boron concentration & $450 \mathrm{ppm}$ \\
Cycle burnup & $40 \mathrm{GWd} / \mathrm{MTU}$ \\
Burnup history & $1080 \mathrm{~d}$ constant power \\
\hline
\end{tabular}

For both shielding and criticality studies, calculations were performed both with and without DUS sand present within the cask. Models with sand present were based on a soda-lime sand with a $25 \mathrm{wt} \%$ content of DU $\left(0.2\right.$ wt $\left.\%{ }^{235} \mathrm{U}\right)$. This composition was felt to be most conservative in terms of criticality analysis because it contains no boron. (Other candidate DUS sands that contain boron would result in increased neutron poisoning resulting from the presence of strongly absorbing boron and would therefore result in lower values of $k_{\text {eff. }}$ ) The complete composition of the sand is described in Table B.3. Based on this composition, the sand density was determined to be $4.1 \mathrm{~g} / \mathrm{cm}^{3}$. The sand was assumed to occupy all void space within a fully loaded (i.e., 21 assemblies) MPC shell with a packing density of $65 \mathrm{vol} \%$ sand, 35 vol \% void. Criticality calculations performed with water present were assumed to contain 65 vol \% sand and 35 vol \% water throughout.

\section{B.4 CRITICALITY CALCULATIONS}

All criticality calculations were based on 3-D KENO V.a models of an MPC configuration described previously. Each fuel pin, control-rod guide tube, and instrumentation guide tube was modeled explicitly within an assembly model; the assembly was centered within an aluminum-boron basket position. Guide tubes were assumed to be void within the tube; fuel rod models included a gas gap between fuel and cladding. Lower region assembly hardware was assumed to extend $10 \mathrm{~cm}$ below the active fuel length, and the upper hardware length was assumed to be $30 \mathrm{~cm}$. Rather than attempting to model the details of the hardware design, the hardware regions were assumed to be an homogenous mixture of $50 \%$ void space and $50 \%$ SS-304. In addition, grid spacers located within the active length of the fuel rod were neglected. 


\section{B-7}

Table B.3. Composition of DU silicate glass

\begin{tabular}{|c|c|}
\hline Material & Wt \% in sand \\
\hline \multicolumn{2}{|l|}{ Component data } \\
\hline $\mathrm{U}_{3} \mathrm{O}_{8}$ & 29.4804 \\
\hline $\mathrm{CaO}$ & 11.1655 \\
\hline $\mathrm{Na}_{2} \mathrm{O}$ & 7.4045 \\
\hline $\mathrm{SiO}_{2}$ & 51.9491 \\
\hline \multicolumn{2}{|l|}{ Isotopic data } \\
\hline $\mathrm{U}$ & 25.000 \\
\hline${ }^{234} \mathrm{U}$ & $0.00035(0.0014 \mathrm{wt} \%$ in $U)$ \\
\hline${ }^{235} \mathrm{U}$ & $0.05000(0.2000$ wt $\%$ in $U)$ \\
\hline${ }^{236} \mathrm{U}$ & $0.00023(0.0009 w t \%$ in $U)$ \\
\hline${ }^{238} \mathrm{U}$ & $24.9492(99.7977 \mathrm{wt} \%$ in $U)$ \\
\hline $\mathrm{Ca}$ & 3.186 \\
\hline $\mathrm{Na}$ & 1.911 \\
\hline $\mathrm{Si}$ & 27.666 \\
\hline 0 & 37.244 \\
\hline
\end{tabular}

Because design-basis accident analyses of LWR spent fuel configurations are based on an assumed flooded state to maximize fuel reactivity, calculations were performed with either air (void) or water within otherwise unoccupied regions of the cask (with the exception of the void region representing the gas gap within a fuel rod, this region was always assumed void). Thus, for each of the two enrichments studied ( $3.75 \mathrm{wt} \%$ and $5.0 \mathrm{wt} \%$ ), a total of four different calculations were performed, representing casks both with and without DUS sand present, and both with and without water filling interstitial void space. Calculations were performed on an IBM RS/6000 workstation using SCALE Version 4.3 and the SCALE fine-structure, ENDF/B-V-based, 238-group, cross-section library. Results are given in Table B.4 for a 3.75-wt \% fresh fuel loading and in Table B.5 for a 5.0-wt \% fresh fuel loading. The calculated value of $k_{\text {eff }}$ is given, together 
B-8

Table B.4. Results of criticality calculations for 3.75 wt $\%$ fresh fuel

\begin{tabular}{lcc}
\hline Filler material & $\begin{array}{c}\boldsymbol{k}_{\text {eff }} \\
\left(\boldsymbol{k}_{\text {eff }}+\mathbf{3} \boldsymbol{\sigma}\right)\end{array}$ & $\begin{array}{c}\text { Average energy at which } \\
\text { fission occurs (AEF) (eV) } \\
(\mathbf{A E F} \pm \boldsymbol{\sigma})\end{array}$ \\
\hline Air & $\begin{array}{c}0.3782 \pm 0.0004 \\
(0.3794)\end{array}$ & $118,812 \pm 452$ \\
65 vol \% DUS/35 vol \% air & $\begin{array}{c}0.3920 \pm 0.0003 \\
(0.3929)\end{array}$ \\
Water & $\begin{array}{c}1.0819 \pm 0.0007 \\
(1.0840)\end{array}$ & $31,970 \pm 119$ \\
65 vol \% DUS/35 vol \% water & $0.7226 \pm 0.0006$ \\
\end{tabular}

Table B.5. Results of criticality calculations for $5.00 \mathrm{wt} \%$ fresh fuel

\begin{tabular}{lcc} 
Filler material & $\begin{array}{c}\boldsymbol{k}_{\text {eff }} \\
\left(\boldsymbol{k}_{\text {eff }}+3 \text { o) }\right.\end{array}$ & $\begin{array}{c}\text { AEF }(\mathrm{eV}) \\
(\mathrm{AEF} \pm \boldsymbol{\sigma})\end{array}$ \\
\hline Air & $\begin{array}{c}0.4383 \pm 0.0004 \\
(0.4395)\end{array}$ & $103,345 \pm 363$ \\
65 vol \% DUS/35 vol \% air & $0.4577 \pm 0.0003$ & \\
& $(0.4586)$ & $27,517 \pm 89$ \\
Water & $\begin{array}{c}1.1428 \pm 0.0007 \\
(1.1449)\end{array}$ & $0.3406 \pm 0.0010$ \\
65 vol \% DUS/35 vol \% water & $0.7797 \pm 0.0006$ & \\
& $(0.7815)$ & $6.7830 \pm 0.030$ \\
\hline
\end{tabular}


with its uncertainty at a 67\% (1 $\sigma)$ confidence level. Parenthetically listed with the calculated result is the expected upper bound on the calculated value of $k_{\text {eff }}$ at a $99 \%(3 \sigma)$ confidence level. Also listed in each table is the AEF, a parameter which indicates the approximate energy range in which most neutrons fission and which can be used to characterize the energy spectrum of the system. Note that the water-filled cask is a thermal system, while the dry ones are epithermal systems with average energies in the resonance range. The cask filled with water and sand, however, is at the upper end of the thermal range and thus would possess a significant fraction of resonance-region fissions.

\section{B.5 SHIELDING CALCULATIONS}

All shielding calculations were based on 3-D SAS-4 models of the MPC configuration described earlier. Depletion and source-term calculations were performed using ORIGEN-S within the SAS2H sequence of SCALE. Assembly compositions were based on the same Westinghouse $17 \times 17$ assembly design used in criticality calculations; however, material properties and source terms were homogenized over the volume of the assembly because the geometry of the fuel pin lattice has little effect on cask shielding calculations. Cask models included 21 assembly units; cask and basket specifications were modeled explicitly. Each assembly was assumed to be identical in terms of composition and source terms.

Design-basis shielding limits are determined under dry-cask conditions. Thus, calculations were performed assuming full cask loading with and without DUS backfill. Assembly properties were determined assuming (a) $100 \%$ void in interstitial regions of the assembly for empty (no sand) conditions and (b) $65 \%$ sand and $35 \%$ void for backfilled conditions. Gamma-ray and neutron source terms were calculated based on 3.75-wt \% enriched fuel, an assumed burnup of $40 \mathrm{GWd} / \mathrm{MTU}$, and a 10-year cooling time (DOE, 1994). Calculations were performed on an IBM RS/6000 workstation using SCALE Version 4.3 and the SCALE coupled 27-group neutron/18-group gamma-ray cross-section library. Dose response functions were obtained from the ANSI/American Nuclear Society (ANS)-6.1.1 1977 standard. Dose rates were calculated at a radial distance of $2 \mathrm{~m}$ from the cask wall, at the axial centerline of the fuel length, for azimuthal angles of 0 and $30.96^{\circ}$. Figure B.1 illustrates the orientation of the cask relative to the reference coordinate system. The $0^{\circ}$ rotation angle represents the location which sees the largest source area, while the $30.96^{\circ}$ rotation represents the closest approach of the source region to the dose point. Calculations were performed to determine point dose rates $(\mathrm{mrem} / \mathrm{h}$ ) resulting from neutrons, primary gamma rays (emitted as the result of fission-product and activation-product decay), and secondary gamma rays (produced as the result of $n-\gamma$ reactions). 


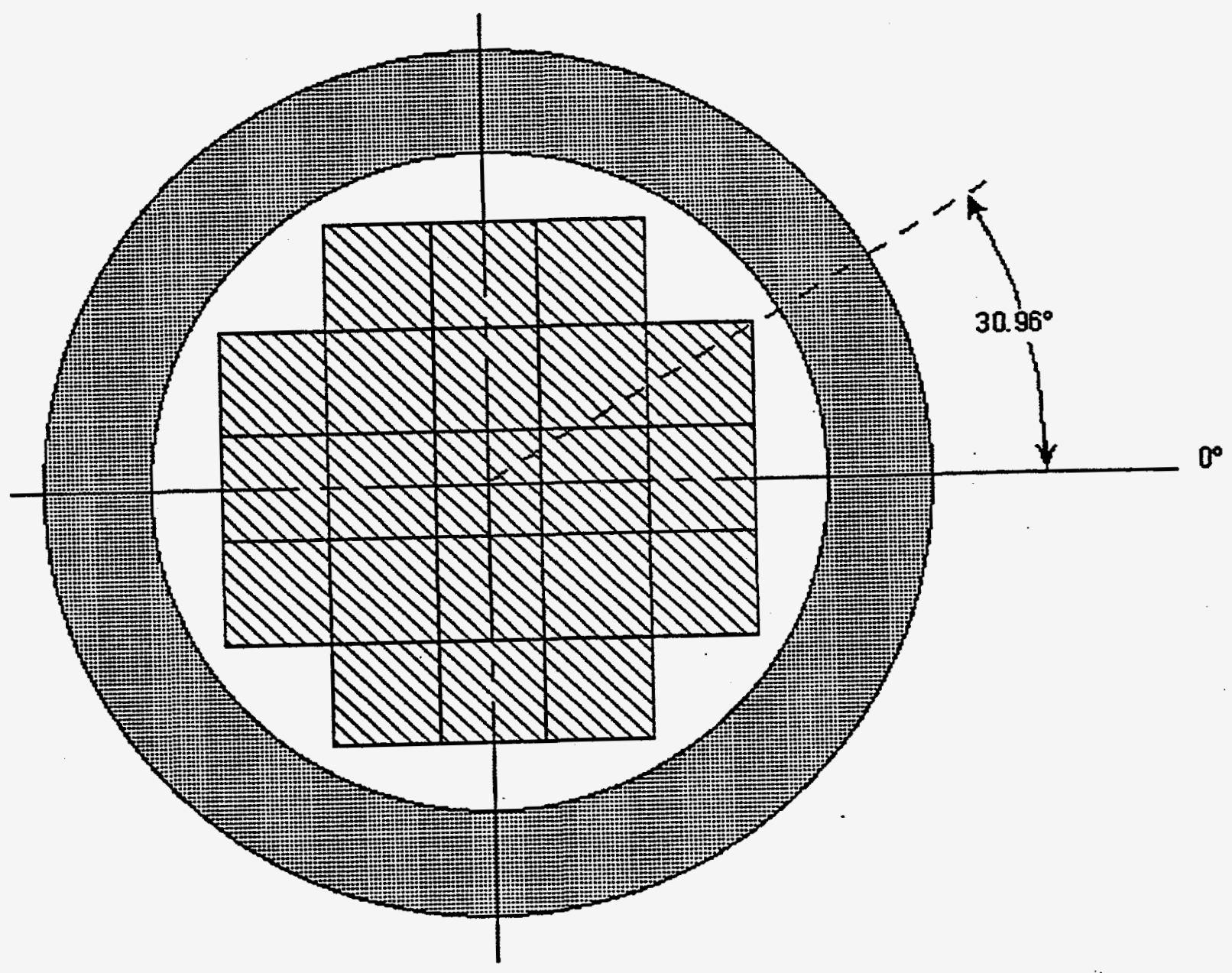

Fig. B.1. Model for shielding calculations. 


\section{B-11}

Shielding calculations were performed to assess two considerations. First, shielding calculations were used to determine the reduction in radiation dose caused by the use of a DUS backfill relative to a nonbackfilled cask. Second, calculations were performed to determine which portions of the cask shielding could be removed (to offset the increased cask mass resulting from DUS glass backfill) such that the nominal nosand dose would not be exceeded. Thus, in addition to no-sand and sand-filled configurations, cask models were evaluated for three sand-filled configurations with various reductions in cask shield materials: (1) radial lead shield removed, (2) $15 \%$ of radial DU shield removed, and (3) $25 \%$ of radial DU shield removed. These components were selected because of their high density. Results for each configuration are provided in Tables B.6 through B.8 for neutron, primary gamma-ray, and secondary gamma-ray doses, respectively.

Table B.6. Results of cask shielding calculations of neutron dose

\begin{tabular}{lcc}
\hline \multicolumn{1}{c}{ Cask model } & \multicolumn{1}{c}{$\begin{array}{c}\text { Dose at 0 } \\
\text { (mrem/h) }\end{array}$} & $\begin{array}{c}\text { Dose at 30.96 } \\
(\mathbf{m r e m} / \mathbf{h})\end{array}$ \\
\hline 21-element cask, no backfill, nominal shield design & $0.51071 \pm 6.49 \%$ & $0.57425 \pm 10.52 \%$ \\
21-element cask, DUS backfill, nominal shield design & $0.23096 \pm 14.75 \%$ & $0.29822 \pm 26.8 \%$ \\
21-element cask, DUS backfill, no radial lead shield & $0.28315 \pm 28.8 \%$ & $0.28730 \pm 5.76 \%$ \\
21-element cask, DUS backfill, no radial lead shield, & & \\
85\% of nominal DU shield & $0.21421 \pm 5.38 \%$ & $0.27272 \pm 22.0 \%$ \\
21-element cask, DUS backfill, no radial lead shield, & & \\
75\% of nominal DU shield & $0.28755 \pm 17.0 \%$ & $0.28744 \pm 11.1 \%$ \\
\hline
\end{tabular}

Table B.7. Results of cask shielding calculations of primary gamma-ray dose

\begin{tabular}{lcc}
\hline \multicolumn{1}{c}{ Cask model } & $\begin{array}{c}\text { Dose at } 0^{\circ} \\
(\mathbf{m r e m} / \mathbf{h})\end{array}$ & $\begin{array}{c}\text { Dose at 30.96 } \\
(\mathbf{m r e m} / \mathbf{h})\end{array}$ \\
\hline 21-element cask, no backfill, nominal shield design & $5.0572 \pm 6.01 \%$ & $4.1154 \pm 2.65 \%$ \\
21-element cask, DUS backfill, nominal shield design & $0.92514 \pm 5.12 \%$ & $0.99892 \pm 8.17 \%$ \\
21-element cask, DUS backfill, no radial lead shield & $2.2909 \pm 9.68 \%$ & $2.6116 \pm 14.1 \%$ \\
21-element cask, DUS backfill, no radial lead shield, & & \\
85\% of nominal DU shield & $4.5765 \pm 9.13 \%$ & $5.4230 \pm 10.8 \%$ \\
21-element cask, DUS backfill, no radial lead shield, & & \\
75\% of nominal DU shield & $6.3896 \pm 8.53 \%$ & $6.9364 \pm 11.2 \%$ \\
\hline
\end{tabular}


Table B.8. Results of cask shielding calculations of secondary gamma-ray dose

\begin{tabular}{lcc}
\hline \multicolumn{1}{c}{ Cask model } & $\begin{array}{c}\text { Dose at } 0^{\circ} \\
(\mathbf{m r e m} / \mathbf{h})\end{array}$ & $\begin{array}{c}\text { Dose at 30.96 } \\
(\mathbf{m r e m} / \mathbf{h})\end{array}$ \\
\hline 21-element cask, no backfill, nominal shield design & $1.6857 \pm 5.14 \%$ & $1.6495 \pm 2.65 \%$ \\
21-element cask, DUS backfill, nominal shield design & $0.70343 \pm 2.65 \%$ & $0.72877 \pm 3.42 \%$ \\
21-element cask, DUS backfill, no radial lead shield & $0.72191 \pm 3.48 \%$ & $0.70970 \pm 3.13 \%$ \\
21-element cask, DUS backfill, no radial lead shield, & & \\
85\% of nominal DU shield & $0.84666 \pm 5.69 \%$ & $0.83852 \pm 5.81 \%$ \\
21-element cask, DUS backfill, no radial lead shield, & & \\
75\% of nominal DU shield & $0.98777 \pm 11.7 \%$ & $0.82675 \pm 1.80 \%$ \\
\hline
\end{tabular}

The calculated dose rates are given together with the corresponding percentage uncertainty at a 10 confidence level. The estimated total dose rate from all contributions are given in Table B.9.

\section{B.6 DISCUSSION}

The calculations have demonstrated that from a criticality perspective a DUS-filled cask is far from critical under both dry and wet conditions. Shielding calculations show that a marked decrease in external doses is observed for a dry cask filled with DUS and that some of the shielding may be removed from the original design to offset the original cask design. However, these results indicate that additional work will be required to determine if a fully optimized system weight with DUSCOBS would be as low or lower than a system without DUSCOBS. The following subsections discuss the results of each set of analyses.

\section{B.6.1 Criticality Analysis}

The recommended approach for establishing subcriticality based on the numerical calculation of the neutron multiplication factor is prescribed in Sect. 5.1 of ANSI/ANS-8.17 (ANSI, 1984). This criterion requires that the calculated multiplication factor for an acceptably subcritical system, $k_{s}$, be less than or equal to an established maximum allowable multiplication factor based on benchmark calculations and uncertainty terms, i.e.,

$$
k_{s}+\Delta k_{s} \leq 1-\Delta k_{c}-\Delta k_{m}
$$


B-13

Table B.9. Total dose estimated for various casks configurations

\begin{tabular}{lcc}
\hline \multicolumn{1}{c}{ Cask model } & $\begin{array}{c}\text { Dose at 0 } \\
(\mathbf{m r e m} / \mathbf{h})\end{array}$ & $\begin{array}{c}\text { Dose at 30.96 } \\
(\mathbf{m r e m} / \mathbf{h})\end{array}$ \\
\hline 21-element cask, no backfill, nominal shield design & 7.3 & 6.3 \\
21-element cask, DUS backfill, nominal shield design & 1.9 & 2.0 \\
21-element cask, DUS backfill, no radial lead shield & 3.3 & 3.6 \\
21-element cask, DUS backfill, no radial lead shield, & & 6.5 \\
85\% of nominal DU shield & 5.6 & \\
21-element cask, DUS backfill, no radial lead shield, & & 8.1 \\
\hline 75\% of nominal DU shield & 7.7 & \\
\hline
\end{tabular}

where

$\Delta k_{s}=$ uncertainty in the value of $k_{s}$

$\Delta k_{c}=$ sum of biases and uncertainties in the calculation of $k_{c}$ and

$\Delta k_{m}=$ additional margin to ensure subcriticality.

Typically, $\Delta k_{m}$ is assigned an administrative limit of 0.05 . In Monte Carlo calculations, $\Delta k_{s}$ is the uncertainty in the calculated value of $k_{e f f}$, for KENO V.a calculations, uncertainty is specified at a $67 \%$, or $1 \sigma$, confidence level. Multipliers of 2 or 3 on $\sigma$ will increase the confidence on the range of $k_{e f f}$ to $95 \%$ or $99 \%$, respectively. The value $\Delta k_{c}$ is obtained from a validation of the code system and the cross-section library. Although little validation work has been completed for SCALE 4.3 with the 238-group library, the value of $\Delta k_{c}$ is expected to be much less than 0.01 , based on validation work performed using SCALE 4.2 for LWR-type fresh fuel experiments. Thus, it may be concluded that with a high degree of confidence, subcriticality is ensured for $k_{\text {eff }}+3 \sigma \leq 0.94$.

Under this approach, the results given in Tables B.4 and B.5 indicate that a system loaded with fresh fuel would have a large margin of subcriticality under dry conditions both with and without DUS backfill within the MPC conceptual design. Furthermore, under flooded conditions, while the nominal cask design substantially exceeds subcriticality limits, a sand-filled cask has an additional margin of $>15 \%$ for the more reactive $5.0 \mathrm{wt} \%$ fresh fuel. Note that in all cases, a fresh fuel loading was assumed. An additional margin 
resulting from the negative reactivity of activation products and fission products in spent fuel would be observed if credit is taken for burnup. Finally, other candidate DUS compositions may contain significant fractions of boron. Because boron is a strong thermal neutron poison, it would introduce additional margin for subcriticality in thermal systems.

The higher average energy for fission seen under air-filled and sand-filled (both wet and dry) conditions indicate a spectral shift into resonance-dominated domains. Such conditions would require the resonanceenergy resolution of a fine-structure cross-section library such as the 238-group library used in this work. Scoping analyses performed with a 44-group library developed for the criticality analysis of LWR fuel showed $>1 \%$ error in the prediction of $k_{\text {eff }}$ relative to 238-group results for air, sand/air, and sand/water configurations, but close agreement for the water-only configuration. Because the value of $k_{\text {eff }}$ in a dry cask is substantially below the limit for subcriticality, such a small error term is unimportant. However, although the sand-filled configuration possesses ample excess margin for subcriticality even under flooded conditions, this will not necessarily be the case for other cask designs or other sand compositions. Thus, it is recommended that fine-energy-structure libraries be used in any future DUS studies. Note, however, that few benchmark experiments exist for spectra as seen in the water and sand filled cask. These benchmarks would be necessary to validate any criticality code for analysis in this domain.

\section{B.6.2 Shielding Analysis}

Based on the results shown in Tables B.6 through B.8, it is clear that the addition of DUS in the MPC cask design results in a significant reduction in dose rates. Neutron doses are reduced by about $50 \%$; primary gamma-ray doses are reduced by about 20 to $25 \%$ of nominal doses, and secondary gamma-ray dose rates are more than halved. Note that gamma rays are produced primarily by neutron absorption in the outer neutron shield; thus, a similar reduction is expected in both neutron and secondary gamma-ray dose rates.

Furthermore, both dose rates could be significantly reduced by the addition of boron in the DUS composition. Estimated total doses given in Table B.9 show a reduction in dose of $65 \%$ to $75 \%$ by the addition of a DUS filler.

Calculations in which heavier components of the MPC transportation overpack shield design were removed showed that these components have the most significant effect on primary gamma rays. Neutron, and therefore secondary gamma-ray, dose rates are relatively unaffected by the removal of the shielding material. This phenomenon is as would be expected because these dense materials are intended primarily as gamma-ray shields and act primarily as scattering media for neutrons. However, because the largest component of the total dose comes from primary gamma rays, the total dose is sensitive to the presence of the 


\section{B-15}

heavy materials. The shielding calculations indicate that the $1.27-\mathrm{cm}(0.5-\mathrm{in}$.) lead shield can be completely removed from the MPC design, together with roughly $15 \%$ of the $3.81-\mathrm{cm}$ (1.5-in.) DU shield, while maintaining a dose comparable to that of the air-filled cask. It is interesting to note that the maximum dose is obtained at a $0^{\circ}$ angle for an air-filled cask, but that the maximum dose appears to occur at a $30.96^{\circ}$ angle for a sand-filled cask.

Table B.10 gives the masses of the various shield components for the nominal MPC transportation cask design. Table B.11 provides the reduced masses resulting from the removal of the lead shield and a $15 \%$ reduction in the radius of the DU shield. All radii beyond the DU shield were adjusted accordingly. These tables indicate that such a shielding modification would result in a total mass reduction of $7,016 \mathrm{~kg}$. The total volume of mixture of sand and air in a backfilled MPC cask is $\sim 1.06 \times 10^{6} \mathrm{~cm}^{3}$. For an effective density of $2.66 \mathrm{~g} / \mathrm{cm}^{3}$, this represents a total added mass of $13,100 \mathrm{~kg}$ of DUS. Thus, an MPC cask with DUS backfill would have an increased mass of roughly $6,100 \mathrm{~kg}$ even with a modified shield design.

Table B.10. Nominal MPC shield component masses

\begin{tabular}{|c|c|c|c|c|c|}
\hline Material & Density & $\mathbf{r}_{\text {inner }}$ & $\mathbf{r}_{\text {outer }}$ & Volume & Mass \\
\hline SS-316 & 7.75 & 77.47 & 81.28 & 929,080 & 7,200 \\
\hline DU & 19.05 & 81.28 & 85.09 & 973,676 & 18,549 \\
\hline $\mathrm{Pb}$ & 11.344 & 85.09 & 86.36 & 334,469 & 3,794 \\
\hline SS-316 & 7.75 & 86.36 & 92.71 & $1,746,670$ & 13,537 \\
\hline Neutron shield & 0.91 & 92.71 & 107.95 & $4,697,428$ & 4,275 \\
\hline SS-304 & 7.92 & 107.95 & 108.59 & 211,211 & 1,673 \\
\hline Total & & & & & 49,027 \\
\hline
\end{tabular}


B-16

Table B.11. Modified MPC shield component masses

\begin{tabular}{|c|c|c|c|c|c|}
\hline Material & Density & $\mathbf{r}_{\text {inner }}$ & $\mathbf{r}_{\text {outer }}$ & Volume & Mass \\
\hline SS-316 & 7.75 & 77.47 & 81.28 & 929,080 & 7,200 \\
\hline DU & 19.05 & 81.28 & 84.52 & 824,781 & 15,712 \\
\hline $\mathrm{Pb}$ & 11.344 & 84.52 & 84.52 & 0 & 0 \\
\hline SS-316 & 7.75 & 84.52 & 90.87 & $1,710,746$ & 13,258 \\
\hline Neutron shield & 0.91 & 90.87 & 106.11 & $4,611,209$ & 4,196 \\
\hline SS-304 & 7.92 & 106.11 & 106.74 & 207,618 & 1,644 \\
\hline Total & & & & & 42,011 \\
\hline
\end{tabular}

Clearly, it is not possible to offset the mass of DUS in a fully loaded MPC by corresponding reductions in shielding masses. The design thicknesses of stainless steel components are most likely required to meet structural requirements; hence, no attempts were made to assess the shielding worth of such components. If the increased mass of the filled system exceeds design constraints, it may be necessary to redesign the cask. However, other options are available. Removal of the DU plug added to the lid of the MPC inner shell would reduce the MPC mass by about $1600 \mathrm{~kg}$. Replacement of DUS with a lighter material in the top $50 \mathrm{~cm}$ of the inner shell with a lighter material would save $>2000 \mathrm{~kg}$; this region of the MPC does not contain fuel and thus does not necessarily require a DUS backfill. However, the effect of such modifications has not been evaluated from a shielding (or criticality) perspective.

\section{B.7 REFERENCES}

American National Standard Institute, 1984. American National Standard for Nuclear Criticality Safety Criteria for the Handling, Storage, and Transportation of LWR Fuel Outside Reactors, ANSU/ANS-8.17, American Nuclear Society, La Grange Park, Illinois, (Reaffirmed August 1989).

Greene, N. M., April 1995. "BONAMI: Resonance Self-Shielding by the Bondarenko Method," Sect. F1 of SCALE: A Modular Code System for Performing Standardized Computer Analyses for Licensing Evaluation, NUREG/CR-0200, Rev. 4, ORNL/NUREG/CSD-2/R4, Vols. I, II, and III, Martin Marietta Energy Systems, Inc., Oak Ridge National Laboratory, Oak Ridge, Tennessee. (Available from Radiation Shielding Information Center, ORNL, as CCC-545.) 
Greene, N. M., Ford III, W. E., Petrie, L. M., and Arwood, J. W., October 1992. AMPX-77: AModular Code System for Generating Coupled Multigroup Neutron-Gamma Cross-Section Libraries from ENDF/B-IV and/or ENDF/B-V, ORNL/CSD/TM-283, Martin Marietta Energy Systems, Inc., Oak Ridge National Laboratory, Oak Ridge, Tennessee.

Greene, N. M. and Petrie, L. M., April 1995. "XSDRNPM: A One-Dimensional Discrete-Ordinates Code for Transport Analysis," Sect. F3 of SCALE: A Modular Code System for Performing Standardized Computer Analyses for Licensing Evaluation, NUREG/CR-0200, Rev. 4, ORNL/NUREG/CSD-2/R4, Vols. I, II, and III, Martin Marietta Energy Systems, Inc., Oak Ridge National Laboratory, Oak Ridge, Tennessee. (Available from Radiation Shielding Information Center, ORNL, as CCC-545.)

Greene, N. M., Petrie, L. M., and Westfall, R. M., April 1995. 'NITAWL-II: SCALE System Module for Performing Resonance Shielding and Working Library Production," Sect. F2 of SCALE: A Modular Code System for Performing Standardized Computer Analyses for Licensing Evaluation, NUREG/CR-0200, Rev. 4, ORNL/NUREG/CSD-2/R4, Vols. I, I, and III, Martin Marietta Energy Systems, Inc., Oak Ridge National Laboratory, Oak Ridge, Tennessee. (Available from Radiation Shielding Information Center, ORNL, as CCC-545.)

Hermann, O. W. and Westfall, R. M., April 1995. “ORIGEN-S: SCALE System Module to Calculate Fuel Depletion, Actinide Transmutation, Fission Product Buildup and Decay, and Associated Radiation Source Terms," Sect. F7 of SCALE: A Modular Code System for Performing Standardized Computer Analyses for Licensing Evaluation, NUREG/CR-0200, Rev. 4, ORNL/NUREG/CSD-2/R4, Vols. I, II, and III, Martin Marietta Energy Systems, Inc., Oak Ridge National Laboratory, Oak Ridge, Tennessee. (Available from Radiation Shielding Information Center, ORNL, as CCC-545.)

Hermann, O. W. and Parks, C. V., April 1995. "SAS2H: A Coupled One-Dimensional Depletion and Shielding Analysis Module," Sect. S2 of SCALE: A Modular Code System for Performing Standardized Computer Analyses for Licensing Evaluation, NUREG/CR-0200, Rev. 4, ORNL/NUREG/CSD-2/R4, Vols. I, II, and III, Martin Marietta Energy Systems, Inc., Oak Ridge National Laboratory, Oak Ridge, Tennessee. (Available from Radiation Shielding Information Center, ORNL, as CCC-545.)

Landers, N. F. and Petrie, L. M., April 1995. "CSAS: An Enhanced Criticality Safety Analysis Module With Search Options," Sect. C4 of SCALE: A Modular Code System for Performing Standardized Computer Analyses for Licensing Evaluation, NUREG/CR-0200, Rev. 4, ORNL/NUREG/CSD-2/R4, Vols. I, II, and III, Martin Marietta Energy Systems, Inc., Oak Ridge National Laboratory, Oak Ridge, Tennessee. (Available from Radiation Shielding Information Center, ORNL, as CCC-545.)

Landers, N. F., Petrie, L. M., and Bucholz, J. A., April 1995. "The Material Information Processor for SCALE," Sect. M7 of SCALE: A Modular Code System for Performing Standardized Computer Analyses for Licensing Evaluation, NUREG/CR-0200, Rev. 4, ORNL/NUREG/CSD-2/R4, Vols. I, II, and III, Martin Marietta Energy Systems, Inc., Oak Ridge National Laboratory, Oak Ridge, Tennessee. (Available from Radiation Shielding Information Center, ORNL, as CCC-545.)

Petrie, L. M. and Landers, N. F., April 1995. "KENO V.a: An Improved Monte Carlo Criticality Program with Supergrouping," Sect F11 of SCALE: A Modular Code System for Performing Standardized Computer Analyses for Licensing Evaluation, NUREG/CR-0200, Rev. 4, ORNL/NUREG/CSD-2/R4, Vols. I, II, and III, Martin Marietta Energy Systems, Inc., Oak Ridge National Laboratory, Oak Ridge, Tennessee. (Available from Radiation Shielding Information Center, ORNL, as CCC-545.) 
Tang, J. S., April 1995. "SAS4: A Monte Carlo Cask Shielding Analysis Module Using an Automated Biasing Procedure," Sect. S4 of SCALE: A Modular Code System for Performing Standardized Computer Analyses for Licensing Evaluation, NUREG/CR-0200, Rev. 4, ORNL/NUREG/CSD-2/R4, Vols. I, II, and III, Martin Marietta Energy Systems, Inc., Oak Ridge National Laboratory, Oak Ridge, Tennessee. (Available from Radiation Shielding Information Center, ORNL, as CCC-545.)

U.S. Department of Energy, 1994. MultiPurpose Canister System Evaluation, DOE/RW-0445, Washington, D.C.

U.S. Nuclear Regulatory Commission, April 1995. SCALE: AModular Code System for Performing Standardized Computer Analyses for Licensing Evaluation, NUREG/CR-0200, Rev. 4, ORNL/NUREG/CSD-2/R4, Vols. I, II, and III, Martin Marietta Energy Systems, Inc., Oak Ridge National Laboratory, Oak Ridge, Tennessee. (Available from Radiation Shielding Information Center, ORNL, as CCC-545.)

West, J. T., Hoffman, T. J., and Emmett, M. B., April 1995. MORSE-SGC for the SCALE System, Sect. F9 of SCALE: A Modular Code System for Performing Standardized Computer Analyses for Licensing Evaluation, NUREG/CR-0200, Rev. 4, ORNL/NUREG/CSD-2/R4, Vols. I, II, and III, Martin Marietta Energy Systems, Inc., Oak Ridge National Laboratory, Oak Ridge, Tennessee. (Available from Radiation Shielding Information Center, ORNL, as CCC-545.) 
Appendix C:

THERMAL ANALYSES OF DUSCOBS 


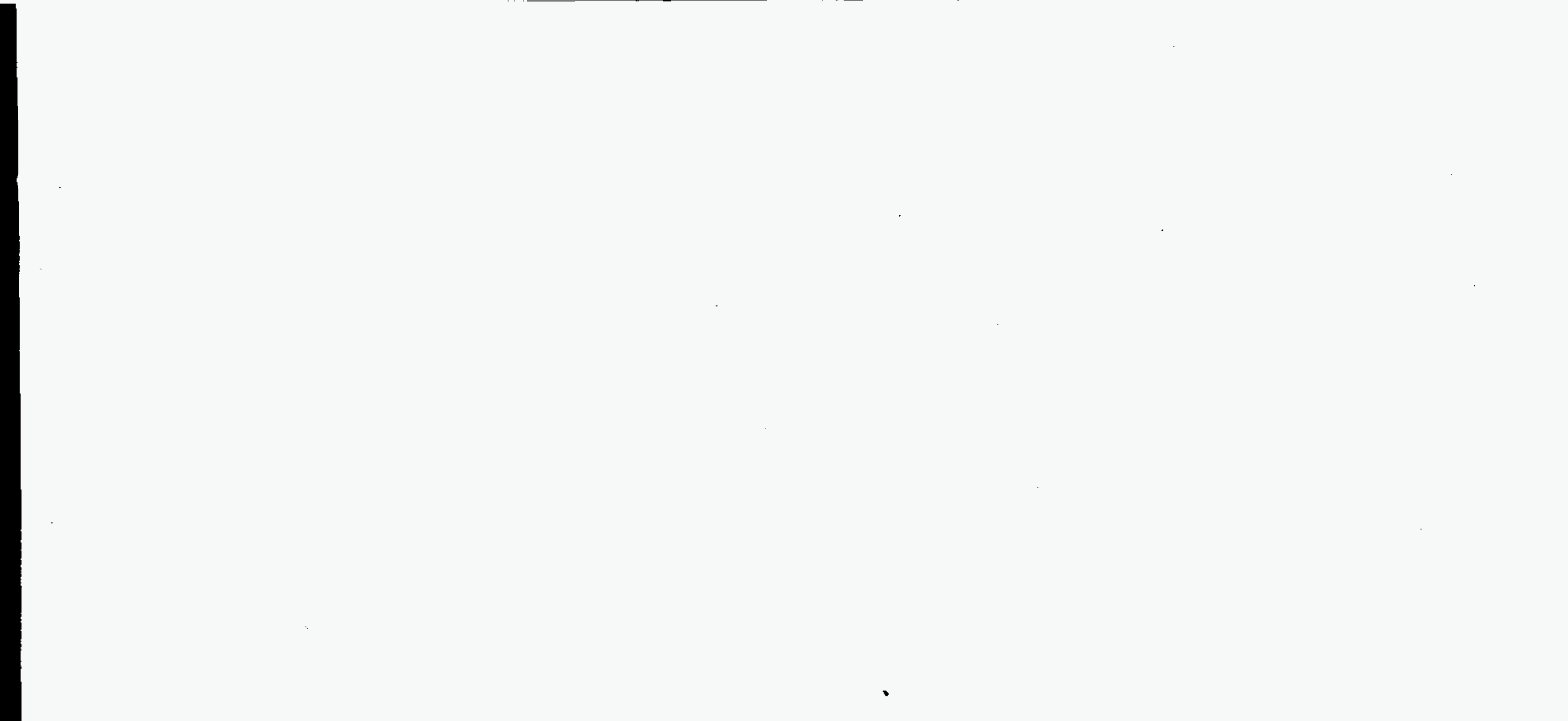




\section{APPENDIX C: THERMAL ANALYSES OF DUSCOBS}

\section{C.1 INTRODUCTION}

The MPC-designed thermal limit for both storage and transportation is assumed to be a fuel-rod-cladding temperature of $340^{\circ} \mathrm{C}$. Previous analyses (DOE, September 1994) have shown that this limit is not exceeded in the current MPC design. However, the addition of DUS glass beads significantly alters the heat-transfer mechanisms within the MPC and, consequently, the temperature distribution. Addition of the glass beads essentially eliminates two of the mechanisms for transferring heat from the fuel rods to the MPC shell (natural convection and thermal radiation), but the addition of the beads enhances a third mechanism (conduction) even though glass beads are relatively poor conductors. Consequently, new calculations are needed to quantify the thermal performance of the glass-bead-filled MPC. A series of heat-transfer models was developed to make a preliminary determination of the feasibility of a glass-bead-filled MPC. The models start out very conservatively (i.e., are known to overpredict the maximum cladding temperature) and progressively are made less conservative and more detailed, as needed.

\section{C.2 ANALYSIS}

A large 21 PWR MPC inside a large transportation cask was examined because this configuration is expected to yield the maximum cladding temperature. The modeling was accomplished using the generalpurpose, heat-conduction code HEATING (Childs, 1993). The initial model is an axisymmetric ( $R-Z$ ) model of the MPC in a transport cask. This model has a fairly detailed representation of both the MPC and the shipping cask. However, the internal details of the MPC are not modeled (i.e., neither the basket assembly nor the fuel rod bundles are included in the model). The entire internal volume of the MPC is assumed to be filled with silicate glass beads. This assumption is conservative because both the aluminum/boron matrix and stainless steel used in the basket structure have much higher conductivities than do the glass beads. The conductivities of the Zircaloy fuel-rod-cladding material and the fuel itself are also higher than those of the glass beads. The glass beads are assumed to have the same thermal conductivity as dry sand $-0.33 \mathrm{~W} / \mathrm{m}-\mathrm{K}$ (0.19 Btw/h-ft- ${ }^{\circ}$ F).

Heat generation is modeled in a cylindrical subvolume of the glass beads. This volume roughly encompasses the fuel-containing portion of the fuel rods and has a diameter of $63.5 \mathrm{~cm}$ (25 in.) and a height of $365.8 \mathrm{~cm}$ ( $144 \mathrm{in}$.). The nominal volumetric heat-generation rate is determined by dividing the total heat load $(14.73 \mathrm{~kW}$ or $50,250 \mathrm{Btu} / \mathrm{h})$ by the volume of this cylindrical region. There is an axial variation in the volumetric heat generation given in Table C.1. 


$$
\text { C-4 }
$$

Table C.1. Axial variation in power along a fuel rod

\begin{tabular}{cc}
\hline $\begin{array}{c}\text { Position } \\
\text { (Fractional distance from } \\
\text { bottom of fuel) }\end{array}$ & Normalized power \\
\hline 0.025 & 0.624 \\
0.075 & 0.896 \\
0.125 & 1.010 \\
0.175 & 1.044 \\
0.225 & 1.077 \\
0.275 & 1.080 \\
0.325 & 1.080 \\
0.375 & 1.079 \\
0.425 & 1.079 \\
0.475 & 1.078 \\
0.525 & 1.078 \\
0.575 & 1.078 \\
0.625 & 1.078 \\
0.675 & 1.077 \\
0.725 & 1.075 \\
0.775 & 1.070 \\
0.825 & 1.040 \\
0.875 & 0.986 \\
0.925 & 0.863 \\
0.975 & 0.613 \\
\hline
\end{tabular}




\section{C-5}

Heat transfer across the gap between the MPC and the transport cask is modeled as conduction through still air and thermal radiation. Both surfaces are assumed to have emissivities of 0.5 . The external surface boundary conditions on the sides and top of the shipping cask are the result of natural convection and radiant heat transfer to an ambient air temperature of $37.8^{\circ} \mathrm{C}\left(100^{\circ} \mathrm{F}\right)$ and a solar heat load of $387.5 \mathrm{~W} / \mathrm{m}^{2}$ $(122.92 \mathrm{Btu} / \mathrm{h}-\mathrm{f})$. The bottom of the cask is assumed to be adiabatic.

This model produces a maximum temperature of $1580^{\circ} \mathrm{C}\left(2876^{\circ} \mathrm{F}\right)$ in the glass beads. It is clear that this model is much too conservative and that a more detailed representation of the MPC internals is needed. Thus, a second model was developed that includes the aluminum/boron matrix and stainless steel basket structure. This is a two-dimensional model of a horizontal cut through the MPC. Because of its symmetry, only one-fourth of the cross section is modeled. (Actually, if full advantage were taken of symmetry, only one-eighth of the cross section would need to be modeled, but it is simpler to set up the model for onequarter.) This model extends in the radial direction only to the inner surface of the MPC shell. The extent of the model is shown in Fig. C.1. (Note that dimensions on the axes are in inches.) The fuel rods are still not included in the model. All of the volume in the model not occupied by the basket structure is filled with glass beads. A volumetric heat generation is modeled in the square cavities in the basket that hold the fuel-rod bundles. The heat generation rate used is $8 \%$ over a nominal value calculated as the rod-bundle heat load divided by the cross-sectional area of the square cavity and the overall length of the fuel region. The conductivity for stainless steel and aluminum are assumed to be $17.3 \mathrm{~W} / \mathrm{m}-\mathrm{K}\left(10 \mathrm{Btu} / \mathrm{h}-\mathrm{ft}-{ }^{\circ} \mathrm{F}\right)$ and $173 \mathrm{w} / \mathrm{m}-\mathrm{K}\left(100 \mathrm{Btu} / \mathrm{h}-\mathrm{ft}-{ }^{\circ} \mathrm{F}\right)$, respectively.

Contour plots of the computed temperature rise above the shell temperature are presented in Fig. C.2. Parts (a), (b), and (c) of this figure give the temperature rise for cases with 21,20 , and 16 fuel rod bundles, respectively. The maximum temperature in the MPC shell obtained from the first model is $219^{\circ} \mathrm{C}\left(427^{\circ} \mathrm{F}\right)$. Therefore, to avoid exceeding the temperature limit of $340^{\circ} \mathrm{C}$, the maximum temperature rise above the MPC shell temperature cannot be more than $121^{\circ} \mathrm{C}\left(219^{\circ} \mathrm{F}\right)$. The 21-rod-bundle and 20-rod-bundle examples exceed the temperature limit, but the 16-rod-bundle case does not.

The second model is still overly conservative because it assumes that all heat generated within the fuel rods is conducted exclusively through the low-conductivity glass beads to reach the basket. In reality, the heat is conducted through a combination of glass beads, Zircaloy cladding, and fuel. To account for this, an effective conductivity for this combination of materials is derived using the finite-element, heat-conduction code TOPAZ2D (Shapiro, 1986). The finite element model is shown in Fig. C.3. This small portion of the fuel-rod bundle is representative of the entire bundle-by repeating this portion, the entire bundle can be constructed. Different constant temperatures are applied to the left and right surfaces of this model, and a 


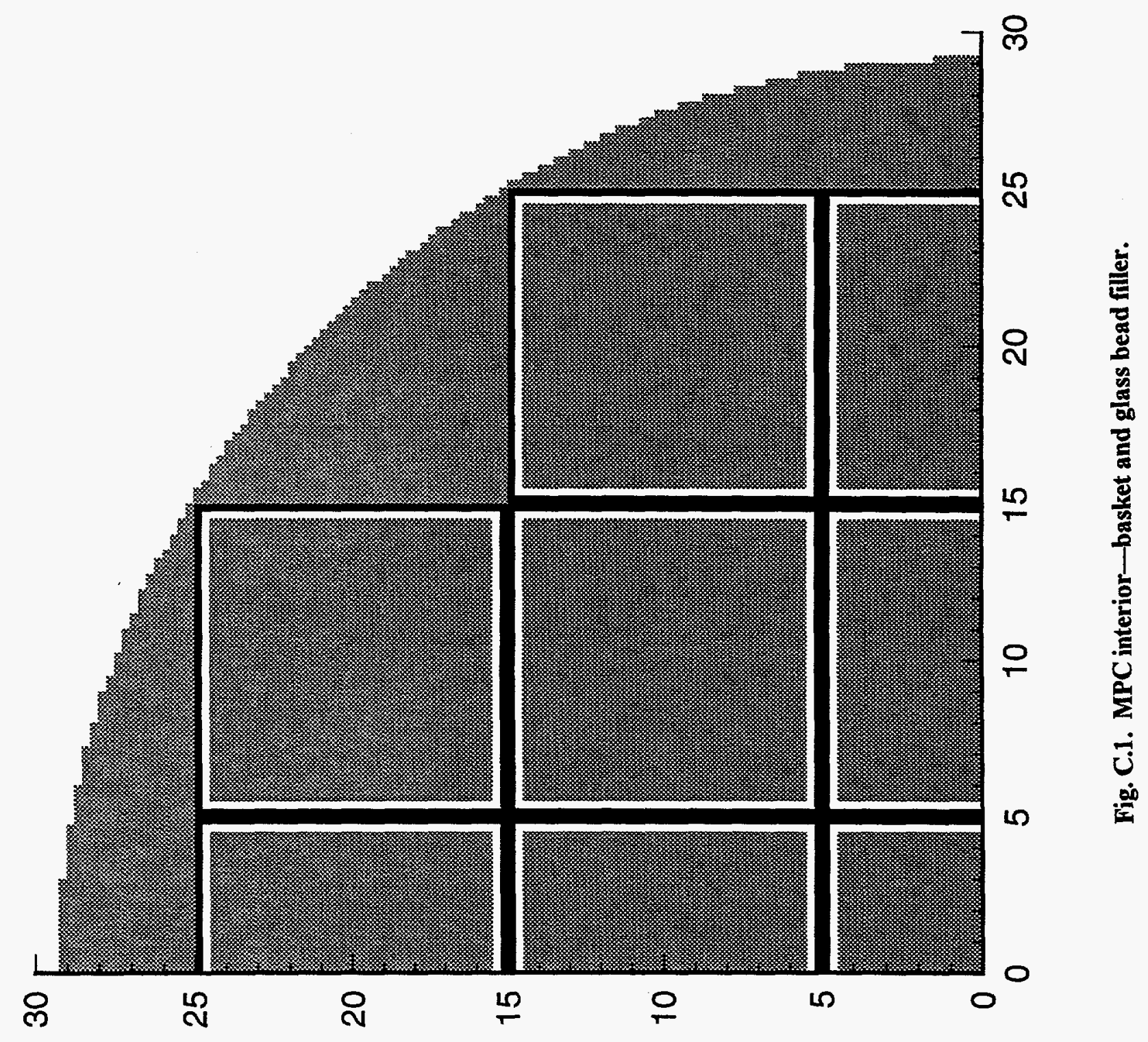




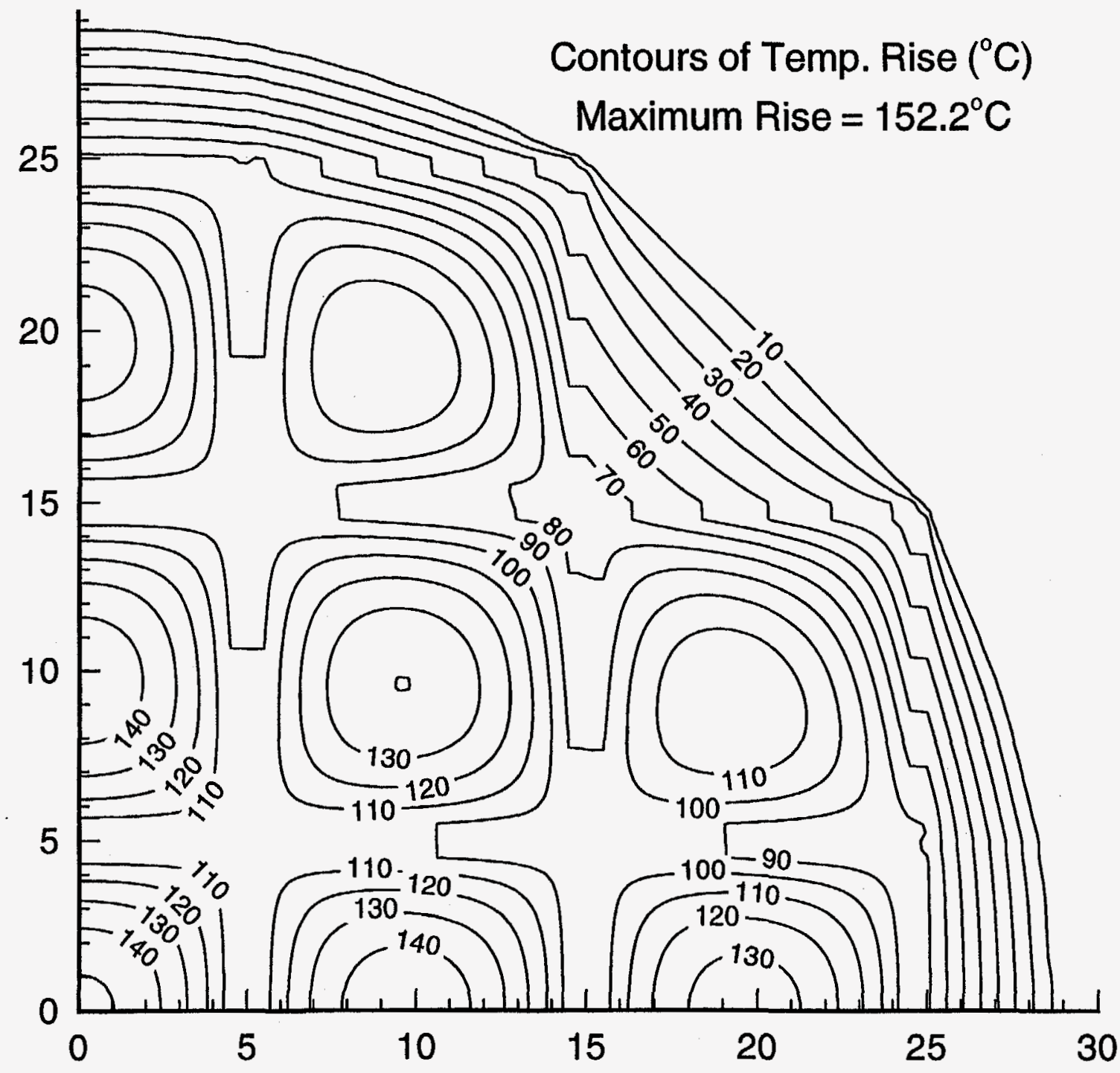

Fig. C.2a. Temperature distribution in MPC (fuel rods not included in model). 


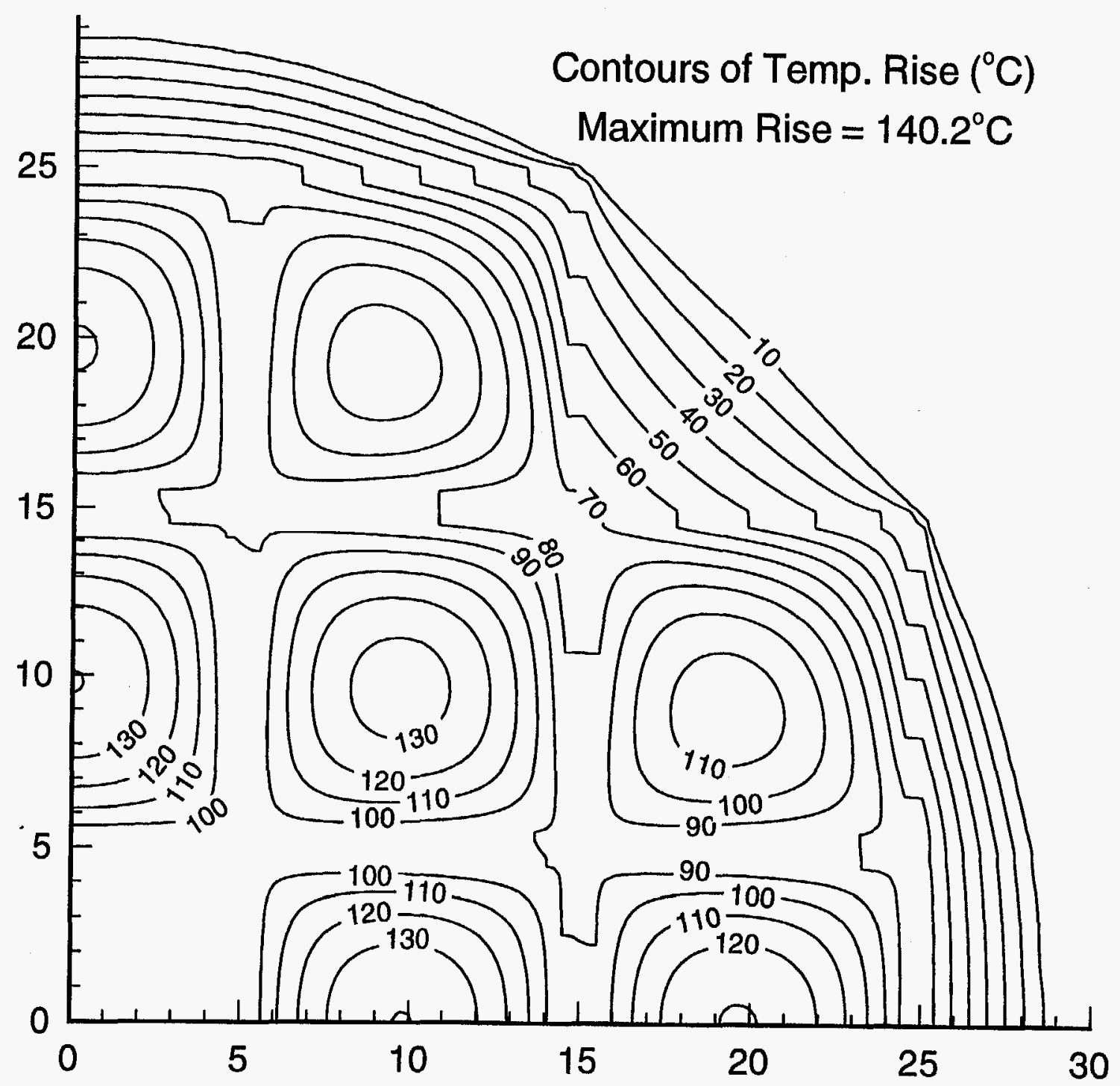

Fig. C.2b. Temperature distribution in MPC (fuel rods not included in model), 20 rod bundles. 


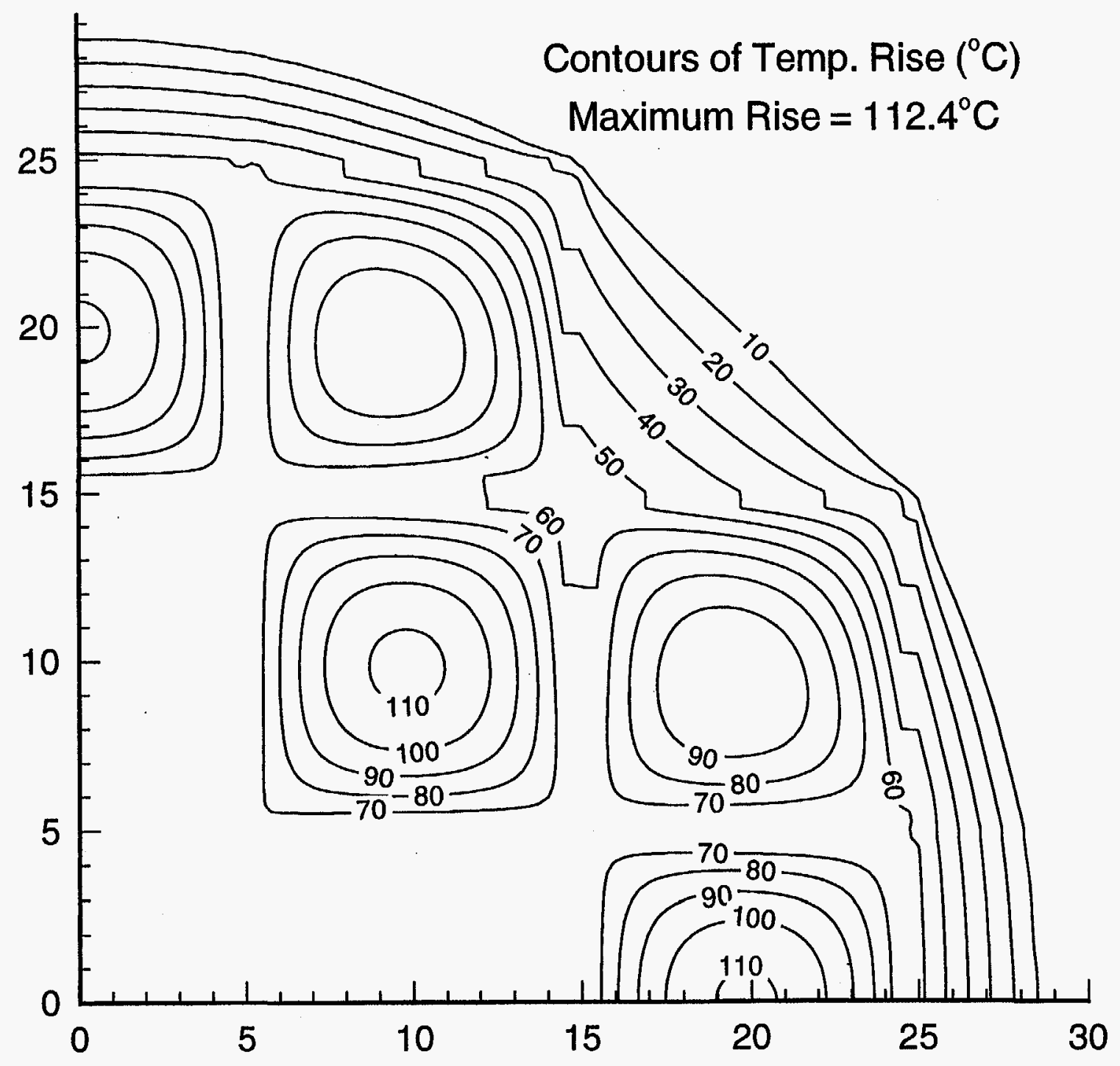

Fig. C.2c. Temperature distribution in MPC (fuel rods not included in model), 16 rod bundles. 


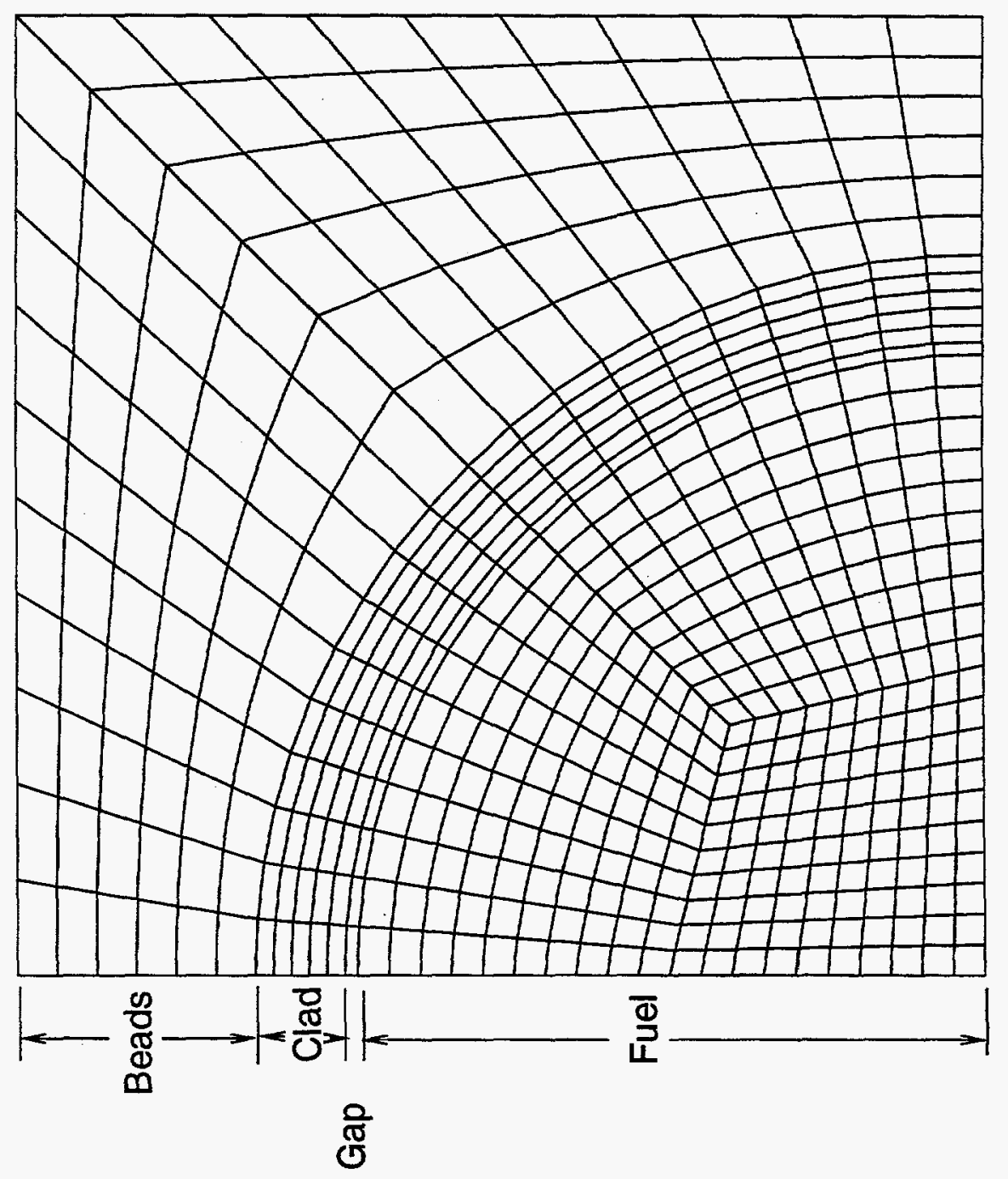

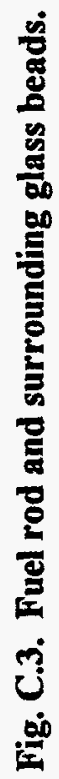




\section{C-11}

total heat flow through the model is calculated. From the results of this model, the effective conductivity was determined to be $0.69 \mathrm{~W} / \mathrm{m}-\mathrm{K}\left(0.40 \mathrm{Btu} / \mathrm{h}-\mathrm{ft}-{ }^{\circ} \mathrm{F}\right)$. When the effective glass-beads/fuel-rod conductivity is used, the temperature rise in the 21-rod-bundle example, respectively does not exceed design limitation. The temperature rise contour plots for the 21-rod-bundle case and the 20-rod-bundle case are presented in Figs. C.4 (a) and (b).

The conductivity of the uranium-loaded silicate glass is expected to be higher than the value used in these analyses which will result in a lower maximum temperature than indicated by these calculations.

\section{C.2 CONCLUSION}

The conclusion of this study is that a silicate-glass-bead-filled MPC is feasible from the standpoint of thermal performance.

\section{C.3 REFERENCES}

Childs, K. W., February 1993. HEATING 7.2 User's Manual, ORNL/TM-12262, Oak Ridge National Laboratory, Martin Marietta Energy Systems, Inc., Oak Ridge, Tennessee.

U.S. Department of Energy, September 1994. Multi-Purpose Canister System Evaluation-A Systems Engineering Approach, Washington, D.C.

Shapiro, A. B., July 1986. TOPAZ2D—A Two-Dimensional Finite Element Code for Heat Transfer Analysis, Electrostatic, and Magnetostatic Problems, UCID-20824, Lawrence Livermore National Laboratory, Livermore, California. 


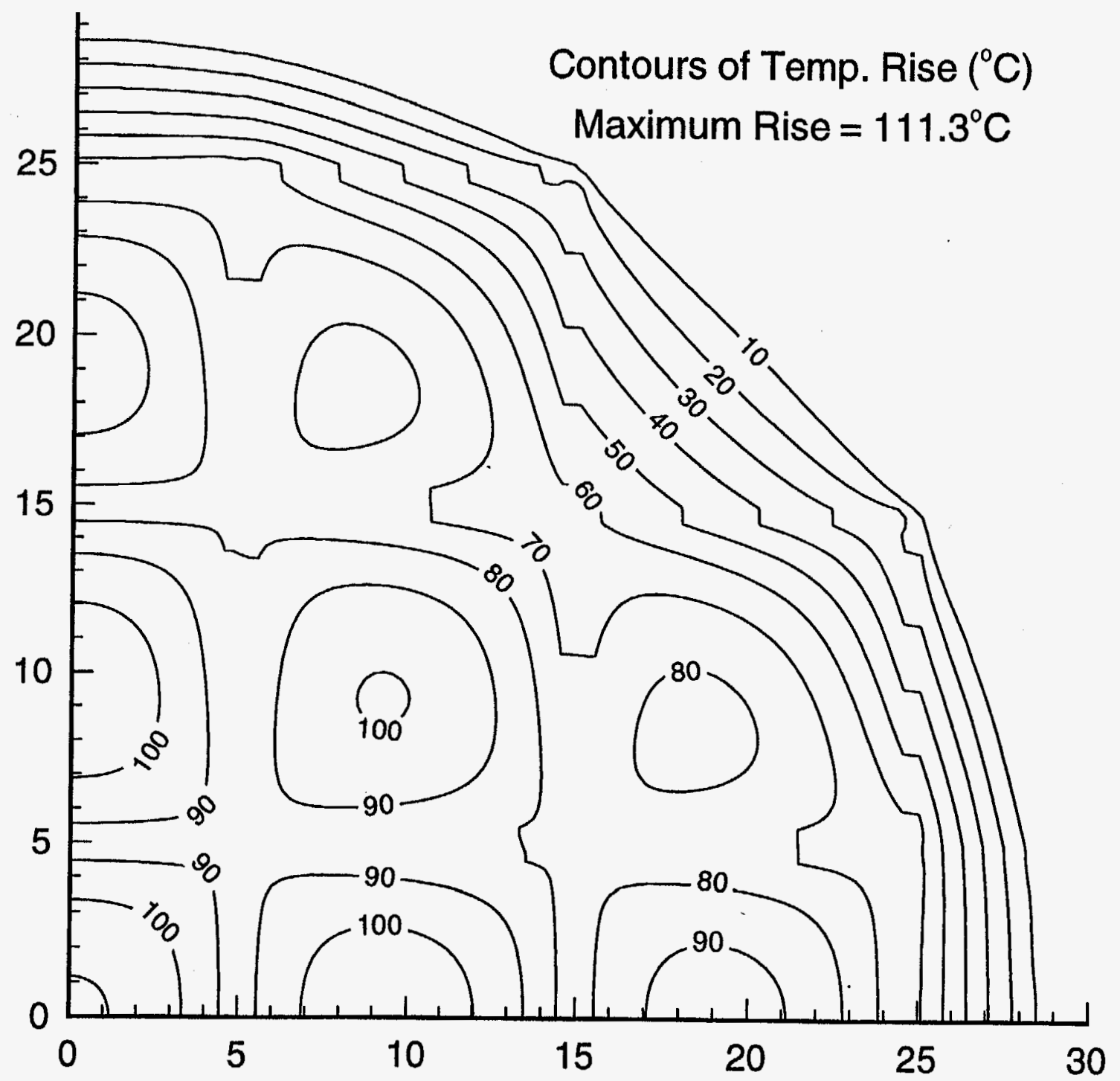

Fig. C.4a. Temperature distribution in MPC (glass-bead conductivity modified to account for fuel rods), 21 rod bundles. 


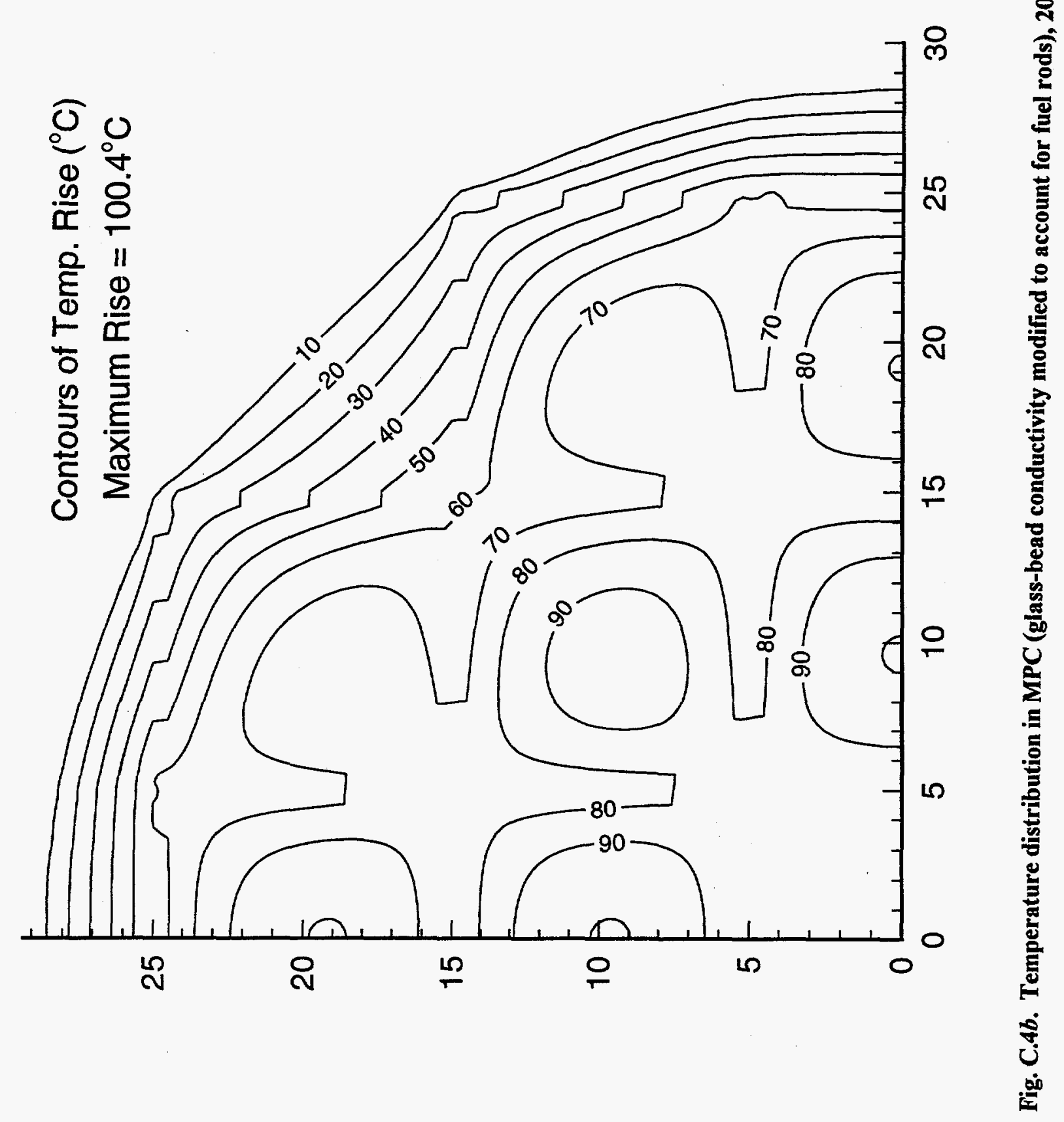


Appendix D:

FINAL ENRICHMENT DISTRIBUTION OF LWR SNF 


\section{APPENDIX D: FINAL ENRICHMENT DISTRIBUTION OF LWR SNF}

\section{D.1 BACKGROUND}

Those conducting waste management studies to reduce the potential for a nuclear criticality accident in a future geological repository must examine the quantities and distribution of fissile isotopes that are present in discharged boiling-water reactor (BWR) and PWR SNF scheduled for disposition. The major fissile isotopes present in LWR fuels that impact criticality safety are the nuclides; ${ }^{235} \mathrm{U},{ }^{239} \mathrm{Pu}$, and ${ }^{241} \mathrm{Pu}$. The sum of the quantities of these three nuclides, expressed as a percentage of the total amount of all $U$ and $P u$ isotopes present in a batch of discharged fuel, determines the final enrichment of the fuel batch under consideration. The final enrichment provides an approximate measure of the nuclear criticality potential. As the final enrichment increases, the mass, geometry, or administrative controls that must be in place to prevent nuclear criticality become more stringent. Below an enrichment of about $0.7 \%$, however, criticality is no longer a concern because the infinite multiplication factor for any heterogeneous or homogeneous mixture of fuel and water, even under conditions of optimum moderation, is less than unity. The current study examines the distribution of the final enrichment of the LWR SNF which was discharged through December 31, 1993, and which currently resides in the fuel storage pools of the various utilities or in one of several AFR facilities.

\section{D.2 ASSUMPTIONS}

The information on which this study is based is the SNF data contained in Nuclear Fuel Data Form RW-859 (DOE, December 31, 1993). Historical inventories of discharged LWR SNF recorded on this data tape have been updated through December 31, 1993. The total inventory of BWR fuel discharged from U.S. commercial reactors through December 31,1993 , amounts to $10,178.53$ metric tons of initial heavy metal (MTIHM), while that for discharged PWR fuel amounts to 17,851.69 MTIHM. The data include the quantity (MTIHM) of fuel contained in each discharge batch, the initial enrichment of the batch, and the final burnup at discharge for each batch (expressed in MWd/MTIHM).

\section{D.3 METHODOLOGY}

The methodology used to determine the distribution of the final enrichment of the historical inventory of discharged LWR SNF began with the creation of a 3-D array whose members represent the quantities of discharged LWR fuel contained in the various discharged batches, categorized by (a) fuel type, (b) initial enrichment, and (c) burnup. The range of initial enrichment (0-5\%) was divided into 50 equal increments of $0.1 \%$ each; the range of fuel burnup (0-60,000 MWd/MTIHM) was divided into 24 equal increments of 2,500 MWd/MTIHM each. Initial enrichment and burnup values at the midpoint of each increment were assigned to each of the array members to determine the final enrichment at discharge. 
Next, the ORGENTRE (Oak Ridge Waste GENeration and TREatment) code, a series of computer codes and data bases which characterize nuclear waste generation and treatment, was run to calculate the nuclide composition for BWR and PWR fuel corresponding to each combination of initial enrichment and final burnup increment midpoint values. The ORGENTRE code (Morrison, 1986) is based on the ORIGEN2 isotope generation and decay code (Croff, 1980), which is used worldwide for simulating the nuclear fuel cycle. The final fuel enrichment associated with each member of the 3-D array was obtained by summing the

weights of the nuclides, ${ }^{235} \mathrm{U},{ }^{239} \mathrm{Pu}$, and ${ }^{241} \mathrm{Pu}-$ calculated by ORGENTRE and corresponding to a 1-MTIHM fuel batch-and expressing this quantity as a percentage of the total mass of all $U$ and $\mathrm{Pu}$ isotopes contained in a 1-MTIHM fuel batch at discharge.

Because the range of the libraries contained within ORGENTRE is limited to BWR fuel having an initial enrichment in the range of 1 to $4 \%$ and to PWR fuel having an initial enrichment in the range of 2.5 to $5.0 \%$, it was not possible to determine the final fuel enrichment for discharged BWR and PWR fuel batches of which initial enrichments were $<1.0 \%$ and $2.5 \%$, respectively. Consequently, fuel batches corresponding to these low enrichments (3.32\% of all BWR fuel discharged and $14.70 \%$ of all PWR fuel discharged) were not included in determining the distribution of the final enrichment of LWR SNF reported in this document.

\section{D.4 CONCLUSIONS}

Table D.1 shows the distribution of the final enrichment of LWR SNF that has been discharged through December 31, 1993. The percentage of fuel, grouped according to final enrichment range, is as follows: $0.00<1.00 \%$ enr., $0.10 \% ; 1.00-2.00 \%$ enr., $96.64 \% ; 2.00-<3.00 \%$ enr., $2.97 \% ; 3.00-<4.00 \%$ enr., $0.29 \%$.

\section{D.5 REFERENCES}

Croff, A. G., July 1980. A User's Manual for the ORIGEN2 Computer Code, ORNL/TM-7175, Union Carbide Corporation-Nuclear Division, Oak Ridge National Laboratory, Oak Ridge, Tennessee.

Morrison, G. W., March 1986. ORGENTRE, Oak Ridge Waste Generation and Treatment System: User's Manual, ORNL/CF-85/378, Martin Marietta Energy Systems, Inc., Oak Ridge National Laboratory, Oak Ridge, Tennessee.

U.S. Department of Energy, Energy Information Administration, December 31, 1993. Nuclear Fuel Data Form $R W-859$, Washington, D.C. 
D-5

Table D.1. LWR discharge fuel data ${ }^{a}$

\begin{tabular}{|c|c|}
\hline Final enrichment (\%) & MTIHM \\
\hline $0.00-<0.10$ & 0.00 \\
\hline $0.10-<0.20$ & 0.00 \\
\hline $0.20-<0.30$ & 0.00 \\
\hline $0.30-<0.40$ & 0.00 \\
\hline $0.40-<0.50$ & 0.00 \\
\hline $0.50-<0.60$ & 0.00 \\
\hline $0.60-<0.70$ & 0.00 \\
\hline $0.70-<0.80$ & 0.00 \\
\hline $0.80-<0.90$ & 0.18 \\
\hline $0.90-<1.00$ & 24.75 \\
\hline $1.00-<1.10$ & 185.73 \\
\hline $1.10-<1.20$ & 639.69 \\
\hline $1.20-<1.30$ & 2784.09 \\
\hline $1.30-<1.40$ & 6771.70 \\
\hline $1.40-<1.50$ & 7165.29 \\
\hline $1.50-<1.60$ & 3369.71 \\
\hline $1.60-<1.70$ & 1745.96 \\
\hline $1.70-<1.80$ & 765.31 \\
\hline $1.80-<1.90$ & 423.68 \\
\hline $1.90-<2.00$ & 373.16 \\
\hline $2.00-<2.10$ & 223.63 \\
\hline $2.10-<2.20$ & 189.78 \\
\hline $2.20-<2.30$ & 54.30 \\
\hline $2.30-<2.40$ & 31.17 \\
\hline
\end{tabular}


D-6

\begin{tabular}{cc}
\hline Final enrichment (\%) & MTIHM \\
\hline $2.40-<2.50$ & 103.65 \\
$2.50-<2.60$ & 51.79 \\
$2.60-<2.70$ & 7.68 \\
$2.70-<2.80$ & 49.13 \\
$2.80-<2.90$ & 13.85 \\
$2.90-<3.00$ & 19.22 \\
& \\
$3.00-<3.10$ & 18.75 \\
$3.10-<3.20$ & 8.74 \\
$3.20-<3.30$ & 34.87 \\
$3.30-<3.40$ & 2.57 \\
$3.40-<3.50$ & 1.06 \\
$3.50-<3.60$ & 0.64 \\
$3.60-<3.70$ & 0.00 \\
$3.70-<3.80$ & 0.00 \\
$3.80-<3.90$ & 7.18 \\
$3.90-<4.00$ & 0.00 \\
\hline & \\
& \\
& \\
& \\
&
\end{tabular}

${ }^{a}$ Total BWR $=9,840.20 \mathrm{MTIHM}$, total PWR $=15,227.06 \mathrm{MTIHM}$, and total $\mathrm{LWR}=25,067.26 \mathrm{MTIHM}$. 
Appendix E:

FUTURE WORK 

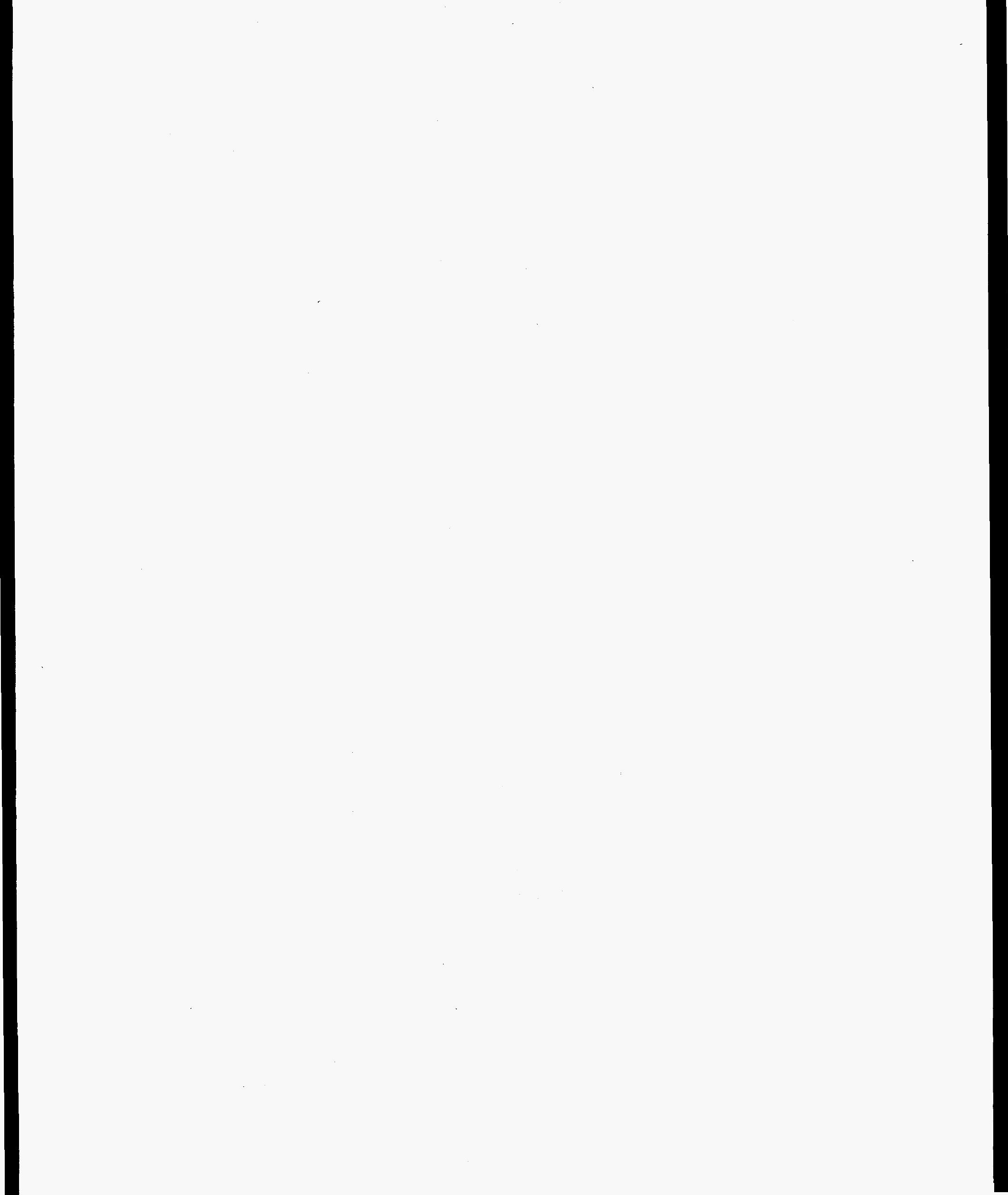


\section{APPENDIX E: FUTURE WORK}

Analysis has identified where added work is needed to understand the benefits and costs of DUSCOBS. These are identified in Table E.1.

Table E.1. DUSCOBS issues

\begin{tabular}{|c|c|}
\hline Issue & Explanation \\
\hline \multicolumn{2}{|l|}{ Baseline assumptions } \\
\hline SNF composition & $\begin{array}{l}\text { Repository criticality issues depend on the quantities and enrichment } \\
\text { levels of SNF expected in the repository. This needs to be projected for } \\
\text { different scenarios }\end{array}$ \\
\hline Glass compositions & $\begin{array}{l}\text { There are several options on glass type. An evaluation of properties, ease } \\
\text { of manufacture and cost is required }\end{array}$ \\
\hline \multicolumn{2}{|l|}{ Repository performance } \\
\hline Analysis of DUSCOBS & $\begin{array}{l}\text { Performance of DUSCOBS under repository conditions must be } \\
\text { evaluated as a function of glass properties. Most of the tools required } \\
\text { have been developed for repository analysis }\end{array}$ \\
\hline Glass testing & $\begin{array}{l}\text { Leach and isotopic exchange rates for glasses are required to confirm } \\
\text { particular glasses meet specifications }\end{array}$ \\
\hline \multicolumn{2}{|l|}{ Operations } \\
\hline Glass filling & $\begin{array}{l}\text { Demonstration of how to fill an MPC with glass beads is needed to } \\
\text { determine appropriate procedures }\end{array}$ \\
\hline \multicolumn{2}{|l|}{ Transport/storage cask } \\
\hline Design & $\begin{array}{l}\text { Design evaluations and tradeoffs are necessary to optimize the transport } \\
\text { and storage cask design. This includes addressing burnup credit and other } \\
\text { regulatory issues }\end{array}$ \\
\hline Economics & Self explanatory \\
\hline System optimization & $\begin{array}{l}\text { The glass composition and other design variables can be chosen to } \\
\text { maximize particular benefits to address those areas most needing } \\
\text { improvement in performance. There are tradeoffs }\end{array}$ \\
\hline
\end{tabular}




\section{INTERNAL DISTRIBUTION}

1-5. R. C. Ashline

6. E. C. Beahm

7. J. M. Begovich

8-12. K. W. Childs

13. H. E. Clark

14. J. A. Clinard

15. R. N. Collier

16. A. G. Croff

17. N. H. Cutshall

18. S. B. Derrington

19-23. M. D. Dehart

24. L. R. Dole

25. K. R. Elam

26-30. C. W. Forsberg

31. T. M. Gilliam

32. S. R. Greene

33. M. J. Haire

34. R. D. Hatcher

35. D. M. Hetrick

36. A. S. Icenhour

37. H. T. Kerr

38. J. A. Klein

39. D. C. Kocher
40. A. M. Krichinsky

41. M. A. Kuliasha

42. S. B. Ludwig

43. A. P. Malinauskas

44. L. E. McNeese

45. G. E. Michaels

46. J. P. Nichols

47. C. V. Parks

48-52. R. B. Pope

53. R. T. Primm

54. D. E. Reichle

55. J. W. Roddy

56. L. B. Shappert

57. K. D. Snyder

58. S. N. Storch

59-63. J. S. Tang

64. R. M. Westfall

65-66. Central Research Library

67-68. Laboratory Records

69. Laboratory Records-RC

70. ORNL Y-12 Technical Library

71. Document Reference Section

72. ORNL Patent Section

\section{EXTERNAL DISTRIBUTION}

73-74. Office of Scientific and Technical Information, P.O. Box 62, Oak Ridge, Tennessee 37831. 